\title{
Contemporary molecular barium chemistry
}

Peter M. Chapple and Yann Sarazin*

\author{
P. M. Chapple, Dr. Y. Sarazin \\ Univ Rennes, CNRS, ISCR-UMR 6226, 35000 Rennes (France) \\ E-mail: yann.sarazin@univ-rennes1.fr \\ Webpage: https://iscr.univ-rennes1.fr/yann-sarazin
}

\begin{abstract}
Driven by the many potential applications as a molecular catalyst for a range of metal-promoted transformations, the quest for well-defined, soluble and reactive complexes of barium has attracted substantial interest in the past decade. While it has long been overlooked, barium is now one of the hotly debated metals in main group chemistry. The present review surveys the main achievements of the last 10 years in the molecular chemistry of barium, presenting along the way the key synthetic strategies that have been implemented successfully to address the specificities of barium chemistry. This includes ligand design and non-covalent interactions. The performances of barium complexes as homogeneous catalysts for the most prominent reactions mediated by alkaline-earth metals (hydroelementations and heterodehydrocouplings) are reviewed in conjunction with those obtained with somewhat more common calcium or strontium catalysts.
\end{abstract}

Keywords: barium - molecular complexes - synthetic strategies - homogenous catalysis 


\section{Introduction}

\section{Aims and scope}

The last two decades have seen a surge of interest in the large alkaline-earth metals $(\mathrm{Ae}=\mathrm{Ca}, \mathrm{Sr}, \mathrm{Ba})$, mainly for their use in a range of homogeneous catalysis reactions. Although the primary focus of much of the literature has been on the molecular chemistry of calcium due to its abundancy and global availability, low toxicity and low cost, many of these catalytic applications are actually catalysed more effectively by strontium and, especially, barium catalysts. In fact, until recently, barium had remained somewhat on the side compared to the other alkaline earths in terms of molecular synthetic chemistry; yet, it is not without its merits, and it is now slowly gaining the recognition one may think it rightly deserves.

This review aims to highlight some of the subtle differences between the chemistry of barium and that of the 'lighter' heavy alkaline earths, including problems specific to barium complexes, as well as issues attributed to all of the large alkaline earths. There will be a focus on how these problems have been mitigated in the recent literature, leading to a range of novel barium complexes and exciting reactivity, as well as a review of the catalytic transformations involving molecular barium catalysts with a comparison to using the lighter congeners. For more general information on the molecular chemistry of the large alkaline earths, the reader is directed to previous reviews on heavy Grignard chemistry, the use of molecular alkaline-earth reagents for synthesis, and overviews of alkaline-earth mediated homogenous catalysis. ${ }^{[1-6]}$ Barium has also been used for many other non-catalytic applications, including high temperature superconductors, ferroelectric materials and non-linear optics. ${ }^{[7]}$ These applications often require deposition as thin films; as such, metal-organic chemical vapour deposition and atomic layer deposition using volatile Ba precursors has been an active field of research. ${ }^{[8-11]}$ However, this content falls outside the period of interest covered here, and will not be discussed.

\section{Specifity of barium organometallic chemistry}

Although barium species are often more active in catalytic manifolds compared to calcium analogues, unlike $\mathrm{Ca}$ it is known to be toxic, even in low doses. ${ }^{[12-13]}$ Its toxicity arises from blocking potassium channels resulting in an increase in intracellular potassium and extracellular hypokalaemia; however, it is not carcinogenic and does not bioaccumulate. ${ }^{[14-15]}$ Bonding in the heavier alkaline earths becomes more ionic as the group is descended due to the increasing electropositivity of the metals. The increasing ionic nature of the bonding for the group 2 elements has been quantified by charge calculations for the molecules $\mathrm{AeMe}_{2}(\mathrm{Be}-\mathrm{C}=74 \%, \mathrm{Mg}-\mathrm{C}=77 \%, \mathrm{Ca}-\mathrm{C}=87 \%, \mathrm{Sr}-\mathrm{C}=91 \%, \mathrm{Ba}-\mathrm{C}=94 \%) .{ }^{[16]}$ Two key elements are worth noting here: first, the heavier Ae metals are significantly more ionic than the much more researched magnesium, and secondly that for $\mathrm{Ba}$, non-directional ionicity dominates bonding, with only a negligible covalent contribution. The increasing ionic radii $\left(\mathrm{Ca}^{2+}=1.00 \AA, \mathrm{Sr}^{2+}=1.18 \AA, \mathrm{Ba}^{2+}=1.35 \AA\right)$ and 
decreasing electronegativity $(\mathrm{Ca}=1.00, \mathrm{Sr}=0.95, \mathrm{Ba}=0.89)^{[17]}$ as the group is descended induce a decreasing charge density and increasing polarisability from $\mathrm{Ca}$ to $\mathrm{Ba}$. This results in the primary difference between barium and calcium; while the latter is usually a better Lewis acid and therefore more suitable for Lewis acid catalysis, barium's more pronounced ionic character and longer, weaker bonds make it overall more suitable for $\sigma$-bond metathesis and insertion-based catalysis. However, weaker, more ionic bonds also result in the major problem plaguing the solution chemistry of the large Ae metals, Schlenk-type ligand redistribution. The strong ionic nature of the bonding can also result in poor solubility in conventional apolar organic solvents such as aliphatic hydrocarbons, benzene and toluene, meaning reactions are often required to be run in ethereal solvents that can coordinate in a donor fashion to the metal centre. This in turn can reduce the reactivity of the complex, as many coordinating solvents are non-innocent and alter the steric and electronic features of the coordination sphere. Besides, the large size of barium also often leads to the formation of aggregates, which further reduces solubility.

\section{Schlenk redistribution}

Although ligand redistribution affects all the large alkaline earths and even magnesium, the properties of the metal make it a much greater problem for barium. For many heteroleptic complexes, uncontrolled ligand scrambling generates ill-defined mixtures of species (Figure 1). To overcome this reshuffling, a bulky, monoanionic and multidentate ancillary ligand $\{L\}^{-}$is often used that can kinetically stabilise heteroleptic complexes of composition $\left[\{\mathrm{L}\} \mathrm{AeX} \cdot(\text { solvent })_{\mathrm{n}}\right]$, where $\mathrm{X}^{-}$is a reactive coligand, by taking advantage of steric and/or electronic factors. The ancillary ligand can also help control the coordination sphere of the metal, influencing catalyst properties and lifetime, as well as controlling solubility. The use of suitable ligands has allowed access to a range of alkaline earth complexes with unique Ae-X bonds where $\mathrm{X}^{-}$is a negatively charged reactive group such as $\left(\mathrm{Me}_{3} \mathrm{Si}\right)_{2} \mathrm{~N}^{-},\left(\mathrm{Me}_{3} \mathrm{Si}\right)_{2} \mathrm{CH}^{-}, \mathrm{Ph}_{2} \mathrm{P}^{-}$or $\mathrm{H}^{-}$.

2

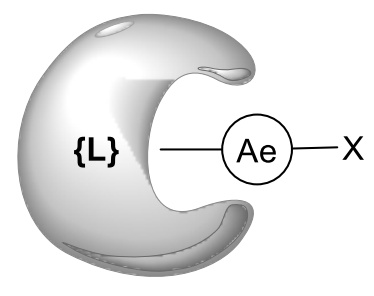

$2\{\mathrm{~L}\} A e X$

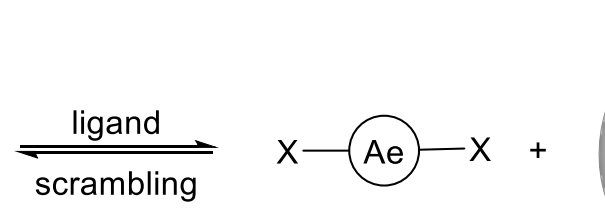

$\operatorname{Ae}(\mathrm{X})_{2}$

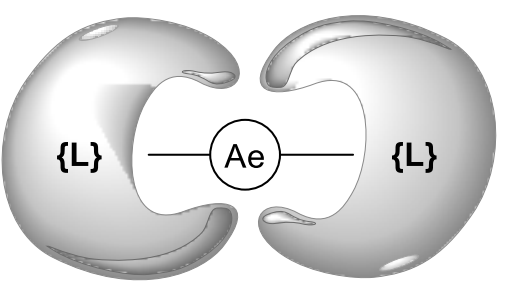

$\operatorname{Ae}\{L\}_{2}$

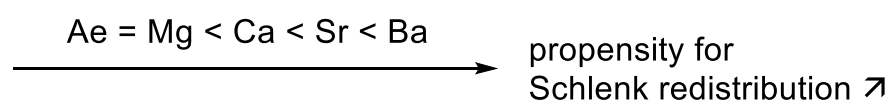

Figure 1. Ligand scrambling in alkaline-earth complexes; note that the different species may be solvated. 
The difficulty of barium ligand scrambling is best highlighted with the ubiquitous nitrogen-based multidentate $\beta$-diketiminate ligand $\mathrm{CH}[\mathrm{C}(\mathrm{Me}) \mathrm{N}-\mathrm{DiPP}]_{2}{ }^{-}(\mathrm{DiPP}=2,6$-di-isopropylphenyl $)$, here abbreviated as $\mathrm{BDI}^{\mathrm{DiPP}}$. This ligand has been used to suppress Schlenk redistribution for calcium chemistry, allowing access to many unprecedented compounds, including Ca-hydride, alkyl and fluoride species. ${ }^{[18-20]}$ However, when used to stabilise heteroleptic barium complexes, the ligand quickly redistributes to an equilibrium mixture with the homoleptic species. ${ }^{[21]}$ Schlenk redistribution can lead to the formation of polymeric aggregates or cluster compounds with low solubility, a problem that is especially irksome in homogenous catalysis, as it inhibits the collection of accurate kinetic data and makes gathering data to assist in the understanding of the catalytic mechanisms problematic.

\section{On steric considerations}

The large ionic radius of the $\mathrm{Ba}^{2+}$ cation means that reaching coordinative saturation, which may be required to prevent the formation of insoluble aggregates or coordination polymers, can be difficult. However, seeking steric oversaturation is not a viable option, as it will lead to the opposite problem; the complex become unreactive due to the lack of access to the metal centre. The main difficulty of barium chemistry is therefore balancing the demands of kinetic stabilisation, while still leaving the complex suitably exposed for reactivity, catalysis or sheer inorganic derivatisation. The following sections will give an overview of the methods implemented by organometallic chemists, from the introduction of secondary interactions to the design of sophisticated ligands, to warrant the stability of barium complexes without impeding their reactivity, which were later used as homogeneous (pre)catalysts. The survey begins with non-covalent interactions since, although they are obviously less significant than primary interactions and ligand design, they constitute a structural pattern often encountered in a broad range of different types of complexes.

\section{A useful secondary tool: stabilisation through non-covalent interactions}

The large size and low electronegativity of barium results in difficulties to suitably saturate both the electronic and steric requirements of the metal, which if not satisfactorily met can result in formation of aggregates or polymeric materials. The low solubility and slow reactivity in organic solvents of these types of compounds make them unsuitable for a range of chemical applications. One way to suppress aggregation and generate low-nuclearity discrete complexes is by using secondary interactions. Secondary (also called non-covalent) interactions are described here as interactions between the electron-deficient barium centre and a charge-neutral atom (or group of atoms) that can donate electron density that assists to stabilise the metal. They are different to primary interactions, which are the main interactions between the metal and its ligand(s) or coligand(s), such as formal $\sigma$ or dative bonds. Non-covalent interactions have been described and surveyed elsewhere; ${ }^{[5,22-23]}$ this review will only cover the literature of the last ten years. 
Three main categories of secondary interactions have been commonly exploited to produce stable barium complexes: $\mathrm{Ba} \cdots \mathrm{C}(\pi)$, Ba $\cdots \mathrm{F}$ and anagostic interactions that encompass $\mathrm{Ba} \cdots \mathrm{H}-\mathrm{C},{ }^{[24-25]} \mathrm{Ba} \cdots \mathrm{Me}-$ $\mathrm{Si}^{[26-29]}$ and $\mathrm{Ba} \cdot \mathrm{H}_{-} \mathrm{Si}^{[5,30]}$ contacts. This often entails the utilisation of specific coligands, e.g. the tetramethyldisilazide $\mathrm{N}\left(\mathrm{SiMe}_{2} \mathrm{H}\right)_{2}{ }^{-}$, or the design of ancillary ligands that contain flanking aromatic groups or fluorine atoms. These secondary interactions, which are electrostatic in essence, involve the doubly charged $\mathrm{Ba}^{2+}$ cation and a localised dipole through metal-induced polarisation. Their strength is highly relative. It depends considerably on the primary interactions within the compound, as secondary interactions play a more important role when primary bonding is weaker. The type of secondary interactions can impact the solid-state structure of the compound. Quantification of the strength of these interactions can be difficult and sometimes arbitrary, as geometry distortion, bond length relative to the sum of the van der Waals radii, literature convention and computational and semi-empirical methods (such as bond valence sum analysis) are all used to qualify secondary interactions. ${ }^{[31]}$

\section{$\operatorname{Ba}-\mathbf{C}(\pi)$ interactions}

Electronic rich aromatic molecules tend to bind easily to barium, the largest and softest of the $\mathrm{Ae}^{2+}$ cations. Due to the tendency for barium complexes to coordinate aromatic solvents, there are a reasonable number of cases of stabilising $\mathrm{Ba} \cdots \mathrm{C}(\pi)$ secondary interactions through coordination of benzene or toluene in the literature. Such an example is the peralkylated barium gallate $\left[\mathrm{Ba}\left(\mathrm{GaEt}_{4}\right)_{2} \cdot\right.$ toluene $_{2}$, where the Ba-centroid distances are 3.0067(3) and 3.0244(3) $\AA{ }^{[32]}$ Another notable recent case is $\left[\mathrm{Ba}_{7} \mathrm{H}_{7}\left\{\mathrm{~N}\left(\mathrm{SiMe}_{3}\right)_{2}\right\}_{7} \cdot\left(\mathrm{C}_{6} \mathrm{H}_{6}\right)_{2}\right]$, the first soluble barium-hydride forming a cluster, where two of the barium atoms are face-capped by loosely $\eta^{6}$-coordinated benzene molecules at distances of 3.634(1) $\AA^{\left[{ }^{[33]}\right.}$ However, there are far fewer examples of intramolecular $\mathrm{Ba} \cdots \mathrm{C}(\pi)$ secondary interactions where the ligand offers some stabilisation through $\mathrm{Ba} \cdots \mathrm{C}(\pi)$ contacts. These interactions are generally characterised using solid-state XRD data, and there is a consideration often made in the literature, that for a secondary interaction to be deemed significant, the Ba-C $(\pi)$ interatomic distance must be below $3.48 \AA \AA^{\left[{ }^{[2]}\right.}$ The triazenide $\left\{\left(2,6-\mathrm{Mes}_{2}-\mathrm{C}_{6} \mathrm{H}_{3}\right) \mathrm{NNN}(2-\mathrm{Trip}-\right.$ $\left.\mathrm{C}_{6} \mathrm{H}_{4}\right\}^{-}($Trip $=2,4,6$ triisopropylphenyl; Mes = mesityl $)$ has yielded [ $\left\{\left(2,6-\mathrm{Mes}_{2}-\mathrm{C}_{6} \mathrm{H}_{3}\right) \mathrm{NNN}(2-\right.$ Trip$\left.\left.\mathrm{C}_{6} \mathrm{H}_{4}\right\} \mathrm{Ba}\left(\mathrm{C}_{6} \mathrm{~F}_{5}\right)\right]$, which includes $\eta^{5} \pi$-arene interactions stabilising the metal centre (Figure 2, left). ${ }^{[34 a]}$ The $\mathrm{Ba} \cdots \mathrm{C}(\pi)$ interatomic distances in the range 3.286(5)-3.430(4) $\AA$ are lower than the sum of the van der Waals radii. Interestingly, these $\pi$-arene interactions compete with thf coordination, resulting in a solventfree complex even though the synthesis occurred in thf solvent. The homoleptic complex using the same ligand has also been reported, and also has solid-state $\pi$-arene interactions from the two mesityl groups in an $\eta^{6}$ fashion, with $\mathrm{Ba}-\mathrm{C}(\pi)$ distances between 3.312(5) and 3.424(5) $\AA$ ). ${ }^{[34 \mathrm{~b}]}$ The homoleptic $\left[\mathrm{Ba}\left\{{ }^{\mathrm{Mes}} \mathrm{N}\left\{\mathrm{C}\left(\mathrm{NCy}_{2}\right)\right\} \mathrm{N}^{\mathrm{Mes}}\right\}_{2}\right]$, a complex supported by two guanidinate ligands, also shows stabilising $\pi$ arene interactions (Figure 2, centre) ${ }^{[35]}$ The two $\eta^{6}$-contacts with the flanking mesityl groups have $\mathrm{Ba} \cdots \mathrm{C}(\pi)$ 
interatomic distances between 3.138(2)-3.337(3) $\AA$. Another case of $\eta^{6}-\pi$-arene interaction $(\mathrm{Ba}-\mathrm{C}(\pi)=$ 2.996(5)-3.243(6) $\AA$ ) is found in the tris(pyrazolyl)borate [ $\left.\left\{\mathrm{Tp}^{\mathrm{Ad}, \mathrm{PPr}}\right\} \mathrm{Ba}\left(\eta^{6}-\mathrm{Ph}\right) \mathrm{C}(\mathrm{Ph}) \mathrm{Me}\right]$, the product of the reaction between $\left[\left\{\mathrm{Tp}^{\mathrm{Ad}, i \mathrm{Pr}}\right\} \mathrm{Ba}(\mu-\mathrm{H})\right]_{2}$ and diphenylethylene, although due to electron delocalisation there is an argument to consider this interaction as primary instead of secondary (Figure 2, right). ${ }^{[36]}$

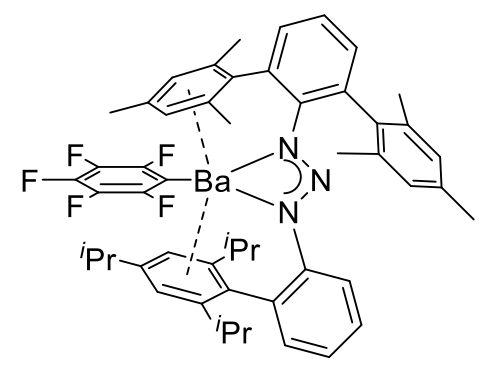

$\left[\left\{\left(2,6-\mathrm{Mes}_{2}-\mathrm{C}_{6} \mathrm{H}_{3}\right) \mathrm{NNN}\left(2-\right.\right.\right.$ Trip- $\left.\left._{6} \mathrm{H}_{4}\right\} \mathrm{Ba}\left(\mathrm{C}_{6} \mathrm{~F}_{5}\right)\right]$

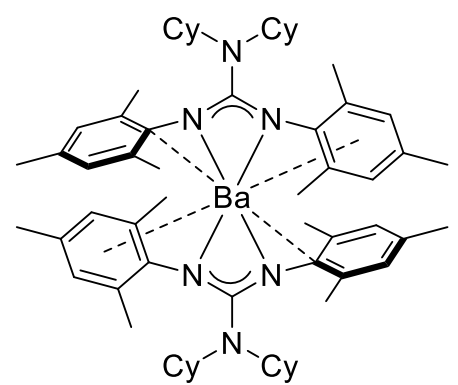

$\left[\mathrm{Ba}\left\{{ }^{\mathrm{Mes}} \mathrm{N}\left\{\mathrm{C}\left(\mathrm{NCy}_{2}\right)\right\} \mathrm{N}^{\mathrm{Mes}}\right\}_{2}\right]$

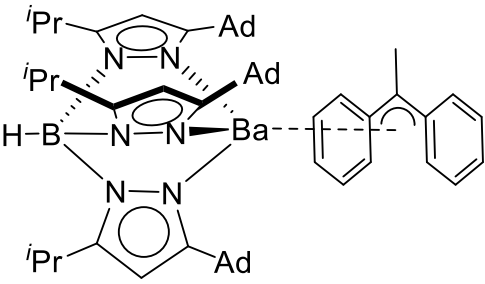

$\left[\left\{\mathrm{Tp}^{\mathrm{Ad}, \mathrm{Pr}}\right\} \mathrm{Ba}\left(f \AA^{6}-\mathrm{Ph}\right) \mathrm{C}(\mathrm{Ph}) \mathrm{Me}\right]$

Figure 2. Barium complexes presenting intramolecular $\mathrm{Ba} \cdots \mathrm{C}(\pi)$ interactions. ${ }^{[34-36]} \mathrm{Ad}=1$-adamantyl, Mes $=$ mesityl, $\mathrm{Cy}=$ cyclohexyl.

\section{Ba-F interactions}

In the past, fluorinated ligands were seldom used to stabilise alkaline-earth complexes as potential C-F activation to give the homoleptic Ae-fluoride (favourable due to their high lattice energies) was viewed as a synthetic limitation. However, the value of fluorinated ligands is now beginning to be appreciated.

The polymeric $\left[\mathrm{Ba}\left\{\mathrm{N}(\mathrm{H})-2,6-\mathrm{F}_{2} \mathrm{C}_{6} \mathrm{H}_{3}\right\}_{2} \cdot(\mathrm{thf})_{2}\right]_{\infty}$ is one of the earlier structurally characterised barium compounds presenting Ba-F interactions. ${ }^{[37]}$ It was synthesised from the metathesis reaction between $\mathrm{BaI}_{2}$ and $\left[\mathrm{K}\left(\mathrm{N}(\mathrm{H})-2,6-\mathrm{F}_{2} \mathrm{C}_{6} \mathrm{H}_{3}\right)\right]$ in thf. The XRD data reveals a one-dimensional polymer in which $\mathrm{Ba}$ atoms are six-coordinate, with two bridging amides between consecutive metals. Each barium atom has two

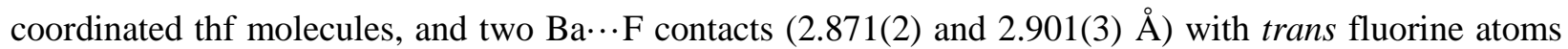
from the bridging anilides. The polymeric structure highlights the large electronic and steric demands of barium, as with calcium and strontium, the dimeric molecular complexes $\left[\mathrm{Ca}_{2}\left\{\mathrm{~N}(\mathrm{H})-2,6-\mathrm{F}_{2} \mathrm{C}_{6} \mathrm{H}_{3}\right\}_{4} \cdot(\mathrm{thf})_{5}\right]$ and $\left[\mathrm{Sr}_{2}\left[\mathrm{~N}(\mathrm{H})-2,6-\mathrm{F}_{2} \mathrm{C}_{6} \mathrm{H}_{3}\right\}_{3} \mathrm{I} \cdot(\text { thf })_{6}\right]$, the latter with a terminal iodide, were obtained (Figure 3). 


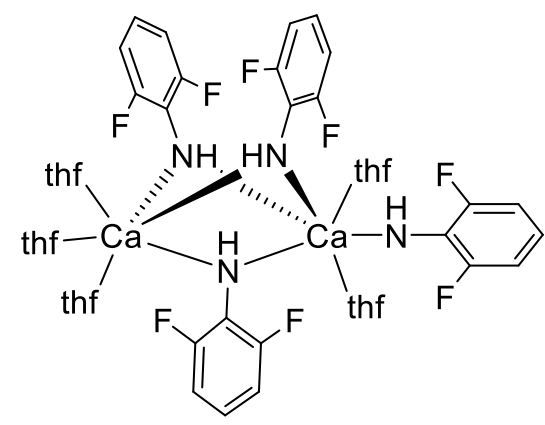

Ca - dimeric

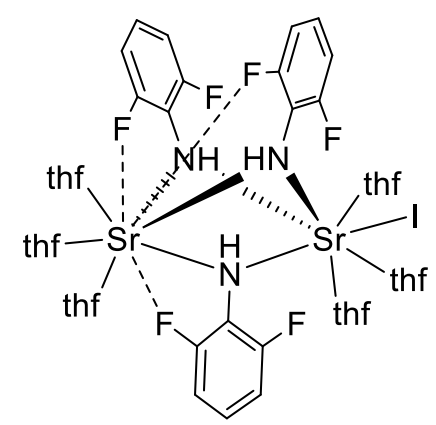

Sr - dinuclear

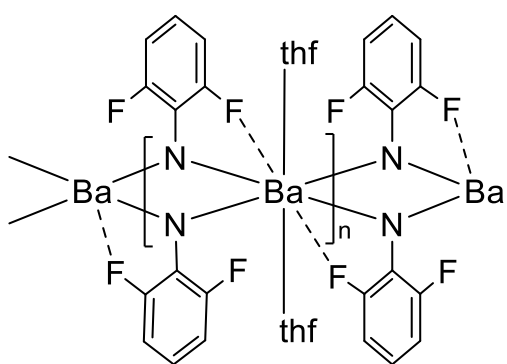

$\mathrm{Ba}$ - polymeric

Figure 3. Ae complexes with Ae $\cdots$ F interactions using the 2,6 difluoroaniline ligand. ${ }^{[37]}$

The homoleptic bis(hydridoborate) $\left[\mathrm{Ba}\left\{\mathrm{HB}\left(\mathrm{C}_{6} \mathrm{~F}_{5}\right)_{3}\right\}_{2} \cdot(\text { thf })_{4}\right]$ has also been shown to possess stabilising Ba $\cdots F$ contacts in the solid state (Figure 4) ${ }^{[38]}$ The compound, synthesised from the potassium borate and $\mathrm{BaI}_{2}$ in thf, was monometallic with a coordination number of four at Ba with coordinating thf molecules, further completed by two Ba $\cdots \mathrm{H}(2.83(3) \AA)$ anagostic interactions and four Ba $\cdots \mathrm{F}(2.8228(19)-2.8386(17)$ $\AA$ A) contacts. The dimeric homoleptic barium complex $\left[\mathrm{Ba}\left\{\mu-\mathrm{N}\left(\mathrm{C}_{6} \mathrm{~F}_{5}\right)_{2}\right\}\left\{\mathrm{N}\left(\mathrm{C}_{6} \mathrm{~F}_{5}\right)_{2}\right\} \cdot \text { (toluene) }\right]_{2}$ has also been reported via the protonolysis reaction between $\left[\mathrm{Ba}\left\{\mu-\mathrm{N}\left(\mathrm{SiMe}_{3}\right)_{2}\right\}\left\{\mathrm{N}\left(\mathrm{SiMe}_{3}\right)_{2}\right\}\right]_{2}$ and $\mathrm{HN}\left(\mathrm{C}_{6} \mathrm{~F}_{5}\right)_{2}$ in toluene. ${ }^{[39]}$ Each Ba-atom has a formal coordination number of three consisting of two bridging and one terminal amides, and it also displays five stabilising $\mathrm{Ba} \cdots \mathrm{F}$ and one $\mathrm{Ba} \cdots \mathrm{C}(\pi)$ interaction $\left(\mathrm{Ba}-\mathrm{C}_{\text {toluene }}=\right.$ 3.287(5)-3.436(6) A) from a solvating toluene molecule. The Ba $\cdots$ F interactions range between 2.740(3)-

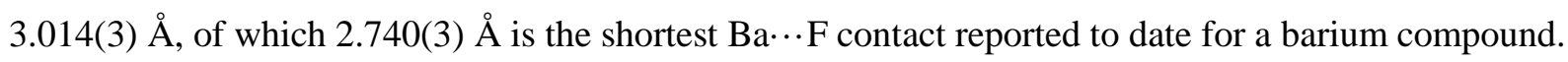

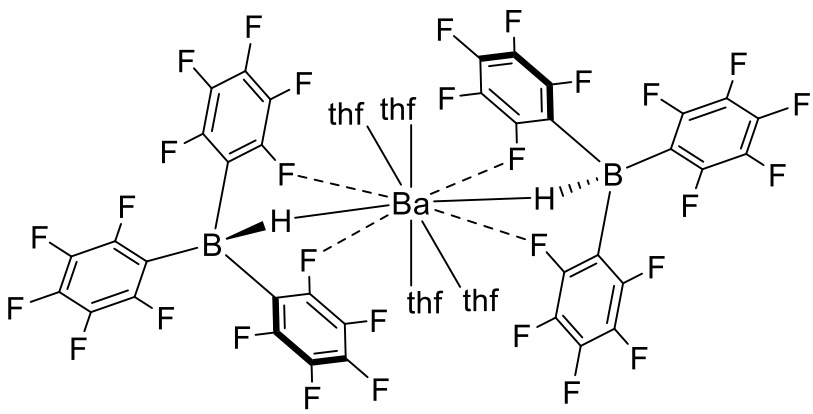

$\left[\mathrm{Ba}\left\{\mathrm{HB}\left(\mathrm{C}_{6} \mathrm{~F}_{5}\right)_{3}\right\}_{2} \cdot(\text { thf })_{4}\right]$

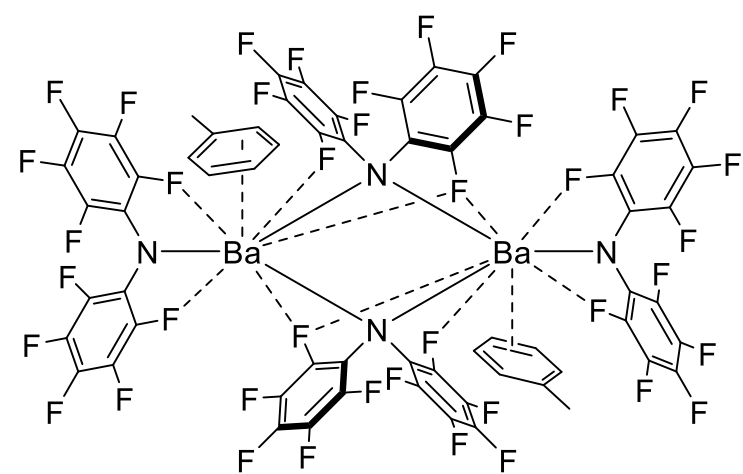

$\left[\mathrm{Ba}\left\{\mu-\mathrm{N}\left(\mathrm{C}_{6} \mathrm{~F}_{5}\right)_{2}\right\}\left\{\mathrm{N}\left(\mathrm{C}_{6} \mathrm{~F}_{5}\right)_{2}\right\} \cdot(\text { toluene })\right]_{2}$

Figure 4. Homoleptic barium complexes supported by non-covalent $\mathrm{Ba} \cdots \mathrm{F}$ interactions

\section{Anagostic interactions}

The large and soft $\mathrm{Ba}^{2+}$ cation can also have strong $\mathrm{Ba} \cdots \mathrm{H}-\mathrm{C}$ or $\mathrm{Ba} \cdots \mathrm{H}-\mathrm{Si}$ agostic interactions. However as the original definition for agostic bonding is for a three-centre-two-electron $\mathrm{M}-\mathrm{H}-\mathrm{C}$ bond in transition 
metals that includes $\mathrm{d}(\mathrm{M}) \rightarrow \sigma^{*}(\mathrm{C}-\mathrm{H})$ back-donation, the definition does not technically apply for any $s$ block metals due to their $\mathrm{d}^{0}$ electronic configurations. ${ }^{[5]}$ Instead, the term 'anagostic' has been branded for these metals to describe the polarisation of the $\mathrm{C}-\mathrm{H}$ or $\mathrm{Si}-\mathrm{CH}_{3}$ bonds by the electropositive $\mathrm{Ae}^{2+}$ cation, resulting in an attractive electrostatic attractions of the type $\mathrm{Ae}^{2+} \ldots \mathrm{Me}^{\delta-}-\mathrm{Si}^{\delta+}$ or $\mathrm{Ae}^{2+} \ldots \mathrm{H}^{\delta-}-\mathrm{C}^{\delta+} \cdot{ }^{[40]}$ Unlike agostic interactions in the transition metal complexes, anagostic interactions do not alter the bonding pattern geometry. It should be noted that these interactions are often hard to validate due to the high uncertainty in locating hydrogen atoms using X-ray diffraction crystallography, although solid-state data are used in conjunction with ${ }^{1} \mathrm{H}$ NMR data in some situations, as can FTIR spectroscopy.

$\beta$-Si-H anagostic interactions have been used in recent years to stabilise homoleptic and heteroleptic barium amide complexes. The tetradisilazide ligand $\mathrm{N}\left(\mathrm{SiMe}_{2} \mathrm{H}\right)_{2}{ }^{-}$has been used since the 1990s to give compounds with unusual structure and reactivity. ${ }^{[11]}$ The bis(amide) $\left[\mathrm{Ba}\left\{\mathrm{N}\left(\mathrm{SiMe}_{2} \mathrm{H}\right)_{2}\right\}_{2}\right]_{n}$ was synthesised via the transamination of $\left[\mathrm{Ba}\left\{\left(\mathrm{N}\left(\mathrm{SiMe}_{3}\right)_{2}\right\}_{2} \cdot(\text { thf })_{2}\right]\right.$ with the free amine $\mathrm{H}\left\{\mathrm{N}\left(\mathrm{SiMe}_{2} \mathrm{H}\right)_{2}\right\}\left(p \mathrm{~K}_{\mathrm{a}}(\mathrm{thf})\right.$ : $\left.\mathrm{HN}\left(\mathrm{SiMe}_{3}\right)_{2}, 25.8 ; \mathrm{H}\left\{\mathrm{N}\left(\mathrm{SiMe}_{2} \mathrm{H}\right)_{2}\right\} 22.6\right) .^{[42]}\left[\mathrm{Ba}\left\{\mathrm{N}\left(\mathrm{SiMe}_{2} \mathrm{H}\right)_{2}\right\}_{2}\right]_{n}$ can be isolated free of thf, even when synthesised in thf (an uncommon phenomena). However, as the compound is only soluble in thf, characterisation of the thf-free complex by XRD proved impossible; only the molecular structures of the six-coordinate solvate $\left[\mathrm{Ba}\left\{\mathrm{N}\left(\mathrm{SiMe}_{2} \mathrm{H}\right)_{2}\right\}_{2} \cdot(\text { thf })_{4}\right]$ and that of the five-coordinate phenanthroline adduct $\left[\mathrm{Ba}\left\{\mathrm{N}\left(\mathrm{SiMe}_{2} \mathrm{H}\right)_{2}\right\}_{2} \cdot \text { phen }\right]_{2}$ could be elucidated. ${ }^{[32]}$ The latter exhibits identifiable intramolecular $\beta-\mathrm{Si}-\mathrm{H} \cdots \mathrm{Ba}$ anagostic interactions in the solid state, but $\left[\mathrm{Ba}\left\{\mathrm{N}\left(\mathrm{SiMe}_{2} \mathrm{H}\right)_{2}\right\}_{2} \cdot(\text { thf })_{4}\right]$ does not. Subsequent protonolysis of $\left[\mathrm{Ba}\left\{\mathrm{N}\left(\mathrm{SiMe}_{2} \mathrm{H}\right)_{2}\right\}_{2}\right]_{n}$ with the aminoetherphenol 2-\{(1,4,7,10-tetraoxa-13-aza-cyclopentadecan-13-yl)methyl $\}-4,6$-di-tert-butyl-phenol $\left(=\left\{\mathrm{LO}^{\text {crown }}\right\} \mathrm{H}\right)$ afforded the heteroleptic $\left[\left\{\mathrm{LO}^{\text {crown }}\right\} \mathrm{BaN}(\mathrm{SiMe} 2 \mathrm{H})_{2}\right]$ as a kinetically stable complex; it acted as a precatalyst for the ring opening polymerisation (ROP) of cyclic esters (Figure 5). ${ }^{[42]}$ While $\left[\left\{\mathrm{LO}^{\text {crown }}\right\} \mathrm{BaN}\left(\mathrm{SiMe}_{2} \mathrm{H}\right)_{2}\right]$ did not undergo ligand redistribution, the congeneric hexamethyldisilazide $\left[\left\{\mathrm{LO}^{\text {crown }}\right\} \mathrm{BaN}\left(\mathrm{SiMe}_{3}\right)_{2}\right]$ was not stable, a difference attributed to the stabilising role of the $\mathrm{Si}-\mathrm{H}$ anagostic contact. ${ }^{1} J_{\mathrm{Si}-\mathrm{H}}$ coupling constants were used to gauge the strength of this interaction; the resulting value of $160 \mathrm{~Hz}$ indicated it was a weak to mild contact. However, due to competing solvent effects, the coupling values may not reflect the true strength of the interaction in solution as they only give access to time-averaged values. ${ }^{[41]}$ The presence of $\beta-\mathrm{Si}-\mathrm{H}$ anagostic interactions is best established by a combination of XRD and FTIR solid-state data, and NMR spectroscopy in solution. ${ }^{[23]}$ This synthetic device has also been used to prepare solution-stable and efficient barium precatalysts for hydroelementation reactions (vide infra). For instance, the $\beta$-diketiminate $\left[\left\{\mathrm{BDI}^{\mathrm{DiPP}}\right\} \mathrm{BaN}\left(\mathrm{SiMe}_{2} \mathrm{H}\right)_{2} \cdot(\text { thf })_{2}\right]$, a complex which unlike its parent $\left[\left\{\mathrm{BDI}^{\mathrm{DiPP}}\right\} \mathrm{BaN}\left(\mathrm{SiMe}_{3}\right)_{2} \cdot(\text { thf })_{2}\right]$ does not show signs of ligand scrambling in solution, ${ }^{[42]}$ performs well in the catalysis of the intermolecular hydroamination of styrenes, ${ }^{[43]}$ whereas $\left[\left\{\right.\right.$ Amid $\left.\left.^{\text {crown }}\right\} \mathrm{BaN}\left(\mathrm{SiMe}_{2} \mathrm{H}\right)_{2}\right]$ bearing a multidentate amidinate functionalised by an aza-crown-ether affords one of the most active hydrophosphination catalysts to date (Figure 5). ${ }^{[44]}$ Finally, the complex $\left[\mathrm{Ba}_{2} \mathrm{Li}_{2}\left\{\mu_{2-}\right.\right.$ 
$\left.\left.\mathrm{N}\left(\mathrm{SiMe}_{2} \mathrm{H}\right)_{2}\right\}_{6}\right]_{\infty}$ forms a one-dimensional coordination polymer in the solid state due to the presence of multiple $\mathrm{Ba} \cdots \mathrm{H}-\mathrm{Si}$ and $\mathrm{Li} \cdots \mathrm{H}-\mathrm{Si}$ anagostic interactions. ${ }^{[45]}$ Obtained by mixing $\left[\mathrm{Ba}\left\{\mathrm{N}\left(\mathrm{SiMe}_{2} \mathrm{H}\right)_{2}\right\}_{2}\right]_{n}$ and $\left[\mathrm{LiN}\left(\mathrm{SiMe}_{2} \mathrm{H}\right)_{2}\right]_{p}$, it is the first structurally authenticated heterobimetallic amide based on barium. Although only moderately basic, it can be related to the heterobimetallic main group "ate" compounds used for the deprotometalation of weak acids and dehalogenative functionalisation of aromatic substrates. ${ }^{[46]}$

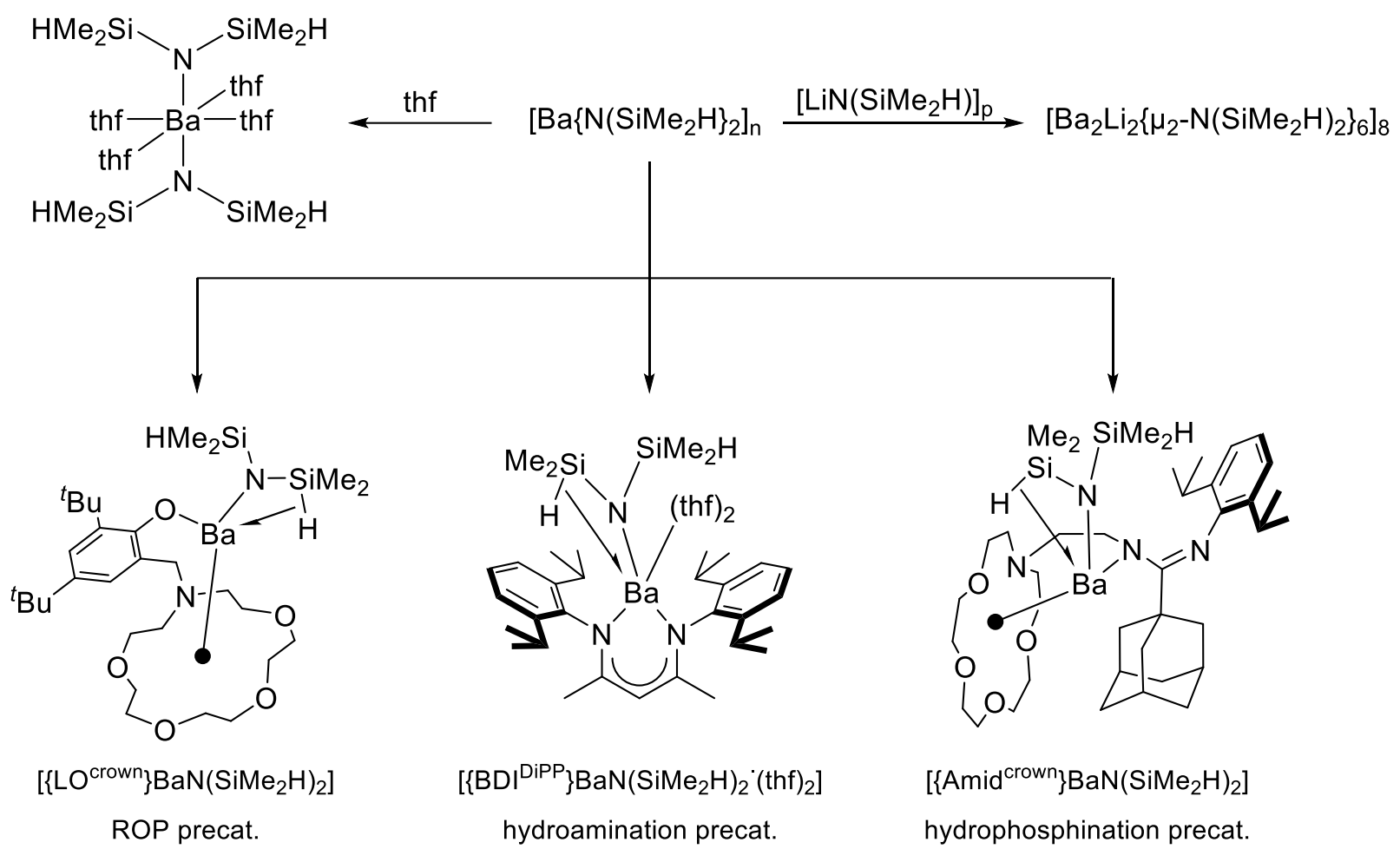

Figure 5. Selection of barium complexes stabilised by $\beta-\mathrm{Si}-\mathrm{H}$ anagostic interactions. ${ }^{[31,41-45]}$ Black dots indicate that all heteroatoms are metal-bound.

\section{Homoleptic Complexes}

The simplest way to overcome the Schlenk equilibrium is to remove it altogether. Homoleptic complexes feature a metal supported by two identical monoanionic ligands, i.e. $\left[\mathrm{Ba}(\mathrm{X})_{2}\right]$ or solvated analogues, and make up the bulk of reported barium compounds. They forgo the need for kinetic stabilisation to control the Schlenk equilibrium, making access to pure products relatively comfortable. However, small, nonstabilising ligands are still susceptible to the formation of agglomerates or larger polynuclear species.

The different methods available to synthesise homoleptic alkaline-earth complexes have been well reviewed ${ }^{[1-4]}$ and as such will not be covered here, but can generally be classified as either direct methods from elemental $\mathrm{Ba}^{0}$ (which may need to be 'activated' with liquid ammonia first), salt metathesis, transmetallation or deprotonation/protonolysis. Although early work usually involved $\mathrm{Ba}^{0}$, most complexes 
are now generated via salt metathesis from commercially available anhydrous $\mathrm{BaI}_{2}$ with prepared potassium salts. This offers the advantage that the desired compound can often easily be separated from the starting materials and KI by-product using non-polar organic solvents. It should be noted that care to get the correct stoichiometry of the reactants must be taken, as excess ratios will lead to the formation of bariate species. ${ }^{[47]}$

\section{Alkyl ligands}

The benzyl group has widely been used in organometallic chemistry as a highly basic ligand capable of readily undergoing protonolysis. As such, organometallic benzyl compounds are useful precursors (and catalysts) for synthesising a variety of catalysts and for introducing a range of other groups via protonolysis. The earliest report of the use of dibenzylbarium was the in-situ generation from stirring dibenzylmercury over a barium mirror, with the resulting dibenzylbarium shown to be capable of mediating the living anionic polymerisation of styrenes. ${ }^{[48]}$ The improved preparation of dibenzylbarium via ligand exchange between $\left[\mathrm{Ba}\left\{\mathrm{N}\left(\mathrm{SiMe}_{3}\right)_{2}\right\}_{2} \cdot(\text { thf })_{2}\right]$ (or $\left[\mathrm{Ba}\left\{\mathrm{OC}_{6} \mathrm{H}_{2}-2,4,6-{ }^{t} \mathrm{Bu}_{3}\right\}_{2}\right]$ ) with 2 equivalents of [ $\mathrm{LiCH}_{2} \mathrm{Ph}$. tmeda], was reported in 2000, though the solid structure data could not be obtained due to the low solubility of the compound in both organic and ethereal solvents. ${ }^{[49]}$ More recently it has been reported that the salt metathesis between anhydrous $\mathrm{BaI}_{2}$ and benzylpotassium in thf can generate dibenzylbarium (as well as the $\mathrm{Ca}$ and $\mathrm{Sr}$ analogues) suitable for single crystal XRD analysis. ${ }^{[50]}$ Part of the complexity of synthesising the dibenzylbarium via salt metathesis was due to the low solubility of the product in ethereal solvents, which precluded isolation from the inorganic salt coproducts. Hence, although reactions could simply be run overnight for the $\mathrm{Ca}$ and $\mathrm{Sr}$ benzyl analogues to reach completion, the lower solubility of the Ba complex meant overnight reactions precipitated dibenzylbarium, which was then inseparable from the salt byproduct. Reaction time was therefore limited to 1.5 hours, but the reported yield (48\%) may be low due to partial precipitation of the product before this time. The resulting crystalline compound of composition $\left[\mathrm{Ba}_{3}\left(\mathrm{CH}_{2} \mathrm{Ph}\right)_{6} \cdot(\text { thf })_{4}\right]$ was highly reactive, with a half-life in thf at room temperature of approximately 5 days; these crystals lose thf under vacuum to afford a solid of chemical composition $\left[\mathrm{Ba}\left(\mathrm{CH}_{2} \mathrm{Ph}\right)_{2} \cdot(\mathrm{thf})_{0.5}\right]$. X-ray diffraction data revealed an extended 2-D network of units in which there are two different environments, featuring the $\mathrm{Ba}(1)$ centre with 3 benzyl ligands and solvated by two thf molecules, and another unsolvated environment around $\mathrm{Ba}(2)$ with $\eta^{6}-\mathrm{Ph}$ interactions and two $\eta^{3}$ interactions with the carbanion and the ortho and ipso $\mathrm{C}$-atoms of the benzyl (Figure 6). The $\mathrm{Ba}-\mathrm{C}_{\text {carbanion }}$ bond distances of 2.963(2) to 3.091(2) $\AA$ are somewhat longer than in the homoleptic complex $\left[\mathrm{Ba}\left\{\mathrm{CH}\left(\mathrm{SiMe}_{3}\right)_{2}\right\}_{2} \cdot(\text { thf })_{3}\right]^{[51]}$ (2.827(3) and 2.879(3) $\AA$ ) and diphenylmethanide complexes $\left[\mathrm{Ba}\left(\mathrm{CHPh}_{2}\right)_{2} \cdot 18\right.$-crown-6] (3.081(3) $\AA$ ) and $\left[\mathrm{Ba}\left(\mathrm{CHPh}_{2}\right)_{2} \cdot(\mathrm{dme})_{2}\right]^{[52]}(2.902(4) \AA)$. 


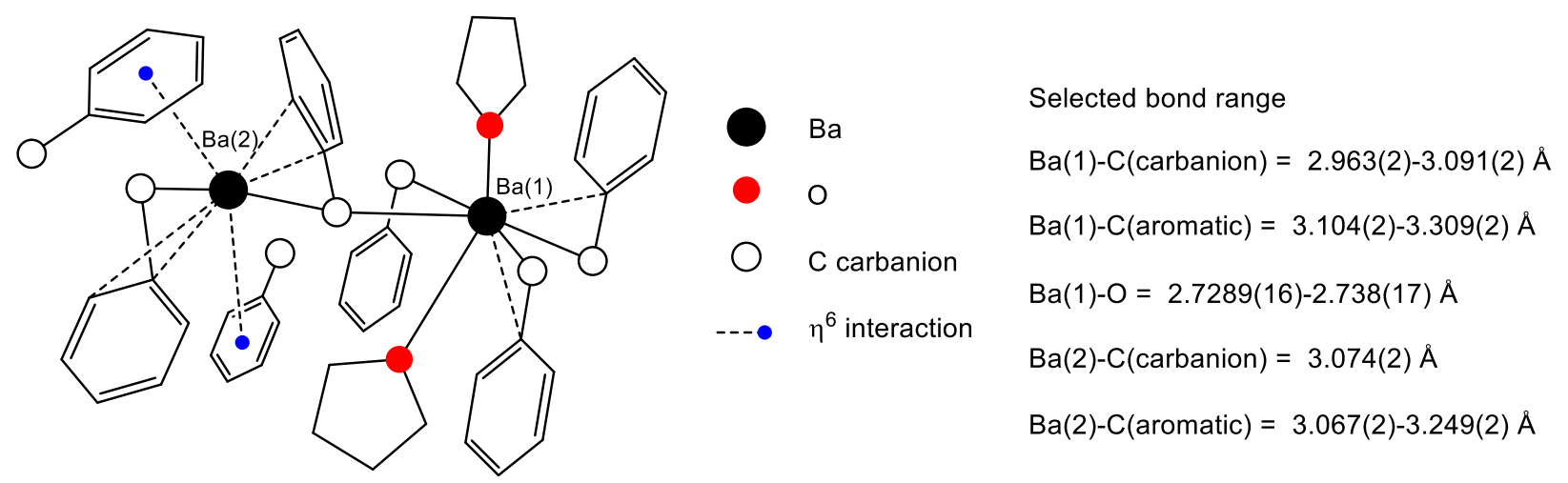

Figure 6. Asymmetric unit in the 2-D coordination polymer for crystalline $\left[\mathrm{Ba}_{3}\left(\mathrm{CH}_{2} \mathrm{Ph}\right)_{6} \cdot(\text { thf })_{4}\right] .{ }^{[50]}$

Due to the difficulty of its synthesis and its limited stability, dibenzylbarium has not found widespread applications, while the diphenylmethanide derivatives have seldom been used. The most popular alkyl ligand in barium chemistry is the bulky $\left\{\mathrm{CH}\left(\mathrm{SiMe}_{3}\right)_{2}\right\}^{-}$, which has been used to make both homoleptic and heteroleptic alkyl complexes. ${ }^{[51]}$ The dialkyl $\left[\mathrm{Ba}\left\{\mathrm{CH}\left(\mathrm{SiMe}_{3}\right)_{2}\right\}_{2} \cdot(\mathrm{thf})_{2}\right]$, which crystallises as the trisolvated $\left[\mathrm{Ba}\left\{\mathrm{CH}\left(\mathrm{SiMe}_{3}\right)_{2}\right\}_{2} \cdot(\text { thf })_{3}\right]$, is synthesised via salt metathesis from $\mathrm{BaI}_{2}$ and $\left[\mathrm{KCH}\left(\mathrm{SiMe}_{3}\right)_{2}\right]_{n}$ in thf; care must be paid to eliminate all traces of lithium salts from this product, best prepared from $\mathrm{H}_{2} \mathrm{C}\left(\mathrm{SiMe}_{3}\right)_{2}$, ${ }^{n} \mathrm{BuLi}$ and ${ }^{t} \mathrm{BuOK}$, in order to optimise the yields of pure Ba-alkyl. ${ }^{[53]}$ It is extremely soluble in non-polar solvents, and was the first example of $\sigma$-bonded Ba-dialkyl complex not supported by secondary interactions. The high basicity of the $\left\{\mathrm{CH}\left(\mathrm{SiMe}_{3}\right)_{2}\right\}^{-}$anion means the complex undergoes protonolysis with a range Brønsted acids and can be used for effective protonolysis/insertion synthetic strategies. It has been used to generate heteroleptic complexes such as the iminoanilide $\left[\left\{\operatorname{ImAn}^{\mathrm{DiPP}}\right\} \mathrm{BaCH}\left(\mathrm{SiMe}_{3}\right)_{2} \cdot(\operatorname{thf})_{2}\right]$, a hydroelementation precatalyst, ${ }^{[54]}$ and the sterically congested $\mathrm{Cp}$-derivative $\left[\left\{\mathrm{Cp}^{\mathrm{Ar}}\right\} \mathrm{BaCH}\left(\mathrm{SiMe}_{3}\right)_{2} \cdot(\mathrm{thf})_{2}\right]$, where $\mathrm{Ar}{ }^{\prime}=2,4,6-{ }^{i} \mathrm{Pr}_{3}-\mathrm{C}_{6} \mathrm{H}_{2}$, which itself was later used to prepare a molecular Ba-hydride (Figure 7). ${ }^{[55]}$

Other Ba-alkyl compounds include the perethylated barium aluminate $\left[\mathrm{Ba}\left(\mathrm{AlEt}_{4}\right)_{2}\right]_{n}$ and its gallate derivatives $\left[\mathrm{Ba}\left(\mathrm{GaEt}_{4}\right)_{2}\right]_{n}$ and $\left[\mathrm{Ba}\left(\mathrm{GaEt}_{4}\right)_{2} \cdot\right.$ toluene $_{2}$, all obtained from $\left[\mathrm{Ba}\left\{\mathrm{N}\left(\mathrm{SiMe}_{2} \mathrm{H}\right)_{2}\right]_{n} \cdot{ }^{[32]}\right.$ The hybrid material [Ba(AlEt $\left.)_{2}\right] @ M C M-41$ was made by grafting the aluminate onto mesoporous silica MCM-41. ${ }^{[56]}$ The Ba-aluminate had limited alkylating power, since it was simply ligated in the presence of $\beta$-diimines, e.g. to generate $\left[\left\{\mathrm{PhC}=\mathrm{NCH}_{2} \mathrm{CH}_{2} \mathrm{~N}=\mathrm{CPh}\right\} \mathrm{Ba}\left(\mathrm{AlEt}_{4}\right)_{2}\right]_{n}$, without detectable alkylation of the imines; by contrast, treatment of $\left[\mathrm{Mg}\left(\mathrm{AlMe}_{4}\right)_{2}\right]_{n}$ with $\mathrm{PhCH}=\mathrm{NCH}_{2} \mathrm{CH}_{2} \mathrm{~N}=\mathrm{CHPh}$ provoked the formation of the monoalkylated product, $\left[\left\{\mathrm{PhCH}(\mathrm{Me}) \mathrm{NCH}_{2} \mathrm{CH}_{2} \mathrm{~N}=\mathrm{CHPh}\right\} \mathrm{MgMe}\right] .{ }^{[57]}$ Finally, although they do not enter the category of barium alkyls, one may note that a large number of barium cyclopentadienyls and related compounds were reported early on and have been extensively reviewed elsewhere ${ }^{[58]}$ and that a number of acetylides supported by crown-ethers, e.g. $\left[\mathrm{Ba}\left(\mathrm{CCSiPh}_{3}\right)_{2} \cdot\left(18\right.\right.$-crown-6)], have also been described. ${ }^{[59]}$ 

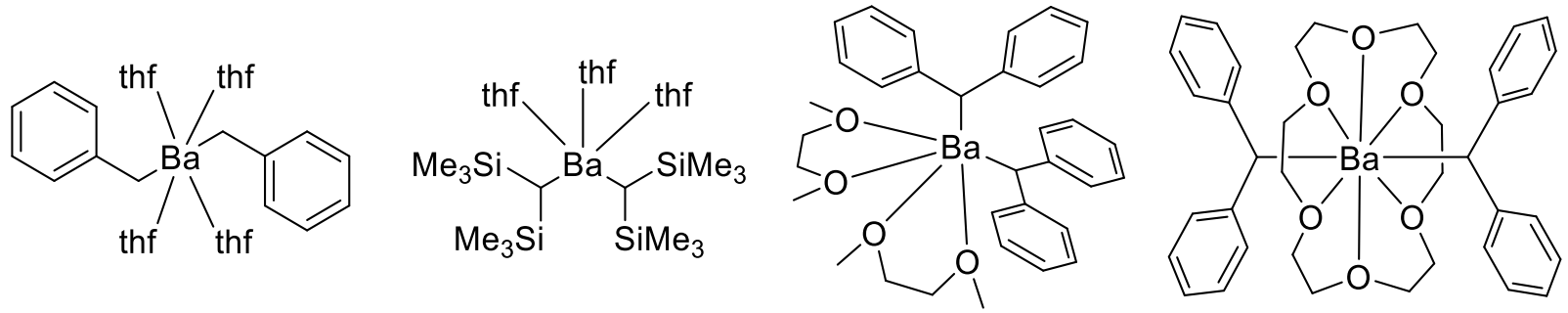

Figure 7. Selected homoleptic barium-alkyl complexes. ${ }^{[50-52]}$

\section{Amido ligands}

Although alkyl ligands make highly active catalysts and synthetic precursors, the most widely used homoleptic complexes are barium amides. Of these amides, the most common are $\left[\mathrm{Ba}\left\{\mathrm{N}\left(\mathrm{SiMe}_{3}\right)_{2}\right\}_{2} \cdot(\text { thf })_{2}\right]$ and its donor free analogue $\left[\mathrm{Ba}\left\{\mu-\mathrm{N}\left(\mathrm{SiMe}_{3}\right)_{2}\right\}\left\{\mathrm{N}\left(\mathrm{SiMe}_{3}\right)_{2}\right\}\right]_{2}$, first reported by Westerhausen and Caulton separately in 1991. ${ }^{[26,60]}$ Both of these compounds have been used as versatile synthetic precursors, and also as precatalysts in a range of catalytic transformations including olefin hydroelementation, ${ }^{[61,43]}$ imine $^{[62]}$ or alkene ${ }^{[63]}$ hydrogenation, and the dehydrocoupling of amines with either hydrosilanes ${ }^{[64]}$ and boranes. ${ }^{[65]}$ The syntheses of both the donor free compound and its thf adduct have been thoroughly surveyed. ${ }^{[1,5,66]}$ However, some recent contributions examined the influence of the nature of various coordinated Lewis bases on the structure and the solution stability of $\left[\mathrm{Ba}\left\{\mathrm{N}\left(\mathrm{SiMe}_{3}\right)_{2}\right\}_{2} \cdot(\text { donor })_{\mathrm{x}}\right]$ adducts. ${ }^{[27-28,67-70]}$ A structural comparison of the various adducts of $\mathrm{Ba}\left\{\mathrm{N}\left(\mathrm{SiMe}_{3}\right)_{2}\right\}_{2}$ is collated in Table 1 and Figure 8; the various ligands coordinate to the metal include di- and triamines, cyclic ethers, aminoethers and carbenes. The disilazide $\left\{\mathrm{N}\left(\mathrm{SiMe}_{2} \mathrm{H}\right)_{2}\right\}^{-}$has also been added to Table 1. Although it provides less steric protection to the metal centre, it also provides stabilising $\beta$-Si-H $\cdots$ Ba anagostic interactions that have been shown to inhibit Schlenk redistribution in complexes where the $\left\{\mathrm{N}\left(\mathrm{SiMe}_{3}\right)_{2}\right\}^{-}$ligand cannot; these considerations are discussed in the section focusing on secondary interactions in barium chemistry. ${ }^{[42]}$

Although direct comparisons between the structural data is not possible for the majority of the Lewis base adducts, some generalised comments on bonding patterns and trends can be drawn. For the amidebridged species, two sets of Ba-N interatomic distances are reported; the first is for the Ba-to- $\mathrm{N}_{\text {terminal }}$ bond and the second is for the bridging Ba-to- $\mathrm{N}_{\text {bridge. }}$ In some compounds the bond distances have been averaged when appropriate. For the whole series, increasing the coordination number $(\mathrm{CN})$ at the barium centre has a net increase in the Ba- $\mathrm{N}_{\text {silazide }}$ bond length to the disilazides, with the shortest $\mathrm{Ba}-\mathrm{N}$ interatomic distance (average) of 2.5716(13) $\AA$ for the three-coordinate mono-Me 4 thf adduct, while the longest bond length of 2.7113(11) $\AA$ is for the 6 coordinate dmmea adduct. Replacing one the OMe groups on the dme adduct with more sterically demanding $\mathrm{NMe}_{2}$ group (both complexes have a $\mathrm{CN}$ of 6) to give the dmmea adduct results in a small lengthening of the Ba- $\mathrm{N}_{\text {silazide }}$ bond distances from 2.696(?) to 2.7113(11) $\AA$. When 
comparing the 4 coordinate complexes $\left[\mathrm{Ba}\left\{\mathrm{N}\left(\mathrm{SiMe}_{3}\right)_{2}\right\}_{2} \cdot(\text { thf })_{2}\right]$ and $\left[\mathrm{Ba}\left\{\mathrm{N}\left(\mathrm{SiMe}_{3}\right)_{2}\right\}_{2} \cdot\right.$ tmeda $]$, this difference between $\mathrm{O}$ and $\mathrm{N}$ donors is even less pronounced, barely increasing from 2.592(6) $\AA$ to 2.5979(13) A. Increasing the donor strength of the Lewis base appears to make a negligible difference to the $\mathrm{Ba}-\mathrm{N}_{\text {silazide }}$ bond lengths, as can be seen from the difference between the five-coordinate thp and pmdeta complexes (2.6257(16) and 2.6340(16) Å respectively), but a direct comparison is likely to be hindered by the changing steric profile of the ligands. As both the bis $(\mathrm{CN}=4)$ and tris $(\mathrm{CN}=5)$ thf adducts are known, the effect of changing the ethereal solvent from thf to the weaker donor tetrahydropyran (thp) can be directly compared. Adding an extra equivalent of thf to the bis-thf adduct increases both the Ba- $\mathrm{N}_{\text {silazide }}$ and Ba-O bond lengths, as would be expected due to the increased steric demand and greater electronic density at metal. Changing from the tris(thf) to tris(thp) adduct, both being $\mathrm{CN}=5$, results in longer $\mathrm{Ba}-\mathrm{O}$ bond length, although a slightly shorter $\mathrm{Ba}-\mathrm{N}_{\text {silazide }}$ distance. This is in contrast to the calcium congeners $\left[\mathrm{Ca}\left\{\mathrm{N}\left(\mathrm{SiMe}_{3}\right)_{2}\right\}_{2} \cdot(\text { thf })_{2}\right]$ and $\left[\mathrm{Ca}\left\{\mathrm{N}\left(\mathrm{SiMe}_{3}\right)_{2}\right\}_{2} \cdot(\mathrm{thp})_{2}\right]$, in which the change from thf to the more sterically demanding, less basic thp, increases the Ca-N bond length by $0.017 \AA{ }^{[71]}$. Hence, within monometallic complexes, coordination number seems to be the only strongly correlated variable to Ba- $\mathrm{N}_{\text {silazide }}$ bond distance. When disilazide $\left\{\mathrm{N}\left(\mathrm{SiMe}_{2} \mathrm{H}\right)_{2}\right\}^{-}$is used instead of $\left\{\mathrm{N}\left(\mathrm{SiMe}_{3}\right)_{2}\right\}^{-}$with access to excess thf, the $\mathrm{CN}$ increases from four in $\left[\mathrm{Ba}\left\{\mathrm{N}\left(\mathrm{SiMe}_{3}\right)_{2}\right\}_{2} \cdot(\text { thf })_{2}\right]$ to six in $\left[\mathrm{Ba}\left\{\mathrm{N}\left(\mathrm{SiMe}_{2} \mathrm{H}\right)_{2}\right\}_{2} \cdot(\text { thf })_{4}\right]$, likely due to the smaller steric profile of tetramethyldisilazide; the $\mathrm{Ba}-\mathrm{N}_{\text {silazide }}$ and $\mathrm{Ba}-\mathrm{O}$ interatomic distances increase accordingly. 
Table 1. Homoleptic [Ba]-N( $\left.\mathrm{SiMe}_{3}\right)_{2}$ and $[\mathrm{Ba}]-\mathrm{N}\left(\mathrm{SiMe}_{2} \mathrm{H}\right)_{2}$ silazides and their adducts.

\begin{tabular}{|c|c|c|c|c|c|}
\hline Compound & $\mathrm{CN}$ & $\mathrm{Ba}-\mathrm{N}(\AA)$ & Ba-donor $(\AA)$ & $\mathrm{N}-\mathrm{Ba}-\mathrm{N}{ }^{\prime}\left({ }^{\circ}\right)$ & Ref \\
\hline$\left[\mathrm{Ba}\left\{\mu-\mathrm{N}\left(\mathrm{SiMe}_{3}\right)_{2}\right\}\left\{\mathrm{N}\left(\mathrm{SiMe}_{3}\right)_{2}\right\}\right]_{2}$ & 3 & $2.576(3)^{\mathrm{a}}, 2.822(4)^{\mathrm{b}}$ & - & $134.8(1)^{c}, 81.9(1)^{d}$ & [26] \\
\hline \multirow[t]{2}{*}[\mathrm{Ba}\{\mathrm{N}(\mathrm{SiMe}_{3})_{2}\}_{2}\cdot\mathrm{Me}_{4}\mathrm{thf}]{$^{\mathrm{e}}$} & 3 & 2.5521(13), & $2.7875(11)$ & $112.05(4)$ & [27] \\
\hline & & $2.5911(13)$ & & & \\
\hline$\left[\mathrm{Ba}\left\{\mathrm{N}\left(\mathrm{SiMe}_{3}\right)_{2}\right\}_{2} \cdot \mathrm{NHC}\right]^{\dagger}$ & 3 & $2.584(3)$ & $2.915(4)$ & $123.88(11)$ & [67] \\
\hline$\left[\mathrm{Ba}\left\{\mu-\mathrm{N}\left(\mathrm{SiMe}_{3}\right)_{2}\right\}\left\{\mathrm{N}\left(\mathrm{SiMe}_{3}\right)_{2}\right\} \cdot \text { thf }\right]_{2}$ & 4 & $2.602(9)^{a}, 2.869(10)^{b}$ & $2.773(8)$ & $129.7(3)^{c}, 85.0(3)^{d}$ & [26] \\
\hline$\left[\mathrm{Ba}\left\{\mathrm{N}\left(\mathrm{SiMe}_{3}\right)_{2}\right\}_{2} \cdot(\text { thf })_{2}\right]$ & 4 & $2.592(6)$ & $2.717(6), 2.745(6)$ & $116.77(21)$ & {$[60]$} \\
\hline$\left[\mathrm{Ba}\left\{\mathrm{N}\left(\mathrm{SiMe}_{3}\right)_{2}\right\}_{2} \cdot \mathrm{tmeda}\right]^{\mathrm{g}}$ & 4 & $2.5979(13)$ & $2.8905(14)$ & $122.40(6)$ & [68] \\
\hline$\left[\mathrm{Ba}\left\{\mathrm{N}\left(\mathrm{SiMe}_{3}\right)_{2}\right\}_{2} \cdot \mathrm{CAAC} \cdot \mathrm{thf}\right]^{\mathrm{h}}$ & 4 & $2.600(3), 2.617(3)$ & $3.108(3)^{i}, 2.798(3)^{j}$ & $108.22(10)$ & [69] \\
\hline$\left[\mathrm{Ba}\left\{\mathrm{N}\left(\mathrm{SiMe}_{3}\right)_{2}\right\}_{2} \cdot \mathrm{pmdeta}\right]^{\mathrm{k}}$ & 5 & $2.6340(16)$ & 2.993(2), 3.079(2) & $109.22(5)$ & [68] \\
\hline$\left[\mathrm{Ba}\left\{\mu-\mathrm{N}\left(\mathrm{SiMe}_{2} \mathrm{H}\right)_{2}\right\}\left\{\mathrm{N}\left(\mathrm{SiMe}_{2} \mathrm{H}\right)_{2}\right\} \cdot \text { phen }\right]_{2}{ }^{\prime}$ & 5 & $2.630(3)^{\mathrm{a}}, 2.891(3)^{\mathrm{b}}$ & $2.892(3), 2.902(3)$ & $126.4(1)^{c}, 77.5(1)^{d}$ & [32b] \\
\hline$\left[\mathrm{Ba}\left\{\mathrm{N}\left(\mathrm{SiMe}_{3}\right)_{2}\right\}_{2} \cdot(\text { thf })_{3}\right]\left[\mathrm{Li}\left(\mu-\mathrm{N}\left(\mathrm{SiMe}_{3}\right)_{2}\right\} \cdot \text { thf }\right]_{2}$ & 5 & $2.634(8)$ & $2.772(6), 2.844(13)$ & $110.9(4)$ & {$[70]$} \\
\hline$\left[\mathrm{Ba}\left\{\mathrm{N}\left(\mathrm{SiMe}_{3}\right)_{2}\right\}_{2} \cdot(\mathrm{thp})_{3}\right]^{\mathrm{m}}$ & 5 & $2.6257(16)$ & $2.829(2), 2.8688(15)$ & 108.62(7) & [68] \\
\hline$\left[\mathrm{Ba}\left\{\mathrm{N}\left(\mathrm{SiMe}_{3}\right)_{2}\right\}_{2} \cdot(\mathrm{dme})_{2}\right]^{\mathrm{n}}$ & 6 & $2.686(?)^{\circ}$ & $2.766(?)-2.861(?)^{\circ}$ & $125.3(?)^{\circ}$ & [68] \\
\hline$\left[\mathrm{Ba}\left\{\mathrm{N}\left(\mathrm{SiMe}_{3}\right)_{2}\right\}_{2} \cdot \mathrm{dmmea}\right]^{\mathrm{p}}$ & 6 & $2.7113(11)$ & $2.7844(9)^{q}, 3.060(1)^{r}$ & $128.97(5)$ & [28] \\
\hline$\left[\mathrm{Ba}\left\{\mathrm{N}\left(\mathrm{SiMe}_{2} \mathrm{H}\right)_{2}\right\}_{2} \cdot(\text { thf })_{4}\right]$ & 6 & $2.669(2)$ & $2.772(2), 2.801(2)$ & 129.92(9) & [32a] \\
\hline
\end{tabular}

[a] terminal. [b] bridging. [c] terminal $\mathrm{N}$ to bridging $\mathrm{N}$. [d] bridging $\mathrm{N}$ to bridging $\mathrm{N}$. [e] $\mathrm{Me}_{4}$ thf $=2,2,5,5$-tetramethyltetrahydrofuran. [ $\mathrm{f}$ ] $\mathrm{NHC}=1,3$-bis(mesityl)imidazol-2-ylidene. $[\mathrm{g}]$ tmeda $=$ tetramethylethylenediamine. $[\mathrm{h}]$ CAAC $=1$-(2,6-diisopropylphenyl)-3,3,5,5tetramethylpyrrolidine-2-ylidene. Note that this compound was obtained upon recrystallisation from the thf-free parent in thf. [i] $\mathrm{C}$ bound. [j] O-bound. [k] pmdeta = N,N,N,N",N"-pentamethyldiethylene-triamine. [l] phen = 1,10-phenanthroline. [m] thp = tetrahydropyran. [n] dme = dimethoxyethane. [o] Esd's and CIF file not available. [p] dmmea = dimethylmethoxyethylamine. [q] Obound. [r] N-bound. 
Coordination number

$$
\mathrm{CN}=3 \quad \begin{gathered}
\left(\mathrm{SiMe}_{3}\right)_{2} \\
\left(\mathrm{Me}_{3} \mathrm{Si}\right)_{2} \mathrm{~N}-\mathrm{Ba}^{-i} \mathrm{~N}_{\mathrm{N}} \mathrm{Ba}-\mathrm{N}\left(\mathrm{SiMe}_{3}\right)_{2} \\
\left(\mathrm{SiMe}_{3}\right)_{2} \\
{\left[\mathrm{Ba}\left\{\mu-\mathrm{N}\left(\mathrm{SiMe}_{3}\right)_{2}\right\}\left\{\mathrm{N}\left(\mathrm{SiMe}_{3}\right)_{2}\right\}\right]_{2}}
\end{gathered}
$$

[26]

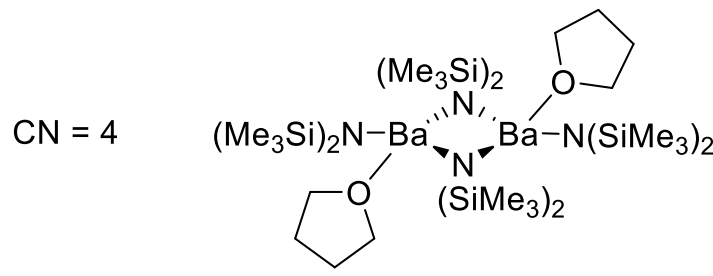

$\left[\mathrm{Ba}\left\{\mu-\mathrm{N}\left(\mathrm{SiMe}_{3}\right)_{2}\right\}\left\{\mathrm{N}\left(\mathrm{SiMe}_{3}\right)_{2}\right\} \cdot \text { thf }\right]_{2}$

[26]

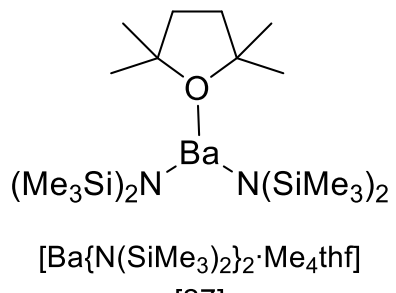

[27]

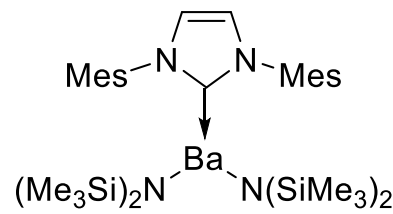

$\left[\mathrm{Ba}\left\{\mathrm{N}\left(\mathrm{SiMe}_{3}\right)_{2}\right\}_{2} \cdot \mathrm{NHC}\right]$

[67]

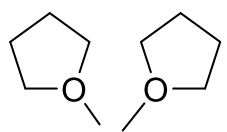

$\left(\mathrm{Me}_{3} \mathrm{Si}_{2}\right)_{2} \mathrm{~N}^{-\mathrm{Ba}} \mathrm{N}\left(\mathrm{SiMe}_{3}\right)_{2} \quad\left(\mathrm{Me}_{3} \mathrm{Si}_{2}\right)_{2} \mathrm{~N}^{-\mathrm{Ba}}{ }^{-} \mathrm{N}\left(\mathrm{SiMe}_{3}\right)_{2}$

$\left[\mathrm{Ba}\left\{\mathrm{N}\left(\mathrm{SiMe}_{3}\right)_{2}\right\}_{2} \cdot(\text { thf })_{2}\right]$

[60]

$\left[\mathrm{Ba}\left\{\mathrm{N}\left(\mathrm{SiMe}_{3}\right)_{2}\right\}_{2} \cdot \mathrm{tmeda}\right]$

[68]

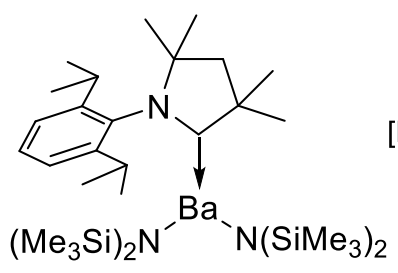

$\left[\mathrm{Ba}\left\{\mathrm{N}\left(\mathrm{SiMe}_{3}\right)_{2}\right\}_{2} \cdot \mathrm{CAAC} \cdot\right.$ thf $]$

[69]

$\mathrm{CN}=5$
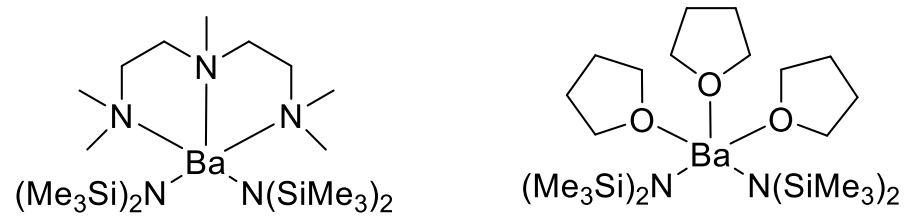

$\left[\mathrm{Ba}\left\{\mathrm{N}\left(\mathrm{SiMe}_{3}\right)_{2}\right\}_{2} \cdot\right.$ pmdeta]

[68]

$\left[\mathrm{Ba}\left\{\mathrm{N}\left(\mathrm{SiMe}_{3}\right)_{2}\right\}_{2} \cdot(\text { thf })_{3}\right]$

[70]

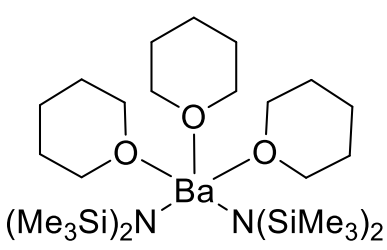

$\left[\mathrm{Ba}\left\{\mathrm{N}\left(\mathrm{SiMe}_{3}\right)_{2}\right\}_{2} \cdot(\text { thp })_{3}\right]$

[68]

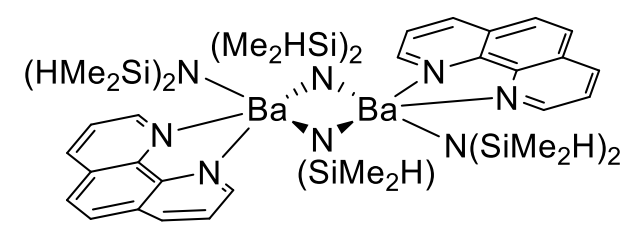

$\left[\mathrm{Ba}\left\{\mu-\mathrm{N}\left(\mathrm{SiMe}_{2} \mathrm{H}\right)_{2}\right\}\left\{\mathrm{N}\left(\mathrm{SiMe}_{2} \mathrm{H}\right)_{2}\right\} \cdot \mathrm{phen}\right]_{2}$ [32b]

$\mathrm{CN}=6$

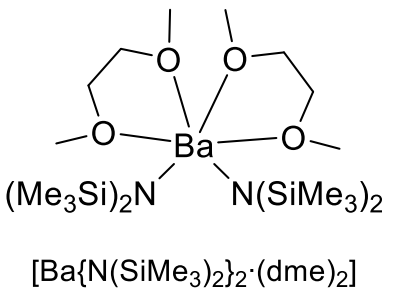

[68]

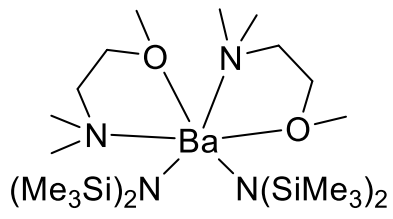

$\left[\mathrm{Ba}\left\{\mathrm{N}\left(\mathrm{SiMe}_{3}\right)_{2}\right\}_{2} \cdot \mathrm{dmmea}\right]$

[28]<smiles>C1CCC(OCOC2CCCC2)C1</smiles>

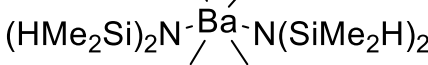

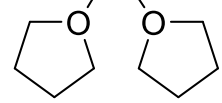

$\left[\mathrm{Ba}\left\{\mathrm{N}\left(\mathrm{SiMe}_{2} \mathrm{H}\right)_{2}\right\}_{2}{ }^{\prime}(\text { thf })_{4}\right]$

[32a]

Figure 8. Homoleptic [Ba]-silazides and their adducts (see Table 1). 


\section{Alkoxide ligands}

The strong tendency for O-based ligands to bridge multiple metal nuclei can result in poorly defined oligomeric species with poor solubility. Phenolates were some of the earliest reported ligands capable of suppressing aggregation to oligomers, thus enabling the isolation of monomeric or dimeric barium complexes. ${ }^{[72]}$ However, their low basicity paired with the relative strength of the Ba-O compared to the weaker Ba-N and especially Ba-C bonds often make these complexes exceedingly stable or unreactive. They are therefore less likely to undergo protonolysis or insertion reactions, both of which are key steps in catalytic cycles and in the derivatisation of barium complexes. Many homoleptic homometallic barium phenolates are known, e.g. $\left[\mathrm{Ba}\left(\mathrm{O}-2,6{ }^{-}{ }^{i} \mathrm{Pr}-\mathrm{C}_{6} \mathrm{H}_{3}\right)_{2} \cdot(\mathrm{dme})_{3}\right],{ }^{[73]}\left[\mathrm{Ba}\left(\mathrm{O}-2,6-{ }^{t} \mathrm{Bu}_{2}-\mathrm{C}_{6} \mathrm{H}_{3}\right){ }_{2} \cdot(\text { pyridine })_{3}\right],{ }^{[74]}[\mathrm{Ba}(\mathrm{O}-$ $\left.\left.2,6-{ }^{i} \mathrm{Pr}_{2}-\mathrm{C}_{6} \mathrm{H}_{3}\right)_{2} \cdot(\text { pyridine })_{4}\right]^{[74]}$ and $\left[\mathrm{Ba}\left\{\mathrm{O}-2-\left(\mathrm{CH}_{2} \mathrm{~N}\left(\mathrm{C}_{2} \mathrm{H}_{5} \mathrm{OMe}\right)_{2}-4,6-{ }^{t} \mathrm{Bu}-\mathrm{C}_{6} \mathrm{H}_{2}\right\}_{2}\right] \cdot{ }^{[75]}\right.$

Homometallic barium alkoxides are much rarer, as formation of polynuclear species with high coordination numbers at $\mathrm{Ba}$ often prevents the isolation of discrete molecular complexes, as observed in $\left[\mathrm{Ba}_{5}(\mathrm{Omesityl})_{5}(\mathrm{OMe})_{5} \cdot(\mathrm{dme})_{4}\right] .{ }^{[76]}$ Although a number of heterobimetallic barium alkoxides are also known, ${ }^{[77]}$ only few homoleptic monometallic molecular barium alkoxide species are currently described. They involve the perfluorinated $\left(\mathrm{CF}_{3}\right)_{3} \mathrm{CO}^{-}$alkoxide to stabilise the eight-coordinate solvate $\left[\mathrm{Ba}\left\{\mathrm{OC}\left(\mathrm{CF}_{3}\right)_{3}\right]_{2} \cdot(\mathrm{dme})_{3}\right]$, a volatile precursor for metal organic vapour deposition. ${ }^{[78]}$ Fluoroalkoxides with polyether donor groups have also been used for the same aim. ${ }^{[79], ~ I n ~ t h e s e ~ c o m p l e x e s, ~ t h e ~ b u l k y ~ e l e c t r o n-~}$ withdrawing $\mathrm{CF}_{3}$ groups in $\alpha$ position(s) to the alkoxide prevent aggregation.

Similar to the problems with alkoxides, a small number of related Ba-siloxides have been reported (Figure 9), often as clusters, such as $\left[\mathrm{Ba}_{3}\left(\mu_{3}-\mathrm{OSiPh}_{3}\right)_{2}\left(\mu_{2}-\mathrm{OSiPh}_{3}\right)\left(\mathrm{OSiPh}_{3}\right) \cdot\right.$ thf $]$, an O-bridged complex with one barium centre with $\mathrm{CN}=4$ and others with $\mathrm{CN}=5{ }^{[80]}\left[\mathrm{Ba}_{3}\left(\mathrm{OSiPh}_{2} \mathrm{OSiPh}_{2} \mathrm{O}\right)_{3} \cdot(\text { tetraglyme })_{2}\right]$ has a somewhat similar structure, with two terminal eight-coordinate Ba-atoms each coordinated by three bridging siloxides and a tetraglyme molecule, and one central seven-coordinate Ba-atom bound to six bridging siloxides and one siloxane. ${ }^{[81]}$ The complex $\left[\mathrm{Ba}\left(\mathrm{OSiPh}_{3}\right)_{2} \cdot(15\right.$-crown-5) thf $]$ exists as a monomer in the solid state due to the many $\pi$ donors of the crown-ether. ${ }^{[82]}$ The non-symmetrical dimeric compound $\left[\mathrm{Ba}_{2}\left\{\mu-\mathrm{OSi}^{t} \mathrm{Bu}_{3}\right\}_{3}\left\{\mathrm{OSi}^{t} \mathrm{Bu}_{3}\right\} \cdot\right.$ thf $]$ contains two four-coordinate barium atoms, ${ }^{[83]}$ one solvated with three bridging siloxides to the other unsolvated barium atom which also has a terminal siloxide. Recently reported was the first solvent-free unsupported siloxide complex, $\left[\left[\mathrm{Ba}_{2}\left\{\mu-\mathrm{OSi}\left(\mathrm{SiMe}_{3}\right)_{3}\right\}_{3}\left\{\mathrm{OSi}\left(\mathrm{SiMe}_{3}\right)_{3}\right\}\right]\right.$ and the solvated $\left[\left[\mathrm{Ba}_{2}\left\{\mu-\mathrm{OSi}\left(\mathrm{SiMe}_{3}\right)_{3}\right\}_{3}\left\{\mathrm{OSi}(\mathrm{SiMe})_{3}\right\} \cdot\right.\right.$ thf $]$, generated from $\left[\mathrm{Ba}\left\{\mu-\mathrm{N}\left(\mathrm{SiMe}_{3}\right)_{2}\right\}\left\{\mathrm{N}\left(\mathrm{SiMe}_{3}\right)_{2}\right\}\right]_{2}$ or $\left[\mathrm{Ba}\left\{\mathrm{N}\left(\mathrm{SiMe}_{3}\right)_{2}\right\}_{2} \cdot(\text { thf })_{2}\right]$ and the bulky silanol $\left(\mathrm{Me}_{3} \mathrm{Si}\right)_{3} \mathrm{SiOH}$ in petroleum ether. ${ }^{[84]}$ The two compounds display the same bonding motif, with the only structural difference being a capping thf in the solvated complex. The unsolvated complex has two different Ba-atoms; a four-coordinate barium centre with one terminal siloxide and three bridging siloxides, and a three-coordinate atom only bound to bridging siloxides. The thf adduct displays the same solid state structural conformation as $\left[\mathrm{Ba}_{2}\left\{\mu-\mathrm{OSi}^{t} \mathrm{Bu}_{3}\right\}_{3}\left\{\mathrm{OSi}^{t} \mathrm{Bu}_{3}\right\} \cdot \mathrm{thf}\right]$. 
This last synthetic protocol contrasts with those used to obtain other Ba-siloxides, which were all prepared in a one-pot method by activation of metallic Ba with ammonia in the presence of two equivalents of the silanol. $\left[\mathrm{Ba}_{2}\left\{\mu-\mathrm{OSi}\left(\mathrm{SiMe}_{3}\right)_{3}\right\}_{3}\left\{\mathrm{OSi}\left(\mathrm{SiMe}_{3}\right)_{3}\right\}\right]$ performs well as a molecular catalyst in the dehydrocoupling of hydrosilanes and silanols for the production of asymmetric siloxanes. ${ }^{[84]}$

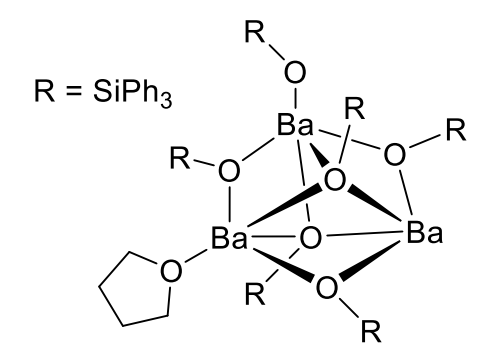

$\left[\mathrm{Ba}_{3}\left(\mu_{3}-\mathrm{OSiPh}_{3}\right)_{2}\left(\mu_{2}-\mathrm{OSiPh}_{3}\right)\left(\mathrm{OSiPh}_{3}\right) \cdot\right.$ thf $]$

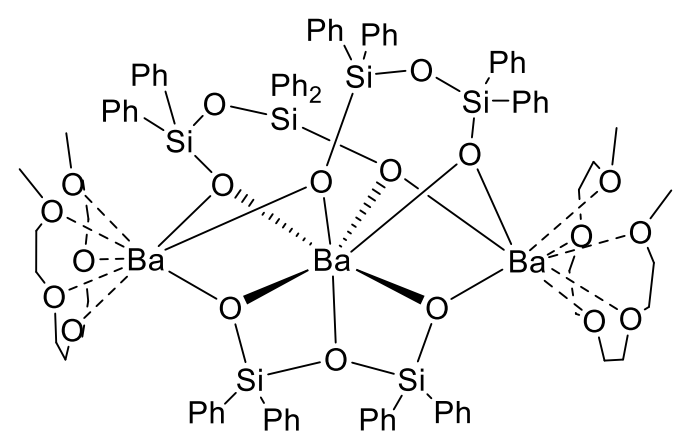

$\left[\mathrm{Ba}_{3}\left(\mathrm{OSiPh}_{2} \mathrm{OSiPh} \mathrm{O}_{2}\right)_{3} \cdot(\text { tetraglyme })_{2}\right]$

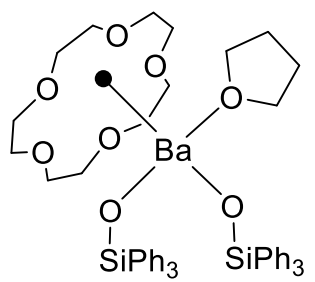

$\left[\mathrm{Ba}\left(\mathrm{OSiPh}_{3}\right)_{2} \cdot(15-\mathrm{crown}-5) \cdot \mathrm{thf}\right]$

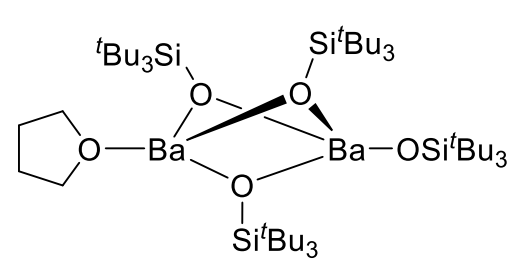

$\left[\mathrm{Ba}_{2}\left\{\mu-\mathrm{OSi}\left(\mathrm{SiMe}_{3}\right)_{3}\right\}_{3}\left\{\mathrm{OSi}\left(\mathrm{SiMe}_{3}\right)_{3}\right\}\right.$ thf $]$

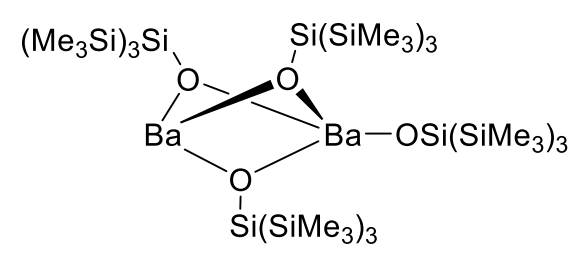

$\left[\mathrm{Ba}_{2}\left\{\mu-\mathrm{OSi}\left(\mathrm{SiMe}_{3}\right)_{3}\right\}_{3}\left\{\mathrm{OSi}\left(\mathrm{SiMe}_{3}\right)_{3}\right\}\right]$

Figure 9. Bonding motifs in barium siloxides. ${ }^{\left[{ }^{[0-84]}\right.}$ Black dot indicates all heteroatoms are metal-bound.

A similar structural motif based on the sterically demanding boryloxide $\left(\left(\mathrm{Me}_{3} \mathrm{Si}\right)_{2} \mathrm{CH}\right)_{2} \mathrm{BO}^{-}$has recently been used to prepare homoleptic barium complexes with coordination numbers of 2-4, the lowest for barium. ${ }^{[25]}$ Boryloxides are described as electron poor analogues of alkoxides, due to the delocalisation of the lone pairs of electron present on the oxygen atom into the vacant $p_{z}$ orbital at boron. The fourcoordinate thf adduct $\left[\mathrm{Ba}\left\{\mathrm{OB}\left(\mathrm{CH}\left(\mathrm{SiMe}_{3}\right)_{2}\right)_{2}\right\}_{2} \cdot(\text { thf })_{2}\right]$ was reported in a high yield from the protonolysis reaction between $\left[\mathrm{Ba}\left\{\mathrm{N}\left(\mathrm{SiMe}_{3}\right)_{2}\right\}_{2} \cdot(\text { thf })_{2}\right]$ and two equivalents of $\left(\left(\mathrm{Me}_{3} \mathrm{Si}\right)_{2} \mathrm{CH}\right)_{2} \mathrm{BOH}$. The heteroleptic boryloxide/amide dimer $\left[\mathrm{Ba}\left\{\mu-\mathrm{N}\left(\mathrm{SiMe}_{3}\right)_{2}\right\}\left\{\mathrm{OB}\left(\mathrm{CH}\left(\mathrm{SiMe}_{3}\right)_{2}\right)_{2}\right\}\right]_{2}$ (Figure 10) could be synthesised via either the protonolysis between $\left(\left(\mathrm{Me}_{3} \mathrm{Si}\right)_{2} \mathrm{CH}\right)_{2} \mathrm{BOH}$ and $\left[\mathrm{Ba}\left\{\mu-\mathrm{N}\left(\mathrm{SiMe}_{3}\right)_{2}\right\}\left\{\mathrm{N}\left(\mathrm{SiMe}_{3}\right)_{2}\right\}\right]_{2}$ or by ligand exchange between equimolar amounts of $\left[\mathrm{Ba}\left\{\mathrm{OB}\left(\mathrm{CH}\left(\mathrm{SiMe}_{3}\right)_{2}\right)_{2}\right\}_{2} \cdot(\text { thf })_{2}\right]$ and $\left[\mathrm{Ba}\left\{\mathrm{N}\left(\mathrm{SiMe}_{3}\right)_{2}\right\}_{2} \cdot(\text { thf })_{2}\right]$, with both methods giving the thf-free complex when carried out in toluene. Very uncharacteristically, the disilazide occupies the bridging position in the heteroleptic dimer, whereas the boryloxide is pushed away in terminal position; this was rationalised to be a result of both steric hindrance and relatively low electronic 
density on the $\mathrm{O}$-atoms due to the delocalisation of their lone pairs. Treatment of the heteroleptic dimer with the borinic acid in petroleum ether gave the homoleptic $\left[\mathrm{Ba}\left\{\mathrm{OB}\left(\mathrm{CH}\left(\mathrm{SiMe}_{3}\right)_{2}\right)_{2}\right\}_{2}\right]$, a unique twocoordinate complex. The reported Ba-O bond lengths of 2.3823(16) and 2.4098(16) $\AA$ match that of the terminal Ba-O bond in the heteroleptic amide dimer $(2.3999(14) \AA)$. Beyond being the first two-coordinate barium complex, this compound is characterised by a very narrow $\mathrm{O}-\mathrm{Ba}-\mathrm{O}$ angle of $130.59(6)^{\circ}$, and by the

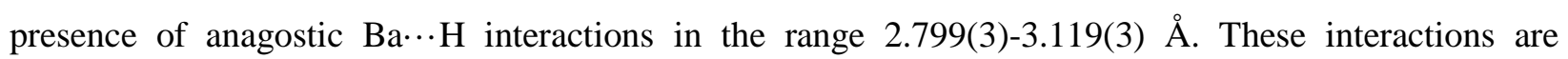
suppressed in the toluene adduct $\left[\mathrm{Ba}\left\{\mathrm{OB}\left(\mathrm{CH}\left(\mathrm{SiMe}_{3}\right)_{2}\right)_{2}\right\}_{2} \cdot\right.$ toluene], which instead displays $\eta^{6}$-coordination of toluene, with Ba-C interatomic distances between 3.341(2) and 3.515(2) $\AA^{\left[{ }^{[85]}\right.}$ These boryloxides catalyse silane/borinic acid (BOH) dehydrocouplings, as outlined in the section dedicated to barium-mediated catalysis.
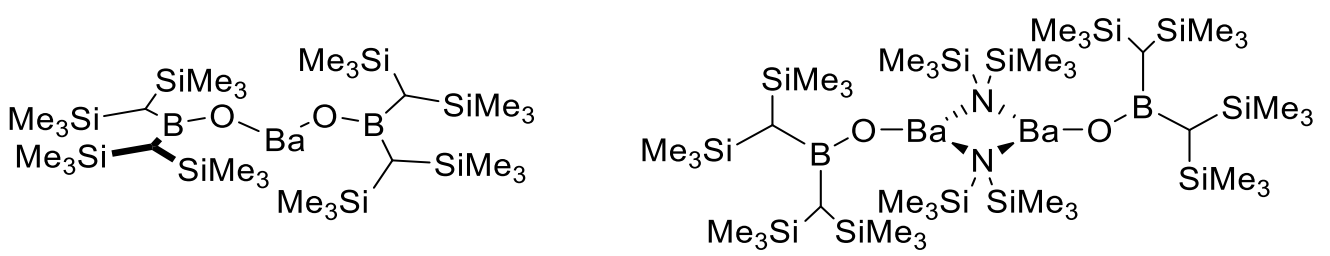

Figure 10. Two- and three-coordinate Ba-boryloxides. ${ }^{[25]}$

\section{Heteroleptic Complexes}

There are very few areas in main group metal chemistry where the importance of kinetically stabilising ligands has been more obvious than for the preparation of stable heteroleptic barium complexes. Until recently, barium had remained reluctant to the many successes achieved elsewhere in alkaline-earth chemistry, mostly due to the issues associated with ligand redistribution. Whereas the fundamental organometallic chemistry of calcium (and strontium) blossomed through the successive syntheses of hitherto elusive species such as soluble hydrides, ${ }^{[18-19]}$ hydroxides ${ }^{[86]}$ or fluorides ${ }^{[87]}$ to name a few, no such feast was achieved with barium for the lack of appropriate ancillary ligand. Besides, the case for suitable ligands in molecular catalysis was also compelling. Although homoleptic Ba complexes can constitute active precatalysts, there are two particular situations in which a bulky spectator ligand is required. First, when the homoleptic complex $\left[\mathrm{Ae}(\mathrm{X})_{2}\right]$ is catalytically active, but insoluble. In this case an ancillary ligand may help both increase solubility of the catalyst $[\{\operatorname{Ligand}\} \operatorname{Ae}(X)]$ and stabilise the heteroleptic species towards ligand redistribution to the potentially catalytically active but insoluble $\left[\mathrm{Ae}(\mathrm{X})_{2}\right]$. An example of this is found in the intermolecular hydrophosphination of styrene by diphenylphosphine using the calciumamide $\left[\left\{\mathrm{BDI}^{\mathrm{DiPP}}\right\} \mathrm{CaN}\left(\mathrm{SiMe}_{3}\right)_{2} \cdot \mathrm{thf}\right]$, which has been shown to have better catalytic activity than the homoleptic precatalyst $\left[\mathrm{Ca}\left\{\mathrm{N}\left(\mathrm{SiMe}_{3}\right)\right\}_{2} \cdot(\text { thf })_{2}\right]$, due to the suppression of redistribution to insoluble $\left[\mathrm{Ca}\left(\mathrm{PPh}_{2}\right)_{2}\right]_{n}{ }^{[88]}$ The second situation is when the utilisation of an ancillary ligand results in a desirable 
improvement to the stability of the complex, or the selectivity of a catalyst. The following sections contain a review of notable ligands reported in the last 10-15 years capable of kinetically stabilising heteroleptic barium complexes.

\section{Nitrogen ligands - chelating amides and derivatives}

Of the ligands used to kinetically stabilise heteroleptic barium complexes, the most common category is chelating amide ligands. The aforementioned $\beta$-diketiminate ligand $\left\{\mathrm{BDI}^{\mathrm{DiPP}}\right\}^{-}$was first used to support heteroleptic Ba-amide compounds in 2005, ${ }^{[21]}$ although homoleptic complexes had been reported earlier. ${ }^{[17,89]}$ As highlighted in Figure 11, the compounds $\left[\left\{\mathrm{BDI}^{\mathrm{DiPP}}\right\} \mathrm{AeN}\left(\mathrm{SiMe}_{3}\right)_{2} \cdot\right.$ thf $](\mathrm{Ae}=\mathrm{Ca}, \mathrm{Sr}, \mathrm{Ba})$ were synthesised via a one-pot salt-metathesis/protonolysis sequence from the alkaline-earth diiodide, free proligand and two equivalents of the potassium amide $\left[\mathrm{KN}\left(\mathrm{SiMe}_{3}\right)_{2}\right] \cdot{ }^{[21,90]}$ Although the Ca compound was isolated as a pure solid, both the $\mathrm{Sr}$ and Ba congeners were only isolated with a significant amount (ca. 5$30 \%)$ of the homoleptic complexes $\left[\left\{\mathrm{BDI}^{\mathrm{DiPP}}\right\}_{2} \mathrm{Ae}\right]$. The authors also reported the failure of the direct protonolysis reaction between $\left\{\mathrm{BDI}^{\mathrm{DiPP}}\right\} \mathrm{H}$ and the homoleptic amide $\left[\mathrm{Ba}\left\{\mathrm{N}\left(\mathrm{SiMe}_{3}\right)_{2}\right\}_{2} \cdot(\text { thf })_{2}\right]$ due to contamination with redistribution products, and also noted that the desired complex could not be purified by fractional crystallisation. However, it was shown that with the less bulky amide $\left[\mathrm{KN}\left(\mathrm{SiMe}_{2} \mathrm{H}\right)_{2}\right]_{n}$ instead of $\left[\mathrm{KN}\left(\mathrm{SiMe}_{3}\right)_{2}\right]$, the resulting heteroleptic complexes $\left[\left\{\mathrm{BDI}^{\mathrm{DiPP}}\right\} \mathrm{AeN}\left(\mathrm{SiMe}_{2} \mathrm{H}\right)_{2} \cdot(\mathrm{thf})_{2}\right]$ were stable towards ligand scrambling for both strontium and barium, due to the stabilising Ae $\cdots \mathrm{H}-\mathrm{Si}$ secondary anagostic interactions and the additional coordinated thf molecule. ${ }^{[43,91]}$

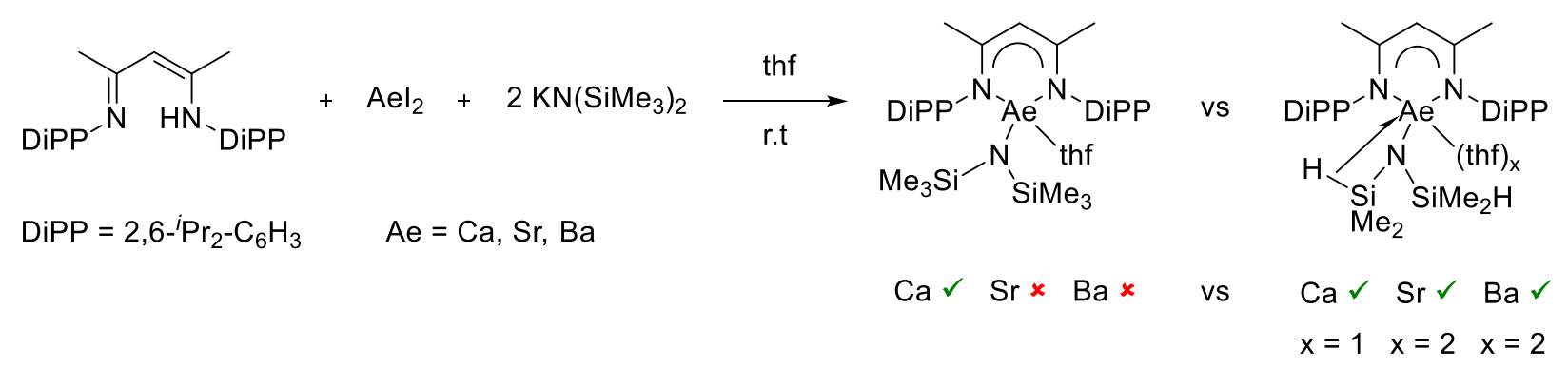

Figure 11. Synthesis of heteroleptic Ae-amides supported by the $\beta$-diketiminate $\left\{\mathrm{BDI}^{\mathrm{DiPP}}\right\}^{-}$. $^{[21,43,91]}$

The triazenide $\left\{\left(\mathrm{Ter}^{\mathrm{Mes}}\right) \mathrm{NNN}\left(2-\mathrm{Trip}-\mathrm{C}_{6} \mathrm{H}_{4}\right\}^{-}\right.$using a terphenyl group has been used to stabilise the complex $\left[\left\{\left(2,6-\mathrm{Mes}_{2}-\mathrm{C}_{6} \mathrm{H}_{3}\right) \mathrm{NNN}\left(2-\mathrm{Trip}_{-} \mathrm{C}_{6} \mathrm{H}_{4}\right\} \mathrm{Ba}\left(\mathrm{C}_{6} \mathrm{~F}_{5}\right)\right] \cdot{ }^{[34]}\right.$ The barium pentafluorophenyl intermediate $\left[\mathrm{Ba}\left(\mathrm{C}_{6} \mathrm{~F}_{5}\right)_{2} \cdot(\text { thf })_{\mathrm{x}}\right]$ was synthesised by transmetallation/deprotonation procedure between $\left[\mathrm{Hg}\left(\mathrm{C}_{6} \mathrm{~F}_{5}\right)_{2}\right]$ and barium metal in thf (Figure 12). The solid-state structure shows metal- $\pi$ arene interactions with both one of the flanking aromatic rings of the terphenyl and the biphenyl moiety. Interestingly, although the $\mathrm{Ca}$ and $\mathrm{Sr}$ congeners were also synthesised, only the Ca analogue was isolated with a coordinated thf molecule. The 
calcium analogue only showed one metal- $\pi$ arene interaction, likely due to the smaller ionic radii of Ca. The authors proposed that the thf coordination competed with the arene interaction to allow the isolation of the solvent-free strontium and barium derivatives.

Triazenide ligand
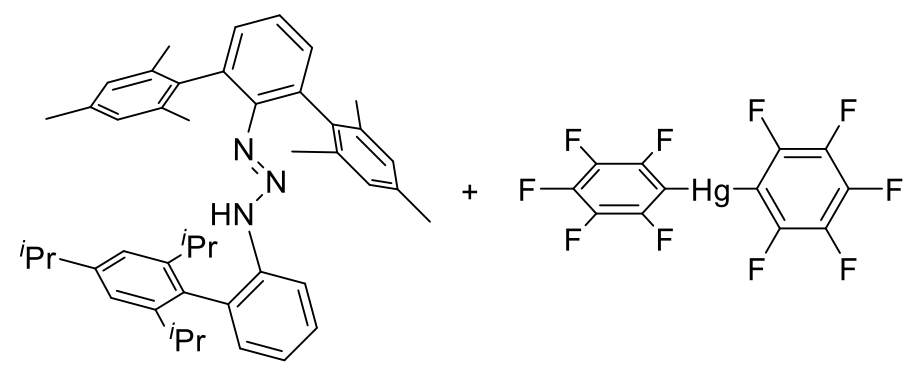
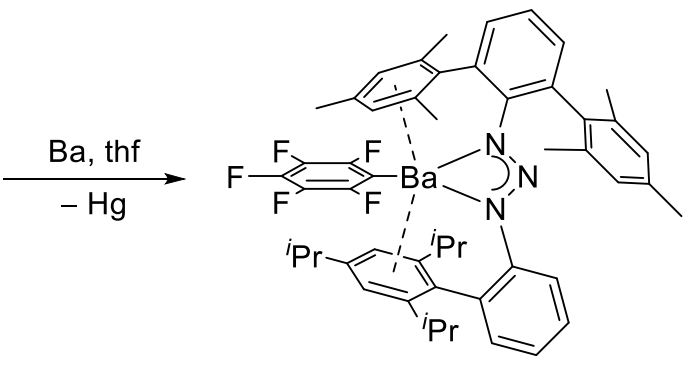

$\left[\left\{\left(2,6-\mathrm{Mes}_{2}-\mathrm{C}_{6} \mathrm{H}_{3}\right) \mathrm{NNN}\left(2-\right.\right.\right.$ Trip- $\left.\left._{6} \mathrm{H}_{4}\right\} \mathrm{Ba}\left(\mathrm{C}_{6} \mathrm{~F}_{5}\right)\right]$

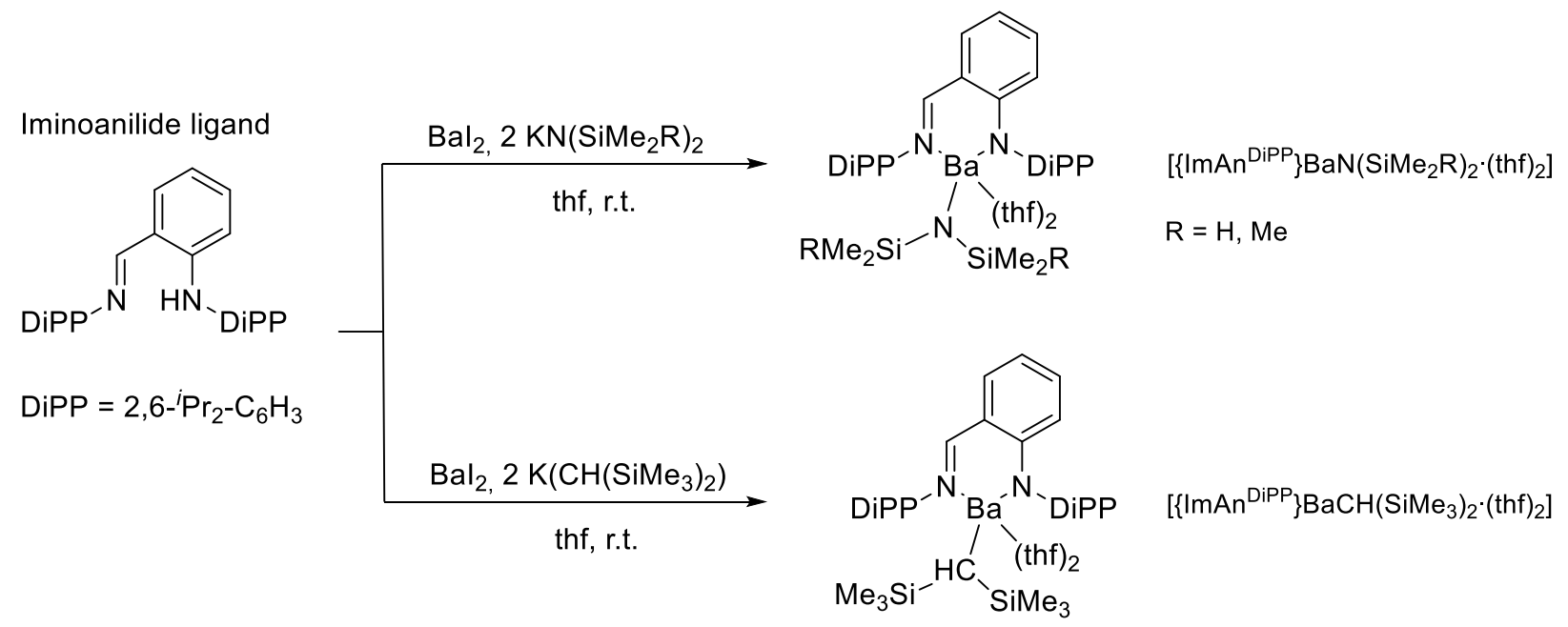

Figure 12. One-pot syntheses of heteroleptic Ba-triazenide ${ }^{[34]}$ and Ba-iminoanilide ${ }^{[43,54,92]}$ complexes.

The iminoanilide ligand $\left\{\operatorname{ImAn}{ }^{\mathrm{DiPP}}\right\}^{-}$has been used to obtain both heteroleptic amide and alkyl barium complexes as their thf solvates (Figure 12). ${ }^{[43,54,92]}$ Adapting the synthetic protocol described in earlier works, ${ }^{[1,90]}$ the reaction between $\left\{\operatorname{ImAn}^{\mathrm{DiPP}}\right\} \mathrm{H}, \mathrm{BaI}_{2}$ and 2 equivalents of either $\left[\mathrm{KN}\left(\mathrm{SiMe}{ }_{2} \mathrm{R}\right)_{2}\right]_{n}$ or $\left[\mathrm{K}\left(\mathrm{CH}\left(\mathrm{SiMe}_{3}\right)_{2}\right)\right]_{n}$ gave the desired compounds in moderate yields of $45 \%(\mathrm{R}=\mathrm{Me}), 56 \%(\mathrm{R}=\mathrm{H})$ for the amides $\left[\left\{\operatorname{ImAn}^{\mathrm{DiPP}}\right\} \mathrm{BaN}\left(\mathrm{SiMe}_{2} \mathrm{R}\right)_{2} \cdot(\text { thf })_{2}\right]$, and $52 \%$ for the alkyl $\left[\left\{\operatorname{ImAn}^{\mathrm{DiPP}}\right\} \mathrm{BaCH}\left(\mathrm{SiMe}_{3}\right)_{2} \cdot(\text { thf })_{2}\right]$. All compounds were isolated as monomeric five-coordinate, disolvated complexes. Both iminoanilidesupported barium amides resisted Schlenk redistribution up to $60{ }^{\circ} \mathrm{C}$ in deuterated benzene. The congeneric calcium and strontium complexes were also reported with different numbers of coordinated thf molecules. 
A more cumbersome version of the $\beta$-diketiminate $\left\{\mathrm{BDI}^{\mathrm{DiPP}}\right\}^{-}$has also been reported, where the ${ }^{i} \mathrm{Pr}$ group on the 2,6 positions of the flanking phenyl rings have been replaced by bulkier isopentyl groups. ${ }^{\text {[29] }}$ The 'superbulky' proligand $\left\{\mathrm{BDI}^{\mathrm{DiPeP}}\right\} \mathrm{H}$ was hence used to generate stable complexes of the three large alkaline earths $(\mathrm{Ca}, \mathrm{Sr}, \mathrm{Ba})$, although only the barium congener is discussed here. The three-coordinate complex $\left[\left\{\mathrm{BDI}^{\mathrm{DiPeP}}\right\} \mathrm{BaN}\left(\mathrm{SiMe}_{3}\right)_{2}\right]$ was synthesised via the protonolysis of $\left\{\mathrm{BDI}{ }^{\mathrm{DiPeP}}\right\} \mathrm{H}$ and $[\mathrm{Ba}\{\mu-$ $\left.\left.\mathrm{N}\left(\mathrm{SiMe}_{3}\right)_{2}\right\}\left\{\mathrm{N}\left(\mathrm{SiMe}_{3}\right)_{2}\right\}\right]_{2}$, which required heating to $140{ }^{\circ} \mathrm{C}$ and reaction times of 5 days (Figure 13). Replacing the isopropyl groups by isopentyl ones drastically enhanced the stability of the heteroleptic complex towards ligand redistribution. The unsolvated $\left[\left\{\mathrm{BDI}^{\mathrm{DiPeP}}\right\} \mathrm{BaN}\left(\mathrm{SiMe}_{3}\right)_{2}\right]$ is stable at $120{ }^{\circ} \mathrm{C}$ for up to 14 days in toluene, whereas the thf-free $\left[\left\{\mathrm{BDI}^{\mathrm{DiPP}}\right\} \mathrm{BaN}\left(\mathrm{SiMe}_{3}\right)_{2}\right]$ redistributes to $33 \%$ homoleptic $\left[\mathrm{Ba}\left\{\mathrm{BDI}^{\mathrm{DiPP}}\right\}_{2}\right]$ after 3 days at $20^{\circ} \mathrm{C}$. The four-coordinate thf-solvate $\left[\left\{\mathrm{BDI}^{\mathrm{DiPeP}}\right\} \mathrm{BaN}\left(\mathrm{SiMe}_{3}\right)_{2} \cdot\right.$ thf $]$ was also prepared, although the reaction time necessary for its synthesis increased to 9 days. This was interpreted as an indication that pre-coordination of the $\beta$-diketiminate onto $\left[\mathrm{Ba}\left\{\mathrm{N}\left(\mathrm{SiMe}_{3}\right)_{2}\right\}_{2}\right]_{2}$ is a mandatory first step.

Somewhat related to $\beta$-diketiminates, the dipyrromethenide $\left\{D P M^{\text {Anth }}\right\}^{-}$having flanking anthracenyls that provide steric bulk has yielded $\left[\left\{\mathrm{DPM}^{\mathrm{Anth}}\right\} \mathrm{BaN}\left(\mathrm{SiMe}_{3}\right)_{2}\right] \cdot{ }^{[93]}$ Deprotonation of the proligand with $\left[\mathrm{Ba}\left\{\mu-\mathrm{N}\left(\mathrm{SiMe}_{3}\right)_{2}\right\}\left\{\mathrm{N}\left(\mathrm{SiMe}_{3}\right)_{2}\right\}\right]_{2}$ provided the heteroleptic complex in $84 \%$ yield as dark red, fluorescent blocks (Figure 13). The complex is stabilised by $\mathrm{Ba} \cdots \pi$ arene interactions with the anthracenes, with a short $\mathrm{Ba} \cdots \mathrm{C}(\pi)$ distance of 3.002(9) $\AA$. Yet, the complex decomposes at $100{ }^{\circ} \mathrm{C}$, albeit not to homoleptic species; in fact, when attempted, the synthesis of $\left[\left\{\mathrm{DPM}^{\mathrm{Anth}}\right\}_{2} \mathrm{Ba}\right]$ could not be enforced. The presence of the flanking polyaromatics was deemed important, as when these groups were replaced with 2,6diisopropylphenyl substituents, the ligand was more weakly bound than in $\left[\left\{\mathrm{BDI}^{\mathrm{DiPP}}\right\} \mathrm{BaN}\left(\mathrm{SiMe}_{3}\right)_{2}\right]$, thus indicating that the ligand $\left\{\mathrm{DPM}^{\mathrm{DiPP}}\right\}^{-}$would be unsuitable for barium chemistry. ${ }^{[94]}$

It has recently been reported that a bis(imino)carbazolate ligand $\left\{\mathrm{Carb}^{\mathrm{DiPP}}\right\}^{-}$has been used to stabilise a broad range of heteroleptic barium species including the first fluoride, silanide and stannylide species. ${ }^{\text {[95] }}$ The four-coordinate heteroleptic barium amide $\left[\left\{\mathrm{Carb}^{\mathrm{DiPP}}\right\} \mathrm{BaN}\left(\mathrm{SiMe}_{3}\right)_{2}\right]$ was synthesised in $92 \%$ yield from the protonolysis between $\left\{\mathrm{Carb}^{\mathrm{DiPP}}\right\} \mathrm{H}$ and $\left[\mathrm{Ba}\left\{\mu-\mathrm{N}\left(\mathrm{SiMe}_{3}\right)_{2}\right\}\left\{\mathrm{N}\left(\mathrm{SiMe}_{3}\right)_{2}\right\}\right]_{2}$. This complex is uniquely stable towards ligand scrambling in solution, as no redistribution was observed even after weeks at $60{ }^{\circ} \mathrm{C}$. The ligand was used to synthesise the first heteroleptic Ba-fluoride [ $\left(\left\{\operatorname{Carb}^{\mathrm{DiPP}}\right\} \mathrm{Ba}(\mu-\mathrm{F}) \text {.thf }\right)_{2} \cdot(\mu-$ thf)], using the fluorinating reagent $\mathrm{Me}_{3} \mathrm{SnF}$. This complex completes the series of heteroleptic heavier alkaline-earth fluorides, of which the $\mathrm{Ca}$ and $\mathrm{Sr}$ complexes were stabilised with the ubiquitous $\left\{\mathrm{BDI}^{\mathrm{DiPP}}\right\}^{-}$ ligand. ${ }^{[20,96]}$ The same ligand proved also efficient in stabilising the tetrelides $\left[\left\{\mathrm{Carb}^{\mathrm{DiPP}}\right\} \mathrm{BaE}(\mathrm{SiMe})_{3}\right.$.thf $]$ $(\mathrm{E}=\mathrm{Si}, \mathrm{Sn})$ via salt metathesis with either $\left[\mathrm{KSi}\left(\mathrm{SiMe}_{3}\right)_{3} \cdot(\text { thf })_{2}\right]$ or $\left[\mathrm{KSn}\left(\mathrm{SiMe}_{3}\right)_{3} \cdot(\mathrm{thf})_{n}\right]$. These compounds are the first and second examples of Ba-to-Sn (average Ba-Sn = 3.521(3) $\AA$ ) and Ba-to-Si bonds, respectively; the $\mathrm{Ba}-\mathrm{Si}$ interatomic distance (average $\mathrm{Ba}-\mathrm{Si}=3.403(4) \AA$ ) is shorter than in Ruhlandt- 
Senge's homoleptic $\left[\mathrm{Ba}\left\{\mathrm{Si}\left(\mathrm{SiMe}_{3}\right)_{3}\right)_{2} \cdot(\text { thf })_{4}\right]$ (average $\left.\mathrm{Ba}-\mathrm{Si}=3.440(9) \AA{ }^{\circ}\right){ }^{[97]}$ Bonding analysis by DFT computations showed the Ba-to-tetrel bonds to be essentially ionic, with only a small covalent contribution.

Superbulky $\beta$-diketiminate

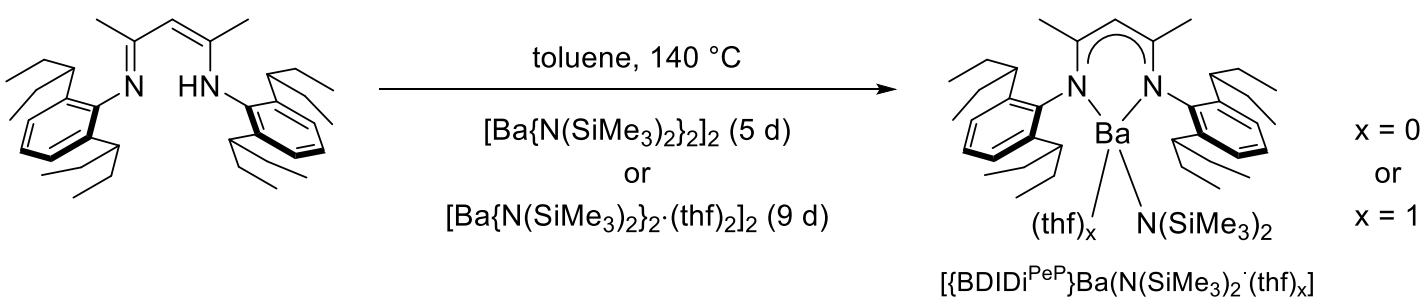

Dipyrromethenide ligand
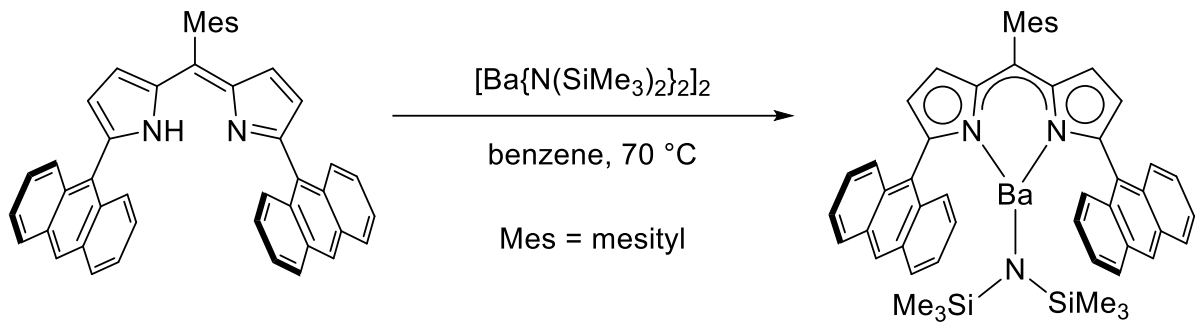

Bis(imino)carbazolate ligand
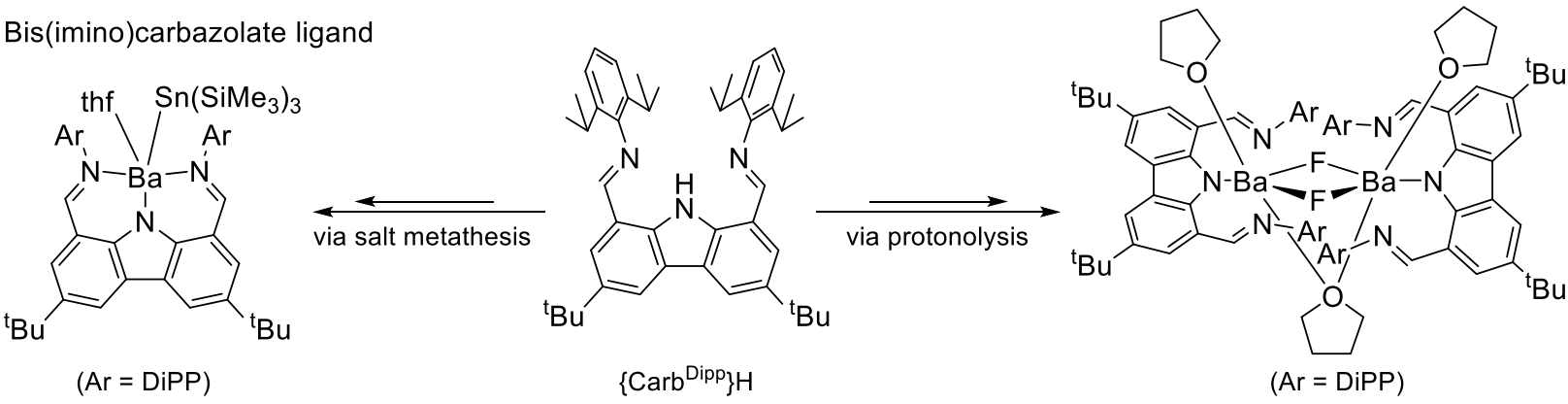

Bis(phosphinimino)methane ligand

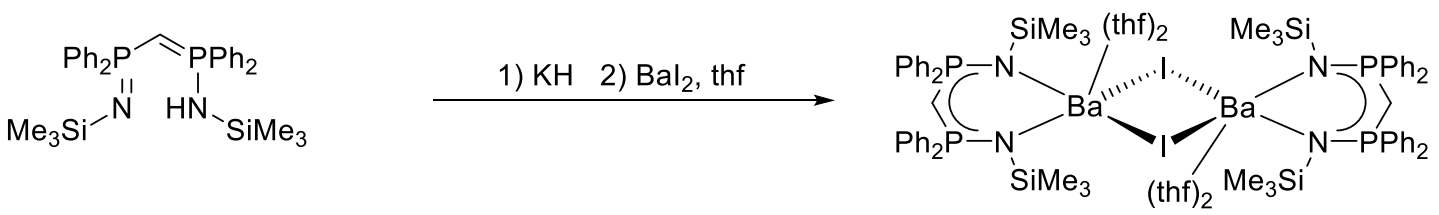

Figure 13. Syntheses of the heteroleptic complexes $\left[\left\{\mathrm{BDI}^{\mathrm{DiPeP}}\right\} \mathrm{BaN}\left(\mathrm{SiMe}_{3}\right)_{2} \cdot(\text { thf })_{\mathrm{x}}\right](\mathrm{x}=0$ or 1$){ }^{[29]}$ $\left[\left\{\mathrm{DPM}^{\mathrm{Anth}}\right\} \mathrm{BaN}\left(\mathrm{SiMe}_{3}\right)_{2}\right],{ }^{[93]}\left[\left\{\mathrm{CH}\left(\mathrm{Ph}_{2} \mathrm{P}=\mathrm{N}-\mathrm{SiMe}_{3}\right)_{2}\right\} \mathrm{Ba}(\mu-\mathrm{I}) \cdot(\text { thf })_{2}\right]_{2}{ }^{[98 \mathrm{~b}]}$ and complexes supported by the bis(imino)carbozate $\left\{\mathrm{Carb}^{\mathrm{DiPP}}\right\}^{-}{ }^{.}{ }^{[95]}$

Other monoanionic ligands sterically akin to $\beta$-diketiminates that were explored include the bis(phosphinimino)methanides $\quad\left\{\mathrm{CH}\left(\mathrm{Ph}_{2} \mathrm{P}=\mathrm{N}-\mathrm{Mes}\right)_{2}\right\}^{-}, \quad\left\{\mathrm{CH}\left(\mathrm{Ph}_{2} \mathrm{P}=\mathrm{N}-\mathrm{DiPP}\right)_{2}\right\}^{-} \quad$ and $\quad\left\{\mathrm{CH}\left(\mathrm{Ph}_{2} \mathrm{P}=\mathrm{N}-\right.\right.$ $\left.\left.\mathrm{SiMe}_{3}\right)_{2}\right\}^{-},{ }^{[98]}$ formed upon deprotonation of the bis(phosphinimino)methane parents. The heteroleptic iodobridged $\left[\left\{\mathrm{CH}\left(\mathrm{Ph}_{2} \mathrm{P}=\mathrm{N}-\mathrm{SiMe}_{3}\right)_{2}\right\} \mathrm{Ba}(\mu-\mathrm{I}) \cdot(\mathrm{thf})_{2}\right]_{2}$ was prepared from $\left\{\mathrm{CH}\left(\mathrm{Ph}_{2} \mathrm{P}=\mathrm{N}-\mathrm{SiMe}_{3}\right)_{2}\right\}^{-}$; the tridentate 
ligand generate a six-member metallacycle (see Figure 13) with a twist boat conformation and a short Ba-

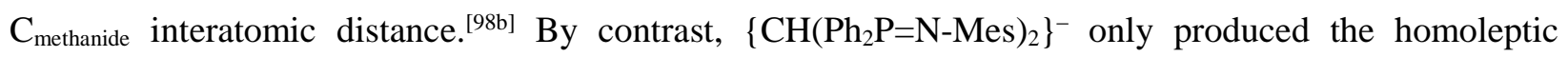
$\left[\left\{\mathrm{CH}\left(\mathrm{Ph}_{2} \mathrm{P}=\mathrm{N}-\mathrm{Mes}\right)_{2}\right\}_{2} \mathrm{Ba}\right]$, although it was able to produce stable heteroleptic calcium and strontium complexes. ${ }^{[98 a, 98 c]}$ In parenthesis, one may note that the dianionic bis(phosphinimino)methanediide $\left\{\mathrm{C}\left(\mathrm{Ph}_{2} \mathrm{P}=\mathrm{N}-\mathrm{DiPP}\right)_{2}\right\}^{2-}$ was used to obtain the monoligated $\left[\left\{\mathrm{C}\left(\mathrm{Ph}_{2} \mathrm{P}=\mathrm{N}-\mathrm{DiPP}\right\} \mathrm{Ba} \cdot(\text { thf })_{3}\right]\right.$ monomer, while $\left\{\mathrm{C}\left(\mathrm{Ph}_{2} \mathrm{P}=\mathrm{N}-\mathrm{SiMe}_{3}\right)_{2}\right\}^{2-}$ gave the dimeric $\left[\left\{\mathrm{C}\left(\mathrm{Ph}_{2} \mathrm{P}=\mathrm{N}-\mathrm{SiMe}_{3}\right\} \mathrm{Ba} \cdot \mathrm{thf}\right]_{2} \cdot{ }^{[98 \mathrm{~d}]}\right.$

The crown-ether functionalised iminoanilide $\left\{\operatorname{ImAn}^{\text {crown }}\right\}^{-}$and amidinate $\left\{\mathrm{Am}^{\text {crown }}\right\}^{-}$ligands have been used to obtain the amides $\left[\left\{\mathrm{ImAn}^{\text {crown }}\right\} \mathrm{BaN}\left(\mathrm{SiMe}_{2} \mathrm{H}\right)_{2}\right]$ and $\left[\left\{\mathrm{Am}^{\text {crown }}\right\} \mathrm{BaN}\left(\mathrm{SiMe}_{2} \mathrm{H}\right)_{2}\right]$ (Figure 14) ${ }^{[44]}$ Both complexes contain intramolecular $\mathrm{Ba} \cdots \mathrm{H}-\mathrm{Si}$ anagostic interactions, although these were thought to be weak based on the structural solid-state and ${ }^{1} \mathrm{H}$ solution NMR data. Interestingly, for $\left[\left\{\mathrm{Am}^{\text {crown }}\right\} \mathrm{BaN}\left(\mathrm{SiMe}_{2} \mathrm{H}\right)_{2}\right]$, the molecular structure showed the amidinate was bound in a $\kappa^{1}$ monodentate fashion the barium atom (much more common with oxophilic metals is the bidentate $\kappa^{2}$-coordination, while the bridging $\mu, \kappa^{2}-$ binding mode is only found in dinuclear complexes of middle and especially late transition metals), with the second imine nitrogen orientated away from the metal; this is likely the outcome of excessive steric crowding in the ligand backbone, even for a large metal such as barium. Although this has been seen in a calcium-hydride amidinate complex, that latter complex featured stabilising $\pi$ interactions between the Caatom and a flanking DiPP group, ${ }^{[99]}$ a phenomenon not encountered in $\left[\left\{\mathrm{Am}^{\text {crown }}\right\} \mathrm{BaN}\left(\mathrm{SiMe}_{2} \mathrm{H}\right)_{2}\right]$.
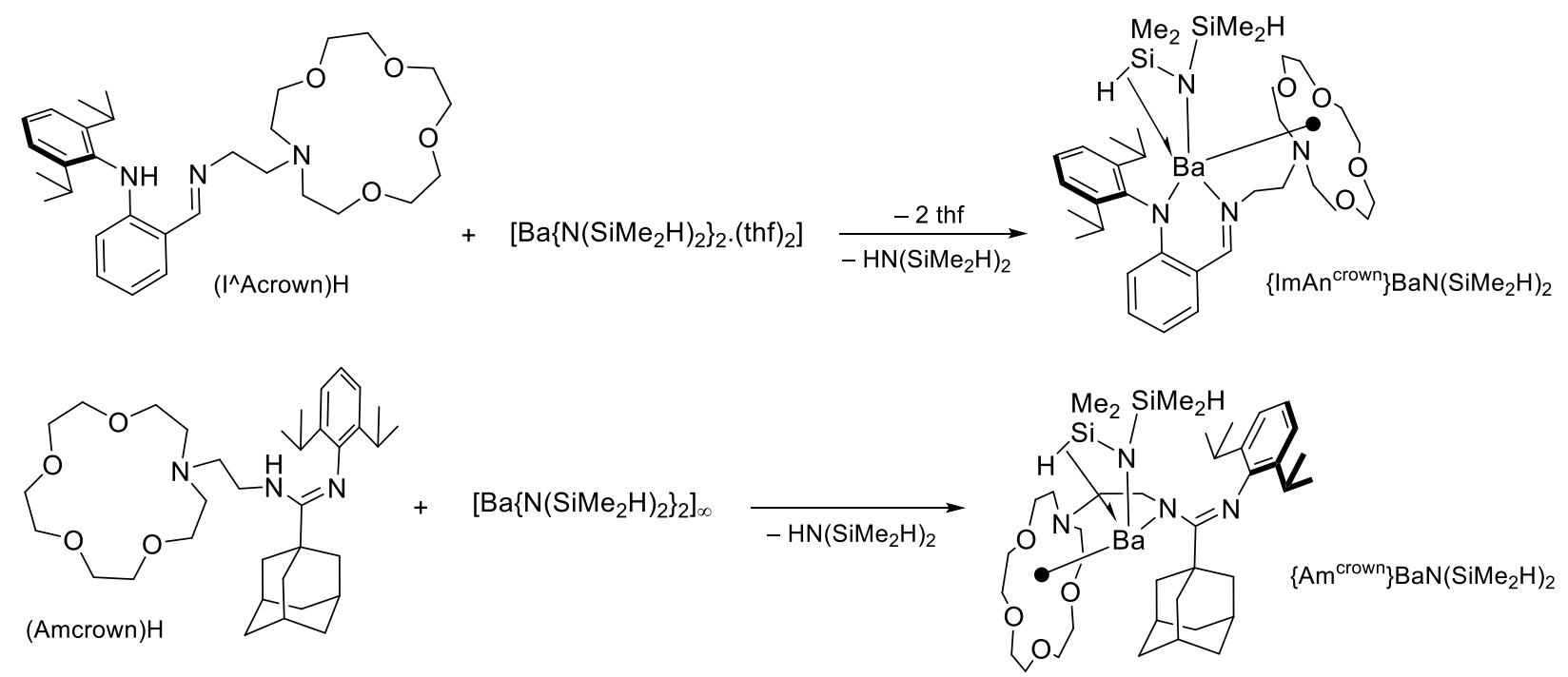

Figure 14. Barium iminoanilide and amidinate heteroleptic complexes with aza-crownether tethers. ${ }^{[44]}$ Black dots indicate all heteroatoms are metal-bound. 


\section{Other monoanionic ligands}

Although the majority of ligands used to synthesise heteroleptic barium complexes are chelating amides, other types of ligand systems have been used to generate isolable complexes. Tris(pyrazolyl)hydroborate (Tp) ligands have been utilised to stabilise barium heteroleptic amides, as well as other complexes with coligands such a hydrides, alkyls and iodides. ${ }^{[100]}$ The first heteroleptic barium amide supported with a Tp ligand was reported using the $\left\{\mathrm{Tp}^{\mathrm{Me}, \mathrm{Me}}\right\}^{-}$ligand. ${ }^{[101]}$ The synthesis, outlined in Figure 15 , highlights the importance of the choice of coligand as well as the ancillary ligand, as while the heteroleptic amide complex $\left[\left\{\mathrm{Tp}^{\mathrm{Me}, \mathrm{Me}}\right\} \mathrm{BaN}\left(\mathrm{SiMe}_{3}\right)_{2} \cdot(\mathrm{thf})_{2}\right]$ was stable in solution at room temperature, the in situ generated $\left[\left\{\mathrm{Tp}^{\mathrm{Me}, \mathrm{Me}}\right\} \mathrm{Ba}\left(\mathrm{AlEt}_{4}\right)\right]$ was not able to prevent redistribution to the homoleptic complex $\left[\left\{\mathrm{Tp}^{\mathrm{Me}, \mathrm{Me}}\right\}_{2} \mathrm{Ba}\right]$.

More recently, tris(3-adamantyl-5-isopropyl-pyrazolyl)hydroborate $\left(=\left\{\mathrm{Tp}^{\mathrm{Ad}, \mathrm{PPr}}\right\}^{-}\right)$has enabled the stabilisation of the Ba-alkyl $\left[\left\{\mathrm{Tp}^{\mathrm{Ad}, i \mathrm{Pr}}\right\} \mathrm{BaCH}\left(\mathrm{SiMe}_{3}\right)_{2} \cdot \mathrm{thf}\right]$, obtained via protonolysis between $\left[\mathrm{Ba}\left\{\mathrm{CH}\left(\mathrm{SiMe}_{3}\right)_{2}\right\} \cdot(\mathrm{thf})_{2}\right]$ and $\left\{\mathrm{Tp}^{\mathrm{Ad}, i \mathrm{Pr}}\right\} \mathrm{H}$. It was subsequently used to obtain the first heteroleptic barium hydride, $\left[\left\{\mathrm{Tp} \mathrm{p}^{\mathrm{Ad}, i \mathrm{Pr}}\right\} \mathrm{Ba}(\mu-\mathrm{H})\right]_{2}$ upon hydrogenolysis at $20 \mathrm{~atm}$ (Figure 15$) .{ }^{[102]}$ As per the lighter calcium and strontium hydrides, discrete barium hydrides had long been sought owing to their suspected high reactivity and role in catalytic manifolds; ${ }^{[103]}$ yet, $\left[\left\{\mathrm{Tp}^{\mathrm{Ad}, i \mathrm{Pr}}\right\} \mathrm{Ba}(\mu-\mathrm{H})\right]_{2}$ was only obtained in 2017 , over ten years after the discovery of the first molecular calcium hydride. ${ }^{[19]}$ The disclosure of strontium hydrides was concomitant with that for barium, ${ }^{[104]}$ highlighting the growing difficulty in stabilising these reactive species as metal size and ionicity of the bonding increase. While a good hydrogenation catalyst, $\left[\left\{\mathrm{Tp}^{\mathrm{Ad}, i \mathrm{Pr}}\right\} \mathrm{Ba}(\mu-\right.$ $\mathrm{H})]_{2}$ also readily reacted with $\mathrm{CO}$ to afford the dimeric complex $\left[\left\{\mathrm{Tp}^{\mathrm{Ad}, i \mathrm{Pr}}\right\} \mathrm{Ba}_{2}(\mu\right.$-cis-OCH=CHO$\left.)\right]$, bridged by the dianionic ${ }^{-} \mathrm{O}-\mathrm{CH}=\mathrm{CH}-\mathrm{O}^{-}$ethenediolate, following a sequence of insertion steps. 


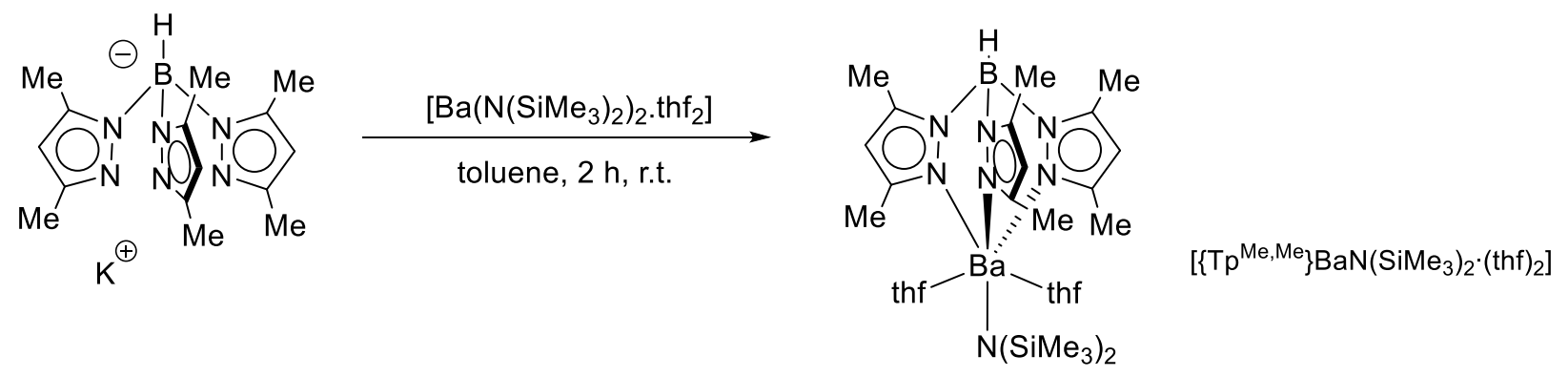

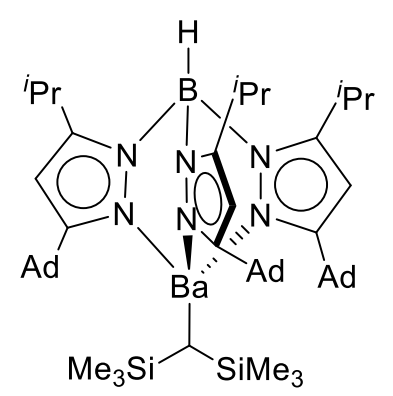

$\left[\left\{\mathrm{Tp}^{\mathrm{Ad}, \mathrm{Pr}}\right\} \mathrm{BaCH}\left(\mathrm{SiMe}_{3}\right)_{2} \cdot \mathrm{thf}\right]$

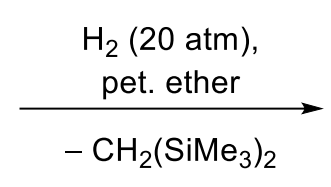

$1 / 2$

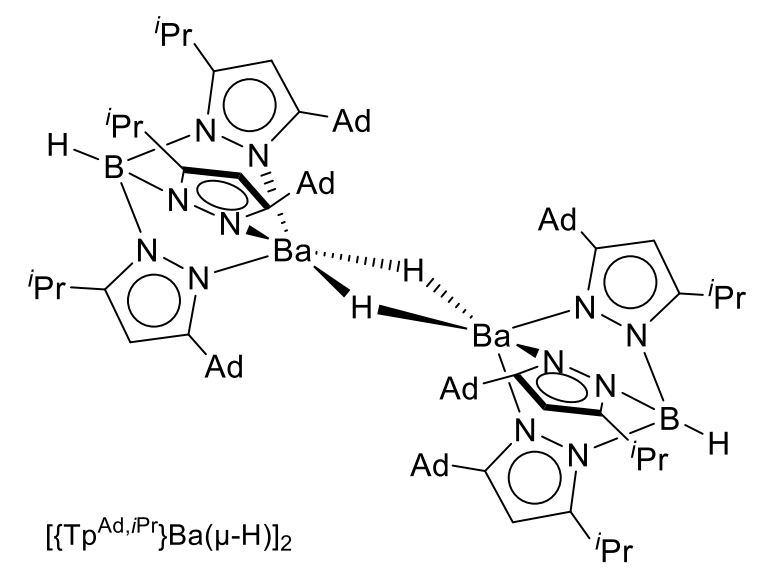

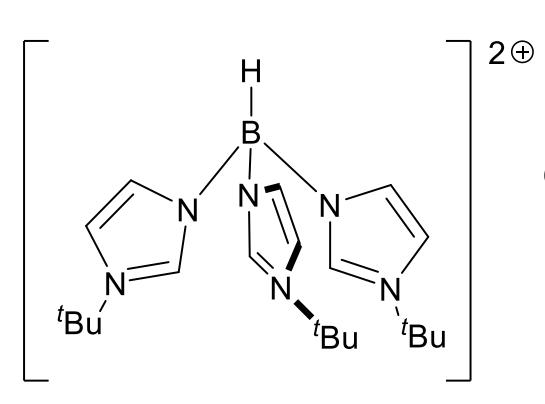
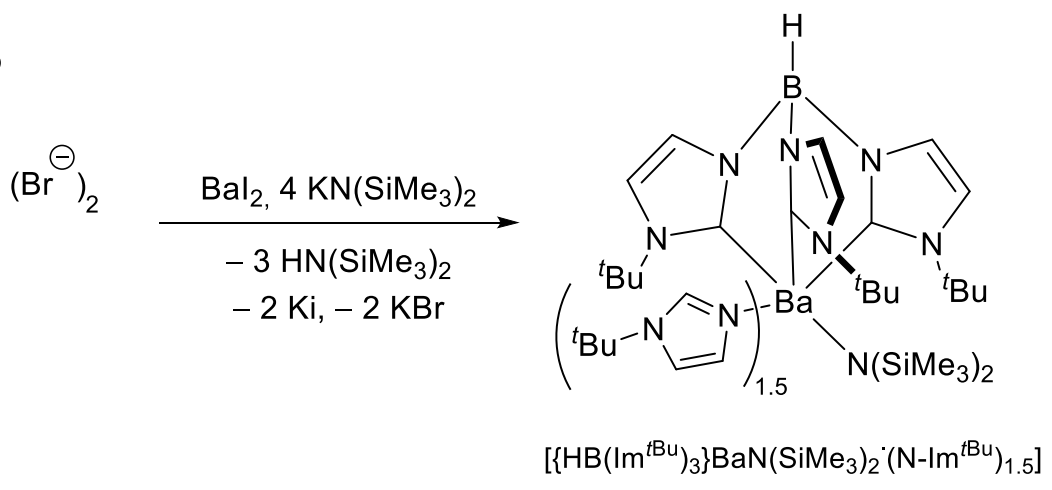

Figure 15. Heteroleptic barium complexes supported by hydroborates. ${ }^{[101-102,105]} \mathrm{Ad}=1$-adamantyl.

The tris(imidazoline-2ylidene-1-yl)hydroborate $\left\{\mathrm{HB}\left(\operatorname{Im}^{t} \mathrm{Bu}\right)_{3}\right\}^{-}$has been used to stabilise the heteroleptic $\left[\left\{\mathrm{HB}\left(\mathrm{Im}^{t \mathrm{Bu}}\right)_{3}\right\} \mathrm{BaN}\left(\mathrm{SiMe}_{3}\right)_{2} \cdot\left(\mathrm{N}-\mathrm{Im}^{t \mathrm{Bu}}\right)_{1.5}\right] \cdot{ }^{[105]}$ The complex was synthesised via the one-pot salt metathesis reaction between $\mathrm{BaI}_{2}, 4$ equivalents of $\left[\mathrm{KN}\left(\mathrm{SiMe}_{3}\right)_{2}\right]$ and $\left[\mathrm{HB}\left(\mathrm{Im}{ }^{t} \mathrm{Bu}\right)_{3}\right][\mathrm{Br}]_{2}$ in thf at $-78{ }^{\circ} \mathrm{C}$ (Figure 15). The ligand is an interesting variation on the more commonly used Tp ligands, with similar steric, kinetic, electronic and solubility profiles. Interestingly, the solid-state data contained two molecules of the heteroleptic amide in the unit-cell with different numbers of coordinating imidazoles, one with one molecule of 1-tert-butylimidazole, and the other with two. These coordinating imidazoles are generated in the course of the reaction upon fragmentation of the proligand. 
The bulky cyclopentadienyl ligands $\left\{\mathrm{Cp}^{\mathrm{Ar}}\right\}^{-}$and $\left\{\mathrm{Cp}^{\mathrm{Ar}}\right\}^{-}$(where $\mathrm{Ar}{ }^{\prime}=3,5-{ }^{i} \mathrm{Pr}_{2}-\mathrm{C}_{6} \mathrm{H}_{3}$ and $\mathrm{Ar} "=3,5-$ $\left.{ }^{t} \mathrm{Bu}_{2}-\mathrm{C}_{6} \mathrm{H}_{3}\right)$ have afforded the monomeric $\left[\left\{\mathrm{Cp}^{\mathrm{Ar}}\right\} \mathrm{BaCH}\left(\mathrm{SiMe}_{3}\right)_{2} \cdot\left(\mathrm{thf}_{2}\right]\right.$ and $\left[\left\{\mathrm{Cp}^{\mathrm{Ar}}\right\} \mathrm{BaCH}\left(\mathrm{SiMe}_{3}\right)_{2} \cdot \mathrm{thf}\right]$ (Figure 16). The hydride dimers $\left[\left\{\mathrm{Cp}^{\mathrm{Ar}}\right\} \mathrm{Ba}(\mu-\mathrm{H}) \cdot \mathrm{dabco}_{2}\right.$ and $\left[\left\{\mathrm{Cp}^{\mathrm{Ar}}\right\} \mathrm{Ba}(\mu-\mathrm{H}) \cdot \text { thf }\right]_{2}$ were obtained through hydrogenolysis of their respective alkyl precursors, preceded by treatment with dabco in hexane for the former ${ }^{[55]}$ The two hydride complexes display slightly different stability and reactivity. $\left[\left\{\mathrm{Cp}^{\mathrm{Ar}}\right\} \mathrm{Ba}(\mu-\right.$ $\mathrm{H}) \cdot$ dabco $_{2}$ is kinetically unstable in ethereal solvents, redistributing to the homoleptic $\left[\left\{\mathrm{Cp}^{\mathrm{Ar}}\right\}_{2} \mathrm{Ba}\right]$ in thf, while the more sterically shielded $\left[\left\{\mathrm{Cp}^{\mathrm{Ar}}\right\} \mathrm{Ba}(\mu-\mathrm{H}) \cdot \text { thf }\right]_{2}$ is stable towards ligands scrambling. These bulky ligands also enabled the synthesis of $\mathrm{Ca}$ and $\mathrm{Sr}$ - hydrides. Both barium hydrides are highly reactive, decomposing in aromatic solvents, but are stable in aliphatic solvents. Complex $\left[\left\{\mathrm{Cp}^{\mathrm{Ar}}\right\} \mathrm{Ba}(\mu-\mathrm{H}) \cdot \mathrm{dabco}\right]_{2}$ catalysed hydrogenation reactions, the results of which are discussed elsewhere in this review.
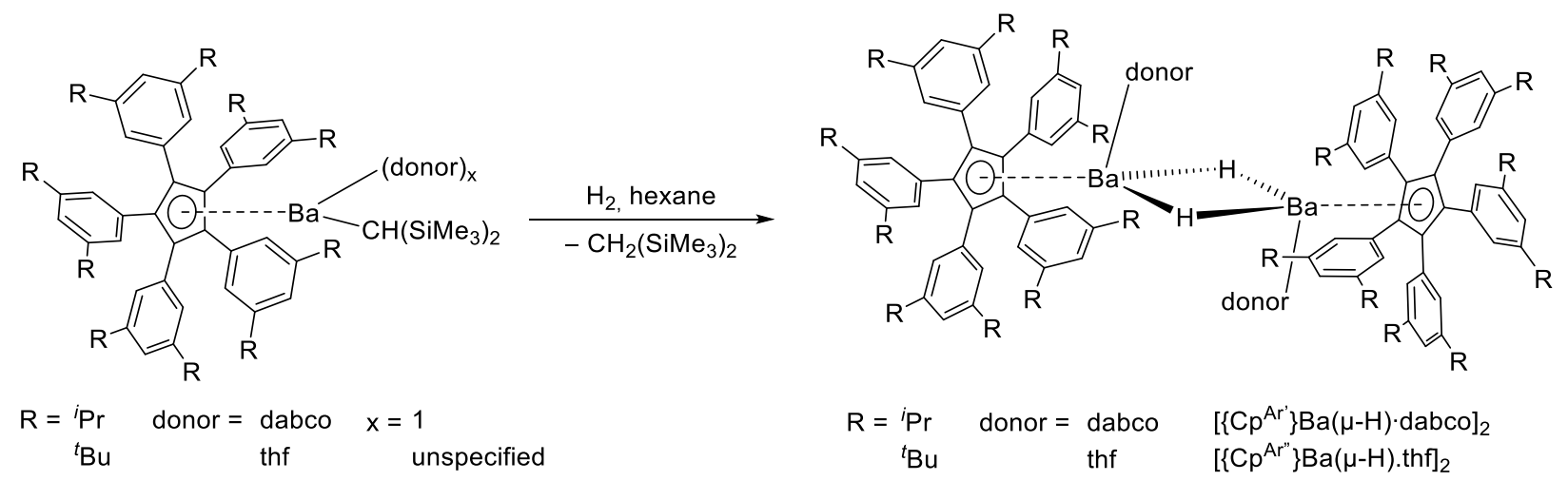

Figure 16. Barium hydride synthesis using bulky cyclopentadienyl ligands. ${ }^{[55]}$

With respect to the large number of barium phenolates collated in the CSD database (>200, most of them being heterobimetallic homoligated compounds $)^{[106]}$ O-bound ligands such as phenolates and, a fortiori, alkoxides, have seldom been used to generate discrete heteroleptic barium complexes; most were already reported over a decade ago. A few stable charge-neutral barium amides bearing multidentate aminoetherphenolates have been shown to catalyse the ring-opening polymerisation of cyclic esters. ${ }^{[42,75]}$ Monocationic barium complexes paired with the weakly coordinated anion $\left[\mathrm{H}_{2} \mathrm{~N}\left\{\mathrm{~B}\left(\mathrm{C}_{6} \mathrm{~F}_{5}\right)_{2}\right\}_{2}\right]^{-}$were also able to promote ROP catalysis. ${ }^{[75,107]}$ On the whole, in comparison with monoanionic nitrogen ligands, the number of O-based ligands suited to preparation of heteroleptic barium species remains limited. Notable compounds highlighted in Figure 17 include the phenolates $\left[\left\{\mathrm{LO}^{\text {crown }}\right\} \mathrm{BaN}\left(\mathrm{SiMe} \mathrm{H}_{2} \mathrm{H}\right)_{2}\right]$ and its charge separated analogue $\left[\left\{\mathrm{LO}^{\text {crown }}\right\} \mathrm{Ba} \cdot(\text { thf })_{2}\right] \cdot\left[\mathrm{H}_{2} \mathrm{~N}\left\{\mathrm{~B}\left(\mathrm{C}_{6} \mathrm{~F}_{5}\right)_{3}\right\}_{2}\right]$, as well as the fluoroalkoxide ion pair $\left[\left\{\mathrm{RO}^{\text {crown }}\right\} \mathrm{Ba}(\text { thf })_{2}\right] \cdot\left[\mathrm{H}_{2} \mathrm{~N}\left\{\mathrm{~B}\left(\mathrm{C}_{6} \mathrm{~F}_{5}\right)_{3}\right\}_{2}\right]$. The charge-neutral $\left[\left\{\mathrm{RO}^{\text {crown }}\right\} \mathrm{BaN}\left(\mathrm{SiMe}_{2} \mathrm{R}\right)_{2}\right](\mathrm{R}=\mathrm{H}$, Me $)$ were prone to ligand redistribution in solution and could not be isolated cleanly. 


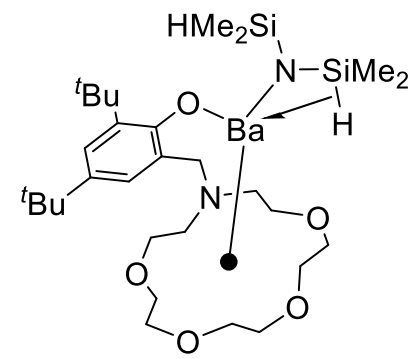

$\left[\left\{\mathrm{LO}^{\text {crown }}\right\} \mathrm{BaN}\left(\mathrm{SiMe}_{2} \mathrm{H}\right)_{2}\right]$

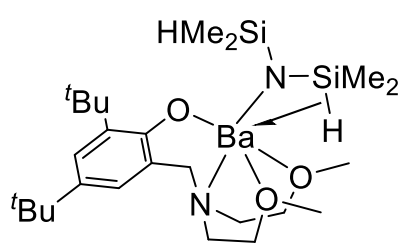

$\left[\left\{\mathrm{LO}^{\mathrm{OMe}}\right\} \mathrm{BaN}\left(\mathrm{SiMe}_{2} \mathrm{H}\right)_{2}\right]$

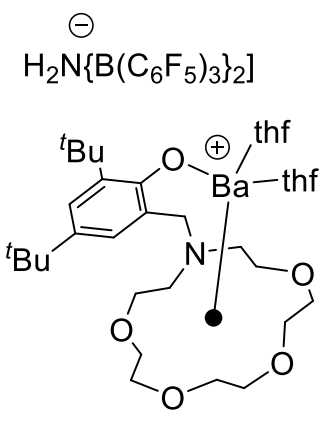

$\left[\left\{\mathrm{LO}^{\text {crown }}\right\} \mathrm{Ba} \cdot(\text { thf })_{2}\right]^{+}$ $\left[\mathrm{H}_{2} \mathrm{~N}\left\{\mathrm{~B}\left(\mathrm{C}_{6} \mathrm{~F}_{5}\right)_{3}\right\}_{2}\right]^{-}$
$\Theta$ $\left.\mathrm{H}_{2} \mathrm{~N}\left\{\mathrm{~B}\left(\mathrm{C}_{6} \mathrm{~F}_{5}\right)_{3}\right\}_{2}\right]$<smiles>FC(F)(F)C1(C(F)(F)F)COCOCCOCCOCC[N+]12[B]O[B]2</smiles>

$\left[\left\{\mathrm{RO}^{\text {crown }}\right\} \mathrm{Ba}\right]^{+}$

$\left[\mathrm{H}_{2} \mathrm{~N}\left\{\mathrm{~B}\left(\mathrm{C}_{6} \mathrm{~F}_{5}\right)_{3}\right\}_{2}\right]^{-}$

Figure 17. Molecular barium phenolates and fluoroalkoxides. ${ }^{[42,75,107]}$ Black dot indicates all heteroatoms are metal-bound.

\section{Other types of ligands}

In recent years, few molecular barium compounds other than those supported by the monoanionic ligands described above have been under to the spotlight. However, two particular unusual examples must be highlighted. A remarkable case of barium hydride, the heptanuclear cluster "ligand-free" $\left[\mathrm{Ba}_{7} \mathrm{H}_{7}\left\{\mathrm{~N}\left(\mathrm{SiMe}_{3}\right)_{2}\right\}_{7} \cdot\left(\mathrm{C}_{6} \mathrm{H}_{6}\right)_{2}\right]$, was unveiled in 2017 (Figure 18). ${ }^{[33]}$ This very soluble complex, not supported by a bulky or multidentate ligand, was simply prepared reproducibly in ca. $50 \%$ yields by reaction of $\left[\mathrm{Ba}\left\{\mu-\mathrm{N}\left(\mathrm{SiMe}_{3}\right)_{2}\right\}\left\{\mathrm{N}\left(\mathrm{SiMe}_{3}\right)_{2}\right\}\right]_{2}$ with $\mathrm{PhSiH}_{3}$ in toluene, followed by recrystallisation from benzene. At $95{ }^{\circ} \mathrm{C}$, no coalescence of hydride signals is observed by ${ }^{1} \mathrm{H}$ NMR in benzene- $d_{6}$, although the cluster slowly decomposes to unidentified hydride species. The cluster is a very strong reducing agent, much stronger that $\left[\mathrm{LiAlH}_{4}\right]$, and already under mild conditions $\left(20{ }^{\circ} \mathrm{C}, 1 \mathrm{bar}\right)$ it reduces $\mathrm{Me}_{3} \mathrm{SiCH}=\mathrm{CH}_{2}$, norbornadiene, and even non-activated double bonds, such as ethylene. It is also extremely basic, deprotonating poorly acidic methyl groups in hexamethyldisilazide to generate the dianionic ligand $\left(\mathrm{Me}_{3} \mathrm{Si}\right)\left(\mathrm{Me}_{2} \mathrm{SiCH}_{2}^{-}\right) \mathrm{N}^{-}$, as seen in the molecular solid-state structure of the cluster $\left[\mathrm{Ba}_{14} \mathrm{H}_{12}\left\{\mathrm{~N}\left(\mathrm{SiMe}_{3}\right)_{2}\right\}_{8}\left\{(\mathrm{Me} 3 \mathrm{Si})\left(\mathrm{Me}_{2} \mathrm{SiCH}_{2}\right) \mathrm{N}\right\}_{4}\right]$.

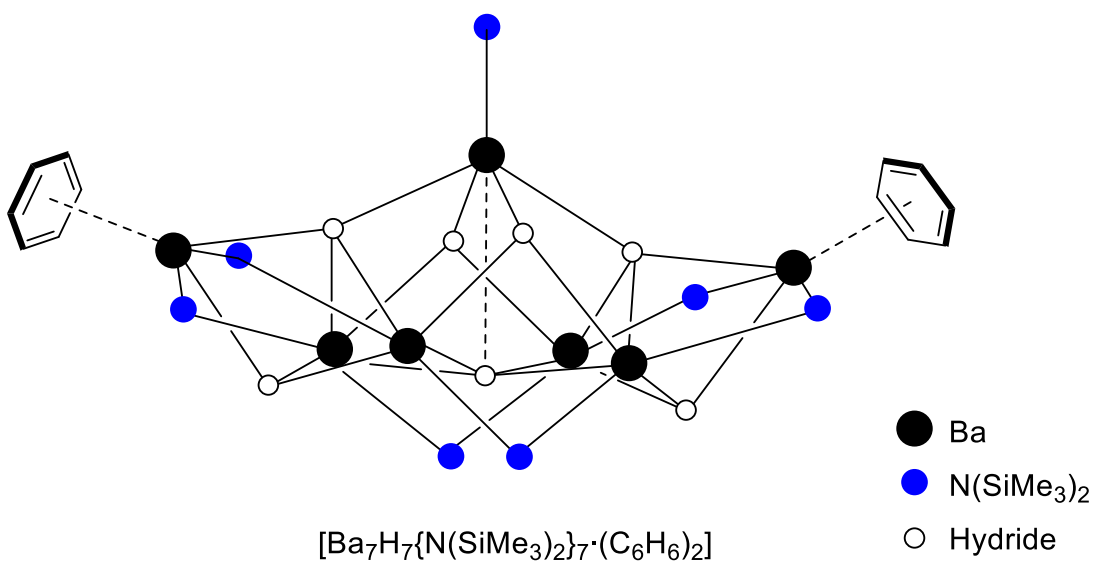

Figure 18. Sketch of the molecular structure of $\left[\mathrm{Ba}_{7} \mathrm{H}_{7}\left\{\mathrm{~N}\left(\mathrm{SiMe}_{3}\right)_{2}\right\}_{7} \cdot\left(\mathrm{C}_{6} \mathrm{H}_{6}\right)_{2}\right]{ }^{[33]}$ 
Redox non-innocent 1,4-diaza-1,3-dienes constitute a well-known class of proligands amenable to single or double reduction to generate radical-monoanions and dianionic enediamides, respectively. As such, it is not surprising that they have been used in combination with the highly reducing alkali and alkaline-earth metals. The potassium salt of $N, N^{\prime}$-bis(2,6-diisopropyl-phenyl)-1,4-diaza-1,3-butadiene (= $\mathrm{DAD}^{\mathrm{DiPP}}$ ) reacted with $\mathrm{BaI}_{2}$ upon elimination of $\mathrm{KI}$ to afford the structurally unusual iodide-bridged heterobimetallic dimer $\left[\left\{\mathrm{K}\left(\mathrm{DAD}^{\mathrm{DiPP}}\right) \cdot(\operatorname{thf})_{2}\right\}\left\{\mathrm{Ba}(\mu-\mathrm{I}) \cdot(\mathrm{thf})_{2}\right\}\right]_{2}$, bearing the twice reduced enediamide dianion $\left\{\mathrm{DAD}^{\mathrm{DiPP}}\right\}^{2-}$ (Figure 19). ${ }^{[108]}$ The red diamagnetic complex was characterised by NMR spectroscopy. By contrast, direct metalation/reduction of $\mathrm{DAD}^{\mathrm{DiPP}}$ with elemental barium in the presence of iodine generated low yields of the homometallic complex $\left[\mathrm{Ba}\left(\mathrm{DAD}^{\mathrm{DiPP}}\right)(\mu-\mathrm{I}) \cdot(\text { thf })_{2}\right]_{2}$. This dark red paramagnetic compound could not be analysed by NMR. The data recorded by EPR spectroscopy were consistent with free radicals in organic species, indicating the presence of an unpaired electron chiefly situated in the backbone of the monoanionic $\left\{\mathrm{DAD}^{\mathrm{DiPP}}\right\}^{-}$ligands. These ligands could be further reduced to the dianionic $\left\{\mathrm{DAD}^{\mathrm{DiPP}}\right\}^{2-}$ by reaction with elemental potassium, giving $\left[\left\{\mathrm{K}\left(\mathrm{DAD}{ }^{\mathrm{DiPP}}\right) \cdot(\text { thf })_{2}\right\}\{\mathrm{Ba}(\mu-\right.$ $\left.\left.\mathrm{I}) \cdot(\text { thf })_{2}\right\}\right]_{2}$ in high yields. In another study, ${ }^{[109]} \mathrm{DAD}^{\mathrm{DiPP}}$ was found to react with excess elemental Ba in dme to afford the doubly ligated diamagnetic $\left[\left\{\mathrm{DAD}^{\mathrm{DipP}}\right\}_{2} \mathrm{Ba} \cdot \mathrm{dme}\right]$ in very high yield, without trace of contamination by the Ba-enediamide derivative. This complex proved able to transfer the ligands from barium to a holmium precursor and generate a new Ho-based radical-anion complex in clean fashion. In a related study, ${ }^{\mid 110]}$ the heavily substituted 2,3-dimethyl-1,4-bis(2,4-dimethylphenyl)-1,3-butadiene reacted with elemental barium and catalytic iodine in thf to afford purple crystals of the diamagnetic monomer [Ba\{2,3-dimethyl-1,4-bis(2,4-dimethylphenyl)-2-butenediide]·(thf) 4 ].

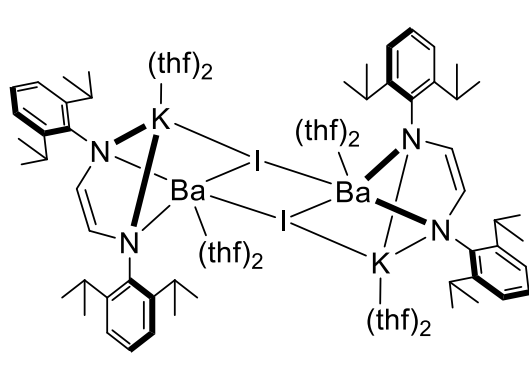

$\left[\left\{K\left(\operatorname{DAD}{ }^{\mathrm{DiPP}}\right) \cdot(\text { thf })_{2}\right\}\left\{\mathrm{Ba}(\mu-\mathrm{l}) \cdot(\text { thf })_{2}\right\}\right]_{2}$

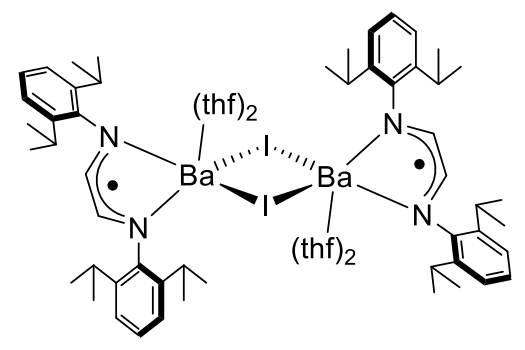

$\left[\mathrm{Ba}\left(\operatorname{DAD}{ }^{\mathrm{DiPP}}\right)(\mu-1) \cdot(\text { thf })_{2}\right]_{2}$

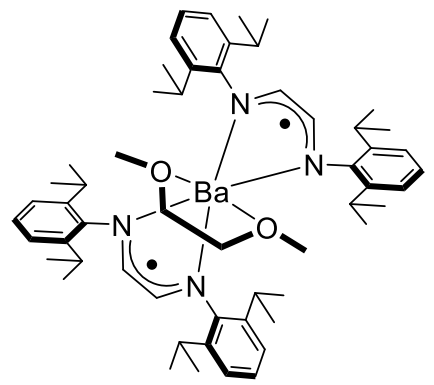

$\left[\left(\mathrm{DAD}{ }^{\mathrm{Dipp}}\right)_{2} \mathrm{Ba} \cdot \mathrm{dme}\right]$

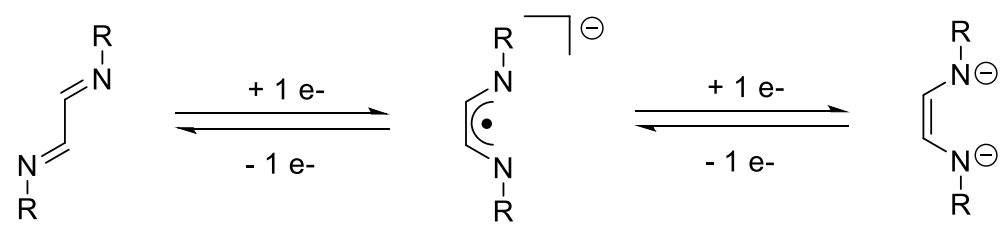

Figure 19. $N, N^{\prime}$-bis(2,6-diisopropyl-phenyl)-1,4-diaza-1,3-butadiene and barium complexes. ${ }^{[108-109]}$ 


\section{Barium-mediated homogeneous catalysis}

Many of the aforementioned barium complexes were designed to be catalysts or precatalysts in reactions as varied as hydroelementation, ${ }^{[43,61]}$ imine $^{[62]}$ or alkene ${ }^{[63]}$ hydrogenation, and dehydrocoupling of amines with hydrosilanes ${ }^{[64]}$ or boranes. ${ }^{[65]}$ There are several reviews on alkaline-earth mediated homogenous catalysis that the reader is directed to for more thorough discussion of this topic. ${ }^{[1-5,111]}$, Here, recent examples in which $\mathrm{Ba}$ (pre)catalysts have been particularly effective are highlighted. Alkaline-earth and barium catalysis, unlike catalysis with the transition metals, is redox-neutral, being constrained to only the +2 oxidation state. The reactivity of the $[\mathrm{Ba}]-\mathrm{Y}$ bond in a catalytically active species is rationalised by the difference in electronegativity between the electropositive $\mathrm{Ba}$ and more electronegative $\mathrm{Y}$ atom(s) (where $\mathrm{Y}=\mathrm{H}$ or a p-block element, e.g. C, N, O or P), such that the 2-electron ${ }^{\delta+} \mathrm{Ba}^{-} \mathrm{Y}^{\delta-} \sigma$ bond is always polarised negatively towards the more electronegative $\mathrm{Y}$ atom. Although the charge distribution in the Ba-Y bond is relative, depending on the nature of the $\mathrm{Y}$ substituent, the highly polarised nature of this interaction limits the reactivity with another $\sigma$-bonded, polarised substrate ${ }^{\delta} H-Z^{\delta+}$ to $2 \sigma-2 \sigma$ exchange of electron density. This exchange can be rationalised as a $\sigma$-bond metathesis progressing through a highly organised and polarised 4-membered transition state (Figure 20, bottom). ${ }^{[5,112]}$ The outcome of the reaction is governed by the polarisation of the ${ }^{\delta+} \mathrm{Ba}-\mathrm{Y}^{\delta-}$ bond, as the more electronegative hydride in the polarised ${ }^{\delta-} \mathrm{H}-\mathrm{Z}^{\delta+}$ substrate will take up the position $\alpha$ to barium in the corresponding 4-membered transition state. The combination of both 'protic' and 'hydridic' $\sigma$-bond metathesis steps for the dehydrocoupling of ${ }^{\delta+} \mathrm{H}-\mathrm{Y}^{\delta^{-}}$and ${ }^{\delta-} \mathrm{H}-\mathrm{Z}^{\delta+}$ prepolarised substrates (e.g. $\mathrm{HNEt}_{2}$ and $\mathrm{HSiPh}_{3}$, respectively) has been used for the construction of a range of Y-Z bonds. However, this reactivity is, for now, limited to these pre-polarised protic or hydridic elementto-hydrogen bonds. It must be noted that depending on the identity and intrinsic reactivity of the substrates $\mathrm{H}-\mathrm{Y}$ and H-Z, the catalytic manifold can be entered in two different ways from the precatalyst $[\{\mathrm{L}\} \mathrm{Ba}-\mathrm{X}]$.

The $[\mathrm{Ba}]-\mathrm{Y}$ bond of the active species can also induce polarised insertion into multiply bonded substrates, such as ketones, imines and, most typically, unsaturated C-C bonds (Figure 20, top). Although whether the reaction occurs is influenced by the thermodynamics of the relative energy of all broken and formed bonds, the kinetic feasibility of any given transformation relies on the substrates ability to stabilise the charge separation induced in the 4-membered transition state. Again, an element of directionality is conferred from barium: in pre-polarised substrates such as ketones or imines, the more electronegative atom will pre-coordinate to barium, resulting in it being in the $\alpha$ position to the metal in the eventual fourmembered transition state. This will control the regiochemistry of the whole insertive process. In contrast, non-polar unsaturated bonds such as alkenes and alkynes, polarisation of the $\pi$-electrons is induced by the [Ba]-Y unit itself. ${ }^{[13]}$

The following sections are a survey of the recent accounts of alkaline-earth mediated catalysis, with a focus on the performances of barium (pre)catalysts with respect to the lighter metals. The literature for Ae- 
promoted homogeneous polymerisation catalysis was surveyed on multiple occasions in the years leading to $2016,{ }^{[1-4,114]}$ and has not witnessed major breakthroughs since; ${ }^{[5]}$ it is not discussed further below.
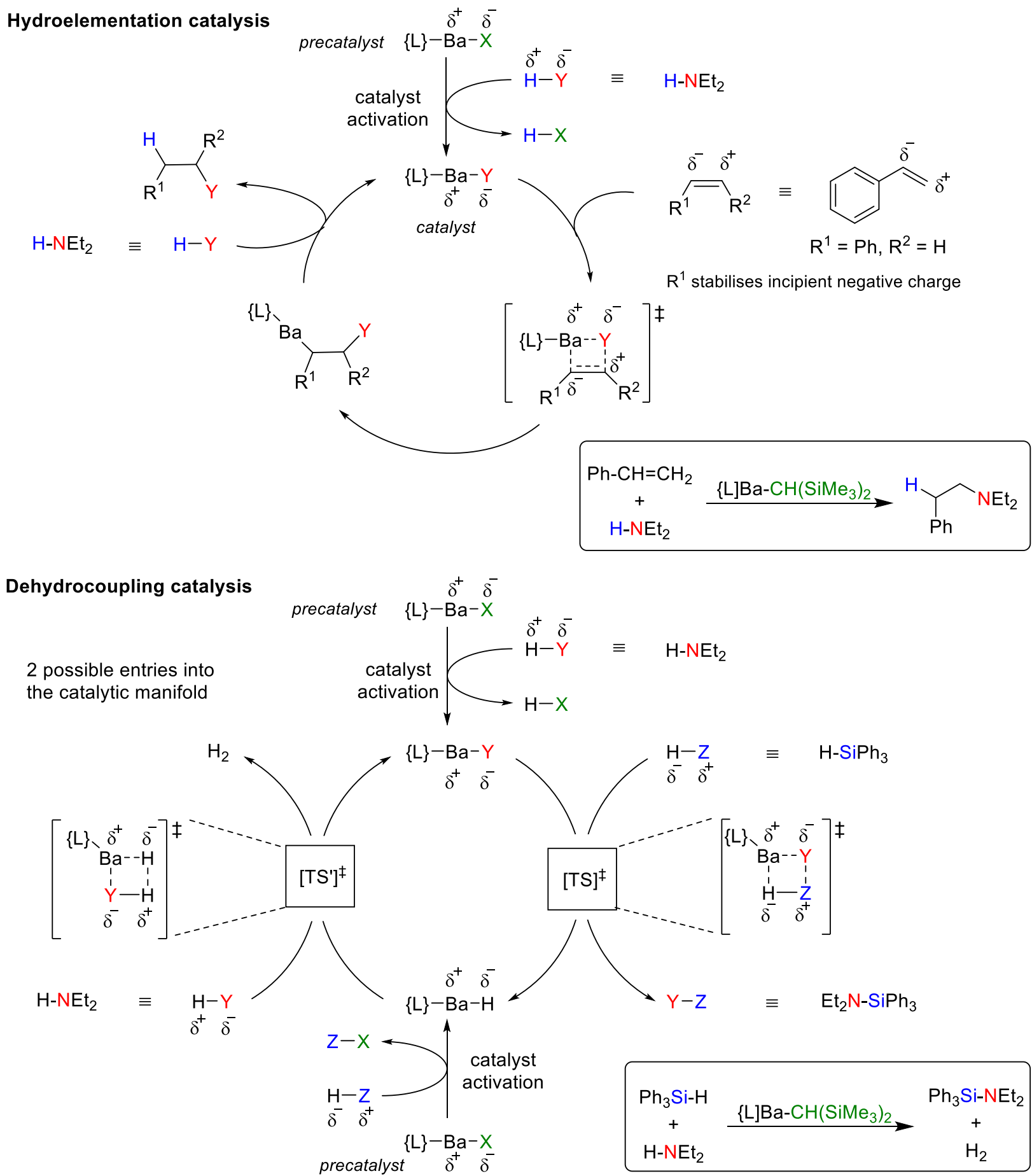

Figure 20. Catalysis mediated by barium and other large alkaline-earth metals; $\{\mathrm{L}\}=$ ligand. Top: standard mechanism for alkene hydroelementations, e.g. for the hydroamination of styrene with $\mathrm{HNEt}_{2}$. Bottom: typical mechanism for dehydrocouplings, illustrated with the coupling of $\mathrm{Ph}_{3} \mathrm{SiH}_{\mathrm{H}}$ and $\mathrm{HNEt}_{2}$. 


\section{Intramolecular hydroamination of aminoalkenes}

Alkaline-earth catalysed intramolecular hydroamination was first reported in 2005, for $\alpha, \omega$-aminoalkenes (the archetypal substrate being 1-amino-2,2-dimethyl-4-pentene) using $\left[\left\{\mathrm{BDI}^{\mathrm{DiPP}}\right\} \mathrm{CaN}\left(\mathrm{SiMe}_{3}\right)_{2} \cdot \mathrm{thf}\right]$ as a precatalyst, with the authors proposing a mechanism analogous to $4 \mathrm{f}$ element mediated cyclisations. ${ }^{[115]}$ The mechanism for this catalysed $\mathrm{C}-\mathrm{N}$ bond-creating process was later investigated for all $\beta$-diketiminates $\left[\left\{\mathrm{BDI}^{\mathrm{DiPP}}\right\} \mathrm{AeN}\left(\mathrm{SiMe}_{3}\right)_{2} \cdot(\text { thf })_{\mathrm{x}}\right](\mathrm{Ae}=\mathrm{Ca}, \mathrm{Sr}, \mathrm{Ba})$ and extended to the lighter $\left[\left\{\mathrm{BDI}^{\mathrm{DiPP}}\right\} \mathrm{Mg}^{n} \mathrm{Bu}\right]$. It was rationalised to proceed through aminolysis followed by the rate-determining intramolecular insertion of the polarised $\mathrm{C}=\mathrm{C}$ double bond into the newly formed Ae-N bond. ${ }^{[113]}$ Although the calcium catalyst was more active than the magnesium one, early results indicated that this trend would not continue down the group to the strontium and barium derivatives, though investigations were hampered due to the propensity of heavier species to undergo ligand redistribution in solution. ${ }^{[21]}$ Homoleptic Ba-amide or alkyl precatalysts were shown to be unsuitable for the intramolecular hydroamination of 1-amino-2,2-diphenyl-4-pentene, with the catalysts being limited to up to two turnovers before the precipitation of unknown insoluble products, a result attributed to the inability of barium centres to sufficiently polarise the $\mathrm{C}=\mathrm{C}$ bond to enable insertion. ${ }^{[16]}$ Later, a range of heteroleptic complex bearing various Ae complexes bearing phenolates or $\left\{\mathrm{BDI}^{\mathrm{DiPP}}\right\}^{-}$ancillary ligands and $\mathrm{N}\left(\mathrm{SiMe}_{3}\right)_{2}{ }^{-}$or $\mathrm{N}\left(\mathrm{SiMe}_{2} \mathrm{H}\right\}_{2}{ }^{-}$coligands were investigated to improve the understand reactivity patterns of the large alkaline earths in intramolecular hydroamination. ${ }^{[92]}$ Selected data highlighting the performance of barium precatalysts with respect to the state-of-the-art $\left[\left\{\mathrm{BDI}^{\mathrm{DiPP}}\right\} \mathrm{CaN}\left(\mathrm{SiMe}_{3}\right)_{2} \cdot\right.$ thf $]$ are assembled in Table 2 . The study showed activity in intramolecular hydroamination varied with $\mathrm{Ca}>\mathrm{Sr} \gg \mathrm{Ba}$, a trend opposite of that described for intermolecular hydroamination (and many other catalysed reactions, see below). These results were rationalised to be driven by entropic factors, proposing that the increasing ionic radii of $\mathrm{Ba}^{2+}$ relative to $\mathrm{Sr}^{2+}$ and $\mathrm{Ca}^{2+}$ may favour intermolecular over intramolecular reaction pathways, as the intramolecular cyclohydroaminations progressed through highly congested transition states. Intramolecular hydroamination has also recently been carried out by a range of tetrameric siloxide/amide barium clusters which involved a metal-ligand cooperative mechanism. ${ }^{[117]}$ Although the clusters required long reaction times (12-36 h, Table 2), these clusters did fully convert the substrate (2,2-diphenylpent-4-en-1-amine), and interestingly they overperformed their Sr analogues. The tert-butyl substituent in para position was found to substantially increase both solubility and reaction rates. Overall, barium precatalysts do not perform particularly well in intramolecular hydroamination catalysis compared to the lighter alkaline earths, and calcium systems should be favoured instead where high turnovers are sought. 
Table 2. Benchmark cyclohydroamination of 1 -amino-2,2- $R_{2}-4-$ pentene by various $A$ e catalysts $(R=M e, P h)$.

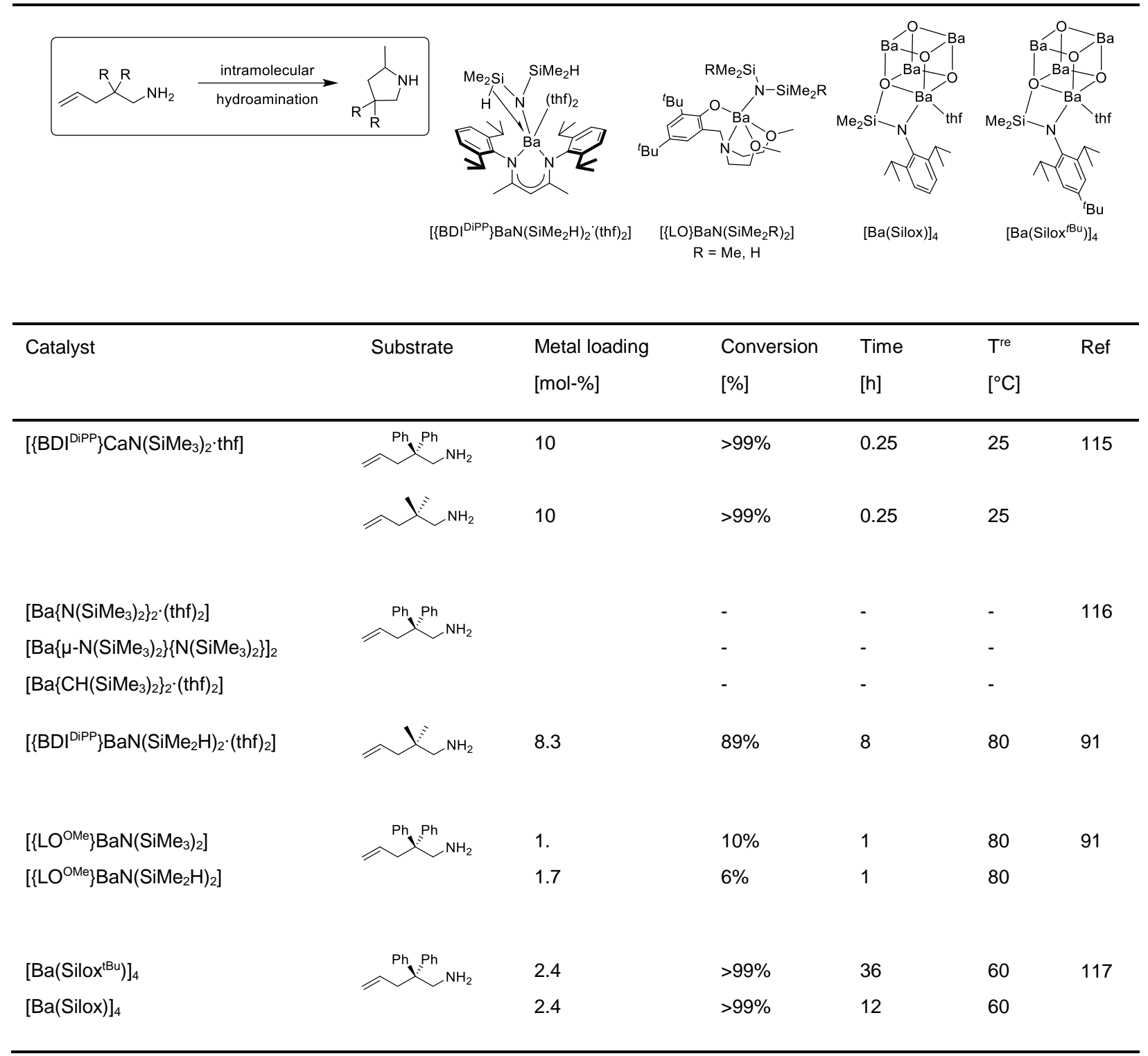

\section{Intermolecular hydroamination of activated alkenes}

Intermolecular hydroaminations are much more difficult to catalyse than their intramolecular version, and require more forcing conditions.The first investigation of intermolecular hydroamination was the computational study of a series $(\mathrm{Mg}, \mathrm{Ca}, \mathrm{Sr}, \mathrm{Ba})$ of simplified $\{\mathrm{BDI}\}$ models to generate free-energy profiles for the series of Ae metals. ${ }^{[18]}$ The results, based on the benchmark hydroaminations of styrene with benzylamine or pyrrolidine, indicated that the rate-limiting step transition state, assessed to be the insertion of the double bond into the Ae-N bond, was lower in energy for increasing size of the metal. However, in experimental results when the heavier alkaline earth amides $\left[\mathrm{Ae}\left\{\mu-\mathrm{N}\left(\mathrm{SiMe}_{3}\right)_{2}\right\}\left\{\mathrm{N}\left(\mathrm{SiMe}_{3}\right)_{2}\right\}\right]_{2}$ and alkyl $\left[\mathrm{Ae}\left\{\mathrm{CH}\left(\mathrm{SiMe}_{3}\right)_{2}\right\}_{2} \cdot(\text { thf })_{2}\right]$ compounds the hydroamination of styrene by piperidine, the strontium 
congeners outperformed the calcium and barium compounds. ${ }^{[19]}$ The low activity of the barium precatalysts was attributed to the more diffuse charge density of the $\mathrm{Ba}^{2+}$ resulting in a lower polarising effect on the alkene substrate. However, the barium catalytic systems $\left[\left\{\operatorname{ImAn}^{\mathrm{DiPP}}\right\} \mathrm{BaN}\left(\mathrm{SiMe}_{3}\right)_{2} \cdot(\operatorname{thf})_{2}\right]$, $\left[\left\{\mathrm{BDI}^{\mathrm{DiPP}}\right\} \mathrm{BaN}\left(\mathrm{SiMe}_{2} \mathrm{H}\right)_{2} \cdot(\mathrm{thf})_{2}\right]$ and $\left[\left\{\mathrm{LO}^{\mathrm{OMe}}\right\} \mathrm{BaN}\left(\mathrm{SiMe}_{3}\right)_{2}\right]$ are much more active in the hydroamination of styrene with pyrrolidine than their direct calcium and strontium analogues, reaching TOF values of 290 $\mathrm{h}^{-1} \cdot{ }^{[43,54]}$ Within each homologous family of precatalysts, the activity trend agreed to $\mathrm{Ca}<\mathrm{Sr}<\mathrm{Ba}$, independently of the identity of the supporting ancillary ligand. A later mechanistic study by DFT computations modelling the hydroamination of styrene with pyrrolidine catalysed by $\left[\left\{\operatorname{ImAn}^{\mathrm{DiPP}}\right\} \mathrm{AeN}\left(\mathrm{SiMe}_{3}\right)_{2} \cdot(\mathrm{thf})_{\mathrm{x}}\right](\mathrm{Ae}=\mathrm{Ca}, \mathrm{Sr}, \mathrm{Ba})$ showed the catalytically active species to be the [Ae]pyrrolide product of aminolysis. It also indicated that the observed activity trend was the outcome of stronger Ae- $\mathrm{N}_{\text {pyrrolide }}$ bonds and increased steric protection (restricting access to the metal) as metal size is decreasing. ${ }^{[120]}$ All Ae precatalysts for intermolecular hydroamination, and primarily barium ones amongst them, are regioselective, leading exclusively to the anti-Markovnikov addition product, via 2,1-insertion of the polarised $\mathrm{PhCH}_{2}=\mathrm{CH}_{2}$ double bond with a partial negative charge in $\alpha$ position to the aromatic ring. Although the reported barium precatalysts are amongst the most active systems to date for the intermolecular hydroamination of activated alkenes, they have been unable to proceed to the functionalisation of non-activated alkenes, e.g. 1-hexene or even norbornene. The amalgamated results of the intermolecular hydroamination results are tabulated in Table 3.

Table 3. Benchmark intermolecular hydroamination of styrene and amines catalysed by Ae precatalysts.

\begin{tabular}{|c|c|c|c|c|c|c|c|}
\hline Catalyst & Substrate & Product & $\begin{array}{l}\text { Metal loading } \\
\text { [mol-\%] }\end{array}$ & $\begin{array}{l}\text { Conversion } \\
{[\%]}\end{array}$ & $\begin{array}{l}\text { Time } \\
\text { [h] }\end{array}$ & $\begin{array}{l}\mathrm{T}^{\mathrm{re}} \\
{\left[{ }^{\circ} \mathrm{C}\right]}\end{array}$ & Ref \\
\hline$\left[\mathrm{Ca}\left\{\mu-\mathrm{N}\left(\mathrm{SiMe}_{3}\right)_{2}\right\}\left\{\mathrm{N}\left(\mathrm{SiMe}_{3}\right)_{2}\right\}\right]_{2}$ & & & 5 & $>99$ & 13 & 60 & 119 \\
\hline$\left[\mathrm{Sr}\left\{\mu-\mathrm{N}\left(\mathrm{SiMe}_{3}\right)_{2}\right\}\left\{\mathrm{N}\left(\mathrm{SiMe}_{3}\right)_{2}\right\}\right]_{2}$ & & & 5 & $>99$ & 5 & 60 & 119 \\
\hline$\left[\mathrm{Ba}\left\{\mu-\mathrm{N}\left(\mathrm{SiMe}_{3}\right)_{2}\right\}\left\{\mathrm{N}\left(\mathrm{SiMe}_{3}\right)_{2}\right\}\right]_{2}$ & & & 5 & $>99$ & 240 & 60 & 119 \\
\hline$\left[\left\{\mathrm{ImAn}^{\mathrm{DiPP}}\right\} \mathrm{CaN}\left(\mathrm{SiMe}_{3}\right)_{2} \cdot\right.$ thf $]$ & & & 2 & 34 & 18.5 & 60 & 43 \\
\hline$\left[\left\{\operatorname{ImAn} n^{\mathrm{DiPP}}\right\} \mathrm{SrN}\left(\mathrm{SiMe}_{3}\right)_{2} \cdot(\mathrm{thf})_{2}\right]$ & & & 2 & 71 & 18.5 & 60 & 43 \\
\hline$\left[\left\{\operatorname{ImAn}{ }^{\mathrm{DiPP}}\right\} \mathrm{BaN}\left(\mathrm{SiMe}_{3}\right)_{2} \cdot(\text { thf })_{2}\right]$ & & & 2 & 86 & 18.5 & 60 & 43 \\
\hline$\left[\left\{\mathrm{LO}^{\mathrm{OMe}}\right\} \mathrm{CaN}\left(\mathrm{SiMe}_{3}\right)_{2}\right]$ & & & 2 & 6 & 18.5 & 60 & 43 \\
\hline$\left[\left\{\mathrm{LO}^{\mathrm{OMe}}\right\} \mathrm{SrN}\left(\mathrm{SiMe}_{3}\right)_{2}\right]$ & & & 2 & 24 & 18.5 & 60 & 43 \\
\hline$\left[\left\{\mathrm{LO}^{\mathrm{OMe}}\right\} \mathrm{BaN}\left(\mathrm{SiMe}_{3}\right)_{2}\right]$ & & & 2 & 37 & 18.5 & 60 & 43 \\
\hline$\left[\left\{\mathrm{BDI}{ }^{\mathrm{DiPP}}\right\} \mathrm{BaN}\left(\mathrm{SiMe}_{2} \mathrm{H}\right) \cdot(\mathrm{thf})_{2}\right]$ & & & 2 & 64 & 2 & 60 & 43 \\
\hline
\end{tabular}




\section{Hydrophosphination}

The formation of C-P bonds in the catalysed hydrophosphination of alkenes and alkynes using the large alkaline earths was first reported using the amide $\left[\left\{\mathrm{BDI}^{\mathrm{DiPP}}\right\} \mathrm{CaN}\left(\mathrm{SiMe}_{3}\right)_{2} \cdot\right.$ thf $]$ for the hydrophosphination of activated alkenes such as styrene, diphenylethene, isoprene and 1,3-cyclohexadiene. ${ }^{[88]}$ Alkaline-earth catalysis is less developed here than for the related hydroamination reactions, and only intermolecular hydrophosphinations of activated alkenes have been investigated. However, of the alkaline earth (pre)catalysts, barium complexes have been not only significantly more effective than calcium or strontium, but are also amongst the most effective catalytic systems for this reaction. Within series of complexes supported by the same iminoanilide, ${ }^{[54]}$ phenolate, ${ }^{[43]}$ chiral benzamidinate ${ }^{[121]}$ or dianionic siloxideamide $^{[117]}$ ligands, the reaction rates for alkene hydrophosphination increase according to $\mathrm{Ca}<\mathrm{Sr}<\mathrm{Ba}$. The complexes $\left[\left\{\mathrm{ImAn}^{\text {crown }} \mathrm{BaN}\left(\mathrm{SiMe}_{2} \mathrm{H}\right)_{2}\right]\right.$ and $\left[\left\{\mathrm{Am}^{\text {crown }}\right\} \mathrm{BaN}\left(\mathrm{SiMe}_{2} \mathrm{H}\right)_{2}\right]$ bearing iminoanilide and amidinate ligands side-functionalised by aza -crown-ether tethers proved efficient. Even more recently, turnover frequencies as high as $23 \mathrm{~h}^{-1}$ were recorded at $25{ }^{\circ} \mathrm{C}$ for the bis(imino)carbazolate $\left[\left\{\mathrm{Carb}^{\mathrm{DiPP}}\right\} \mathrm{BaN}\left(\mathrm{SiMe}_{3}\right)_{2}\right]$, making it the most effective precatalyts for this reaction to date (Table 4$)$. Barium-mediated intermolecular alkene hydrophosphination proceeds with complete anti-Markovnikov regioselectivity. The proposed catalytic cycle for is similar to that of hydroamination, involving protonolysis to give a catalytically active Ba-phosphide followed by insertion of the alkene and protonolysis to regenerate the Ba-phosphide. Interestingly, due to the low solubility of homoleptic bis(phosphide) compounds in aliphatic and aromatic hydrocarbon solvents, hydrophosphination activity using barium (and Ae) precatalysts is higher using heteroleptic complexes supported by a solubilising ancillary ligand. The hydrophosphination of carbodiimides using the Ae-amides $\left[\mathrm{Ae}\left\{\mathrm{N}\left(\mathrm{SiMe}_{3}\right)_{2}\right\}_{2} \cdot(\mathrm{thf})_{2}\right], \quad[\mathrm{Ca}\{\mu-$ $\left.\left.\mathrm{N}\left(\mathrm{SiMe}_{3}\right)_{2}\right\}\left\{\mathrm{N}\left(\mathrm{SiMe}_{3}\right)_{2}\right\}\right]_{2}$ and the heteroleptic $\left[\left\{\mathrm{BDI}^{\mathrm{DiPP}}\right\} \mathrm{CaN}\left(\mathrm{SiMe}_{3}\right)_{2} \cdot\right.$ thf $]$ have also been reported. ${ }^{[43]}$ Unlike the earlier hydrophosphination of alkenes, the study found that the homoleptic amides performed better than the heteroleptic complexes, and that catalytic activity increased with metal size $(\mathrm{Ca}<\mathrm{Sr}<\mathrm{Ba})$ with TOF values reaching $250 \mathrm{~h}^{-1}$ for $\left[\mathrm{Ba}\left\{\mathrm{N}\left(\mathrm{SiMe}_{3}\right)_{2}\right\}_{2} \cdot(\mathrm{thf})_{2}\right]$. It must be noted that the barium-catalysed (and Ae) intermolecular hydrophosphination of unsaturated $\mathrm{C}-\mathrm{C}$ bonds is for the time being restricted to activated alkenes such as styrenes and conjugated dienes. This is also true for intermolecular hydroamination reactions. The reason behind this limitation is that in in the course of the often rate-limiting $\sigma$-insertive, stabilising aromatic or allylic groups are necessary to assuage the negative charge that develops in the transition state on the carbon atom of the substrate in $\alpha$ position to the metal (see Scheme 20, top). 
Table 4. Benchmark styrene and cardodiimine hydrophosphinations catalysed by selected barium and Ae complexes.

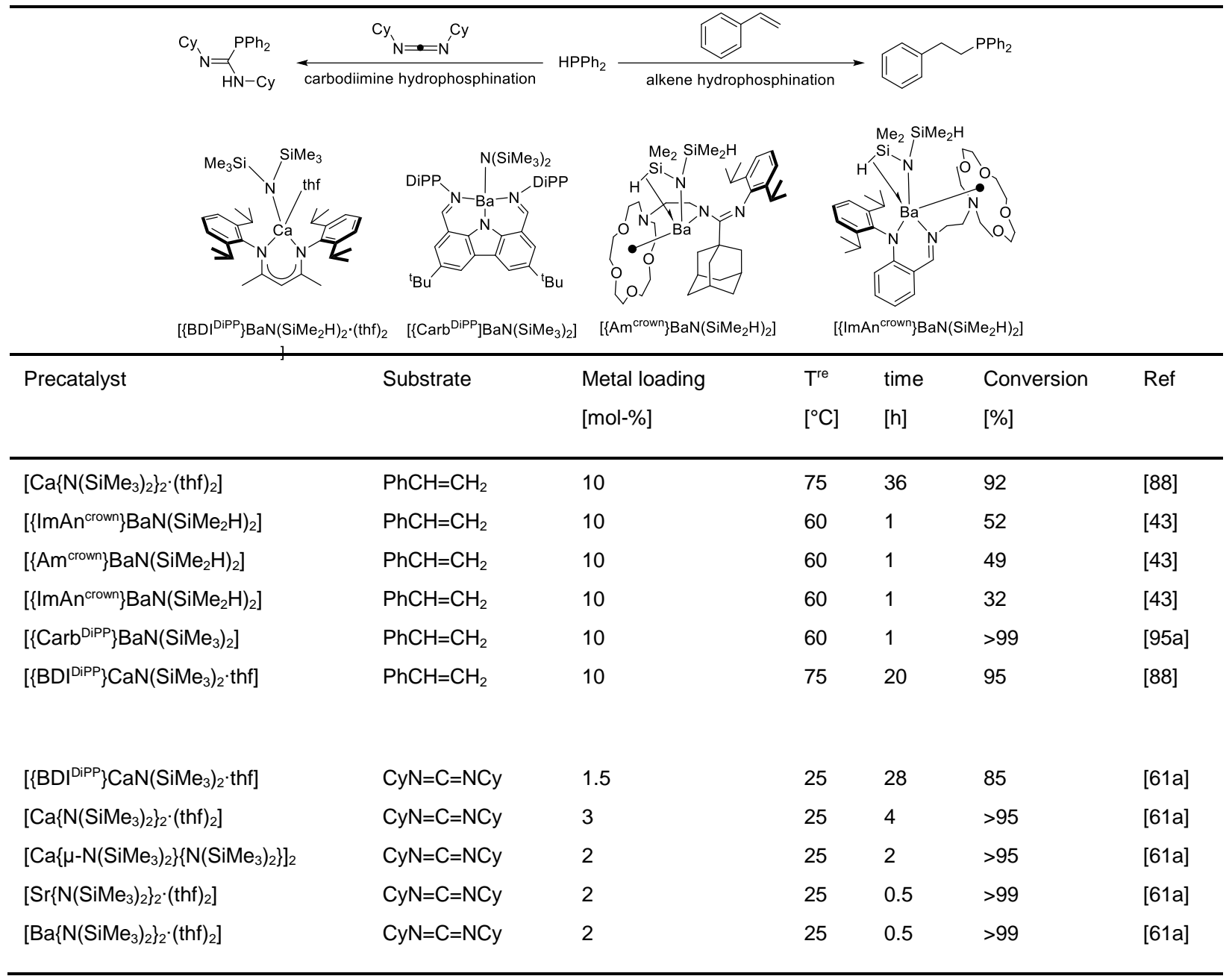

\section{Hydrogenation}

Ae-mediated hydrogenation is one of the topics that has seen the most developments in the last decade, ever since Harder's report of the hydrogenation of diphenylethene by calcium hydride or alkyl complexes, showing that efficient alkene activation can occur using only electrostatic interactions and metal-induced polarisation. ${ }^{[5,122]}$ Catalysis using molecular barium hydrides has been achieved using the aforementioned superbulky complex $\left[\left\{\mathrm{Cp}^{\mathrm{Ar}}\right\} \mathrm{Ba}(\mu-\mathrm{H}) . \text { dabco }\right]_{2}{ }^{[55]}$ This hydride species was capable of fully hydrogenating (>97\% conversion) a range of activated and non-activated alkenes including trimethylsilylethane, 1-hexene, diphenylethene, 2-methylstyrene, 1-phenylcyclohexene and 1,1,2,2-tetraphenylethene under reasonably mild conditions (Table 5). The simple barium amide $\left[\mathrm{Ba}\left\{\mu-\mathrm{N}\left(\mathrm{SiMe}_{3}\right)_{2}\right\}\left\{\mathrm{N}\left(\mathrm{SiMe}_{3}\right)_{2}\right\}\right]_{2}$ (and its $\mathrm{Ca}$ and $\mathrm{Sr}$ congeners) have also been shown to be suitable precatalysts for a range of alkene hydrogenations, with the activity increasing in the series $\mathrm{Ca}<\mathrm{Sr}<\mathrm{Ba}$ (Table 5). ${ }^{[63]}$ The proposed catalytic cycle involves the unexpected deprotonation of $\mathrm{H}_{2}$ by the amide (the $p \mathrm{~K}_{\mathrm{a}}$ of 49 for $\mathrm{H}_{2}$ being much higher than the 25.8 value for $\left.\mathrm{HN}\left(\mathrm{SiMe}_{3}\right)_{2}\right)$ followed by assumed aggregation to barium clusters, the presumed active species. ${ }^{[3]}$ 
Table 5. Illustrative data for barium-catalysed hydrogenation reactions.

\begin{tabular}{|c|c|c|c|c|c|c|c|c|}
\hline Precatalyst & $\begin{array}{l}\text { Metal } \\
\text { [mol-\%] }\end{array}$ & Substrate & Product & $\begin{array}{l}\text { H-source } \\
\text { [pressure/eq)] }\end{array}$ & $\begin{array}{l}\mathrm{T} \\
{\left[{ }^{\circ} \mathrm{C}\right]}\end{array}$ & $\begin{array}{l}\text { time } \\
{[\mathrm{h}]}\end{array}$ & $\begin{array}{l}\text { Conversion } \\
{[\%]}\end{array}$ & Ref \\
\hline \multirow[t]{4}{*}[\{\mathrm{Cp}^{\mathrm{Ar}}\}\mathrm{Ba}(\mu-\mathrm{H})\cdot\mathrm{dabco}]{$_{2}$} & 5 & $\mathrm{SiMe}_{3}$ & $\mathrm{SiMe}_{3}$ & $\mathrm{H}_{2}$ (6.1 bar) & 30 & 6 & 99 & [55] \\
\hline & 5 & & & $\mathrm{H}_{2}$ (6.1 bar) & 30 & 1.5 & 99 & [55] \\
\hline & 5 & & & $\mathrm{H}_{2}(6.1$ bar $)$ & 30 & 8 & $91^{[\mathrm{al}}$ & [55] \\
\hline & 5 & & & $\mathrm{H}_{2}$ (6.1 bar $)$ & 30 & 24 & 5 & [55] \\
\hline \multirow[t]{5}{*}[\mathrm{Ba}\{\mu-\mathrm{N}(\mathrm{SiMe}_{3})_{2}\}\{\mathrm{N}(\mathrm{SiMe}_{3})_{2}\}]{$_{2}$} & 10 & & & $\mathrm{H}_{2}(6$ bar $)$ & 80 & 0.25 & 99 & [33] \\
\hline & 10 & & & $\mathrm{H}_{2}$ (6 bar) & 25 & 15 & 99 & [33] \\
\hline & 1 & & & $\mathrm{H}_{2}(6$ bar $)$ & 80 & 24 & 99 & [33] \\
\hline & 10 & & & $\mathrm{H}_{2}(6$ bar $)$ & 120 & 0.75 & 99 & [33] \\
\hline & 10 & & & $\mathrm{H}_{2}(6$ bar $)$ & 120 & 24 & $1: 58: 42^{[b]}$ & [33] \\
\hline \multirow[t]{6}{*}[\mathrm{Ba}\{\mathrm{N}(\mathrm{Si}^{i}\mathrm{Pr}_{3})_{2}\}_{2}]{} & 10 & $e_{3}$ & & $\mathrm{H}_{2}(6$ bar $)$ & 60 & 2 & 99 & {$[123]$} \\
\hline & 1 & & & $\mathrm{H}_{2}$ (6 bar) & 120 & 0.5 & 99 & [123] \\
\hline & 10 & & & $\mathrm{H}_{2}(6$ bar $)$ & 60 & 6 & 99 & [123] \\
\hline & 1 & & & $\mathrm{H}_{2}(6$ bar $)$ & 120 & 4 & 99 & [123] \\
\hline & 10 & & & $\mathrm{H}_{2}$ (12 bar) & 120 & 2 & 99 & [123] \\
\hline & 10 & & & $\mathrm{H}_{2}$ (12 bar) & 120 & 72 & 18 & [123] \\
\hline \multirow[t]{3}{*}[\mathrm{Ba}\{\mu-\mathrm{N}(\mathrm{SiMe}_{3})_{2}\}\{\mathrm{N}(\mathrm{SiMe}_{3})_{2}\}]{$_{2}$} & 5 & & $\mathrm{Me}_{3}$ & 1,4-CHD (1.5) & 60 & 4.25 & 99 & [124] \\
\hline & 5 & & & 1,4-CHD (1.5) & 60 & 1.5 & 99 & [124] \\
\hline & 5 & & & 1,4-CHD (5) & 120 & 16 & 99 & [124] \\
\hline
\end{tabular}

[a] 9\% 2-diphenyl-2-methylpentane formation. [b] Starting material:isomerised alkene:alkane,

The energy released by aggregation is proposed to be the driving force behind the reaction. The Ba-amide precatalyst has the advantage over the barium-hydride cluster $\left[\mathrm{Ba}_{7} \mathrm{H}_{7}\left\{\mathrm{~N}\left(\mathrm{SiMe}_{3}\right)_{2}\right\}_{7} \cdot\left(\mathrm{C}_{6} \mathrm{H}_{6}\right)_{2}\right]$ of a much simpler synthesis, even if the catalytic results are slightly poorer. More recently, the bulkier amido precursors $\left[\mathrm{Ba}\left\{\mathrm{N}\left(\mathrm{Si}^{i} \mathrm{Pr}_{3}\right)(\mathrm{DiPP})\right\}_{2}\right]$ and $\left[\mathrm{Ba}\left\{\mathrm{N}\left(\mathrm{Si}^{i} \mathrm{Pr}_{3}\right)_{2}\right\}_{2}\right]$ were used to generate in situ '(amide)BaH' 
clusters for the hydrogenation of alkenes. ${ }^{[123]}$ The precatalyst $\left[\mathrm{Ba}\left\{\mathrm{N}\left(\mathrm{Si}^{i} \mathrm{Pr}_{3}\right)_{2}\right\}_{2}\right]$ was found to be the most active, a result attributed to its increased steric bulk favouring smaller, more active agglomerates in solution. It was capable of reducing demanding substrates such as ${ }^{t} \mathrm{BuCH}=\mathrm{CH}_{2}, 1,1,2,2$-tetraphenylethene and norbornene, and even managed the partial hydrogenation of benzene. However, the hydrogenation of substrates sensitive to oligomerisation did prove problematic, such as for $\alpha$-methylstyrene, which resulted in considerable amounts of a dimerised side-product. Although all of the previous examples require the activation of dihydrogen to provide the hydride, transfer hydrogenation has also been reported using $[\operatorname{Ae}\{\mu$ $\left.\left.\mathrm{N}\left(\mathrm{SiMe}_{3}\right)_{2}\right\}\left\{\mathrm{N}\left(\mathrm{SiMe}_{3}\right)_{2}\right\}\right]_{2}$ with 1,4-cyclohexadiene (1,4-CHD) as the hydride source. ${ }^{[124]}$ The formation of ethylbenzene from styrene and 1.5 equivalent of 1,4-CHD occurred with $>99 \%$ conversion after 45 min at $60{ }^{\circ} \mathrm{C}$ using $\left[\left[\left(\mathrm{Me}{ }_{3} \mathrm{Si}\right)_{2} \mathrm{~N}-\mathrm{Ba}\left\{\mu-\mathrm{N}\left(\mathrm{SiMe}_{3}\right)_{2}\right\}\right]_{2}\right]$ (Table 5). The study showed the same reactivity trend $\mathrm{Ca}<$ $\mathrm{Sr}<\mathrm{Ba}$ as for most other catalysed reactions. The study also showed that with the precatalyst $\left[\left\{\mathrm{BDI}^{\mathrm{DiPP}}\right\} \mathrm{CaN}\left(\mathrm{SiMe}_{3}\right)_{2}\right]$, after 24 hours but with otherwise identical conditions, only traces of ethylbenzene were formed, along with benzene, $\mathrm{H}_{2}$ and 1,3-CHD from the isomerisation of 1,4-CHD.

The hydrogenation of imines has also been carried out using $\left[\mathrm{Ba}\left\{\mathrm{N}\left(\mathrm{SiMe}_{3}\right)_{2}\right\}_{2} \cdot(\text { thf })_{2}\right]$, via the metalinduced polarisation of $\mathrm{H}_{2}$ (Figure 21). ${ }^{[62]}$ Although the study primarily investigated the effect of changing the imine substrate, the precatalyst used was also investigated. It was found that $\left[\mathrm{Ba}\left\{\mathrm{N}\left(\mathrm{SiMe}_{3}\right)_{2}\right\}_{2} \cdot(\operatorname{thf})_{2}\right]$ was the most active amongst a group that included all alkali-amides ( $\mathrm{Li}, \mathrm{Na}$ and $\mathrm{K})$ and the thf-free $[\mathrm{Ae}\{\mu$ $\left.\left.\mathrm{N}\left(\mathrm{SiMe}_{3}\right)_{2}\right\}\left\{\mathrm{N}\left(\mathrm{SiMe}_{3}\right)_{2}\right\}\right]_{2}(\mathrm{Ae}=\mathrm{Ca}, \mathrm{Sr})$. The efficacy of the thf-free barium amide was not assessed. At 80 ${ }^{\circ} \mathrm{C}$ in benzene, the hydrogenation of $N$-tert-butyl-1-phenylmethanimine was complete after 45 min, while at $120^{\circ} \mathrm{C}$ in hexane conversion was complete after less than $15 \mathrm{~min}$.

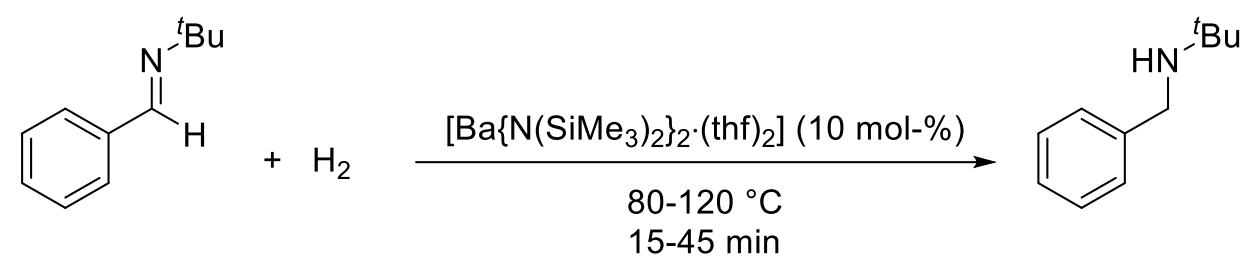

Figure 21. Imine hydrogenation catalysed by $\left[\mathrm{Ba}\left\{\mathrm{N}\left(\mathrm{SiMe}_{3}\right)_{2}\right\}_{2} \cdot(\mathrm{thf})_{2}\right]{ }^{[62]}$

\section{Amine-hydrosilane dehydrocoupling}

The catalysed synthesis of silazanes via silane-amine dehydrocoupling, yielding Si-N bond formation through the coupling of a hydrosilane and an amine with concomitant release of $\mathrm{H}_{2}$, is a desirable synthetic method due to its high atom efficiency and its avoidance of corrosive coproducts; the traditional route to silazanes between an amine and chlorosilane produces one equivalent of $\mathrm{HCl}$. The first use of alkaline-earth metals catalysing the production of silazanes was reported using a tris(oxazolinyl)boratomagnesium amide in 2011, with the first heavier-alkaline earth catalysts being used in 2013 and showing a strong increase in 
rate with increasing metal size. ${ }^{[125]}$ The use of the barium precatalysts $\left[\mathrm{Ba}\left\{\mathrm{E}\left(\mathrm{SiMe}_{3}\right)_{2}\right\}_{2} \cdot(\text { thf })_{\mathrm{x}}\right]$ and $\left[\left\{\operatorname{ImAn}^{\mathrm{DiPP}}\right\} \mathrm{BaE}\left(\mathrm{SiMe}_{3}\right)_{2} \cdot(\text { thf })_{2}\right]$ (with $\mathrm{E}=\mathrm{N}$ or $\mathrm{CH}$ ) for $\mathrm{N}-\mathrm{H} / \mathrm{H}-\mathrm{Si}$ dehydrocoupling was reported for the chemoselective formation of broad range of primary and secondary aryl and alkyl amines with mono, di and triphenylsilanes; it showed a significant increase in activity over the previously reported $\mathrm{Mg}, \mathrm{Ca}$ and Sr catalysts. ${ }^{[64,126]}$ Substrate scope was extended to $\alpha, \omega$-diamines and $\alpha, \omega$-dihydrosilanes. The bariummediated reactions were both very fast and chemoselective, affording the formation of clean products. A combination of experimental and DFT investigations showed that the catalysis proceeds by amine coordination followed by nucleophilic attack of the metal-bound amide onto the incoming silane, resulting in a transient silicate intermediate. Hydrogen transfer from the silicate to the metal to generate a hydride species and elimination of the silazane product is the rate limiting step. Protonolysis of another amine then generates $\mathrm{H}_{2}$ and the amide (the proposed catalytically active species), thus completing the catalytic manifold. This stepwise mechanism, supported by DFT and kinetic analysis, is more sophisticated than the prototypical version depicted in Figure 20. Comparative selected results highlighting the increase of activity of various Ba precatalysts are collected in Table 6.

Table 6. Comparative data for the Ae-catalysed dehydrocoupling of amines and hydrosilanes. ${ }^{[64]}$

\begin{tabular}{|c|c|c|c|c|c|c|}
\hline & $\mathrm{NH}+$ & $\mathrm{H}-\mathrm{SiPh}_{3}$ & $\rightarrow \mathrm{R}^{\mathrm{R}_{1}}{ }^{\prime} \mathrm{N}-\mathrm{Si}$ & & & \\
\hline Precatalyst & Substrate & Silane & $\begin{array}{l}\text { Metal loading } \\
(\%)\end{array}$ & $\begin{array}{l}\mathrm{T}^{\mathrm{re}} \\
{\left[{ }^{\circ} \mathrm{C}\right]}\end{array}$ & $\begin{array}{l}\mathrm{t} \\
{[\mathrm{h}]}\end{array}$ & $\begin{array}{l}\text { Conv } \\
{[\%]}\end{array}$ \\
\hline$\left[\mathrm{Mg}\left\{\mathrm{N}\left(\mathrm{SiMe}_{3}\right)_{2}\right\}_{2}\right]$ & & \multirow{9}{*}{$\mathrm{H}-\mathrm{SiPh}_{3}$} & 0.25 & 25 & 15 & 2 \\
\hline$\left[\mathrm{Ca}\left\{\mathrm{N}\left(\mathrm{SiMe}_{3}\right)_{2}\right\}_{2} \cdot(\text { thf })_{2}\right]$ & & & 0.25 & 25 & 15 & 72 \\
\hline$\left[\mathrm{Sr}\left\{\mathrm{N}\left(\mathrm{SiMe}_{3}\right)_{2}\right\}_{2} \cdot(\text { thf })_{2}\right]$ & & & 0.25 & 25 & 15 & 99 \\
\hline$\left[\mathrm{Ba}\left\{\mathrm{N}\left(\mathrm{SiMe}_{3}\right)_{2}\right\}_{2} \cdot(\text { thf })_{2}\right]$ & & & 0.25 & 25 & 0.08 & 53 \\
\hline$\left[\mathrm{Ba}\left\{\mathrm{N}\left(\mathrm{SiMe}_{3}\right)_{2}\right\}_{2} \cdot(\text { thf })_{2}\right]$ & & & 0.25 & 25 & 0.25 & 99 \\
\hline$\left[\mathrm{Ba}\left\{\mathrm{CH}\left(\mathrm{SiMe}_{3}\right)_{2}\right\}_{2} \cdot(\text { thf })_{3}\right]$ & & & 0.25 & 25 & 0.08 & 75 \\
\hline$\left[\mathrm{Ba}\left\{\mathrm{CH}\left(\mathrm{SiMe}_{3}\right)_{2}\right\}_{2} \cdot(\text { thf })_{3}\right]$ & & & 0.25 & 25 & 0.25 & 99 \\
\hline$\left[\left(\operatorname{lmAn}{ }^{\mathrm{DiPP}}\right\} \mathrm{BaN}\left(\mathrm{SiMe}_{3}\right)_{2} \cdot(\mathrm{thf})_{2}\right]$ & & & 0.25 & 25 & 2 & 94 \\
\hline$\left[\left\{\operatorname{ImAn}{ }^{\mathrm{DiPP}}\right\} \mathrm{BaCH}\left(\mathrm{SiMe}_{3}\right)_{2} \cdot(\text { thf })_{2}\right]$ & & & 0.25 & 25 & 0.25 & 52 \\
\hline$\left[\mathrm{Ca}\left\{\mathrm{CH}\left(\mathrm{SiMe}_{3}\right)_{2}\right\}_{2} \cdot(\mathrm{thf})_{3}\right]$ & \multirow[t]{3}{*}{$>\mathrm{NH}_{2}$} & \multirow[t]{3}{*}{$\mathrm{H}-\mathrm{SiPh}_{3}$} & 5 & 60 & 2 & $9^{a}$ \\
\hline$\left[\mathrm{Sr}\left\{\mathrm{CH}\left(\mathrm{SiMe}_{3}\right)_{2}\right\}_{2} \cdot(\mathrm{thf})_{3}\right]$ & & & 5 & 60 & 2 & $82^{\mathrm{a}}$ \\
\hline$\left[\mathrm{Ba}\left\{\mathrm{CH}\left(\mathrm{SiMe}_{3}\right)_{2}\right\}_{2} \cdot(\text { thf })_{3}\right]$ & & & 5 & 60 & 2 & $95^{\mathrm{a}}$ \\
\hline
\end{tabular}

[a] only the monocoupled product observed.

The alkyl compound $\left[\mathrm{Ba}\left\{\mathrm{CH}\left(\mathrm{SiMe}_{3}\right)_{2}\right\} \cdot(\text { thf })_{2}\right]$ was the most active precatalyst, although other homoleptic and heteroleptic barium compounds were also found to catalyse the reaction extremely well. Later on, 
barium catalysis was implemented in polycondensations for the synthesis of relatively high molecular weight polycarbosilazanes ${ }^{[22]}$, including ferrocene-containing polymers. ${ }^{[127]}$ A stepwise approach via alternating introduction of -(NR)- and -( $\left.\mathrm{SiR}_{2}{ }_{2}\right)$ - motifs was also attempted, but failed due to the propensity of -(RN-SiR' $\left.{ }_{2}\right)$ - units to generate stable four-member cyclo-disilazanes. ${ }^{[128]}$

\section{Other dehydrocoupling reactions}

Dehydrocoupling with barium precatalysts has also used for the formation of borasiloxanes $\mathrm{R}_{2} \mathrm{~B}-\mathrm{O}-\mathrm{SiR}_{3}$, by coupling of borinic acids $\mathrm{R}_{2} \mathrm{BOH}$ with hydrosilanes HSiR ' ${ }_{3}$ and release of dihydrogen (Figure 22a). ${ }^{25,85]}$ The three barium boryloxides $\left[\mathrm{Ba}\left\{\mathrm{OB}\left(\mathrm{CH}\left(\mathrm{SiMe}_{3}\right)_{2}\right)_{2}\right\}_{2}\right],\left[\mathrm{Ba}\left\{\mathrm{OB}\left(\mathrm{CH}\left(\mathrm{SiMe}_{3}\right)_{2}\right)_{2}\right\}_{2}\right.$.tol] and $\left[\mathrm{Ba}\left\{\mu_{2^{-}}\right.\right.$ $\left.\left.\mathrm{N}\left(\mathrm{SiMe}_{3}\right)_{2}\right\}\left\{\mathrm{OB}\left(\mathrm{CH}\left(\mathrm{SiMe}_{3}\right)_{2}\right)_{2}\right\}\right]_{2}$, as well as the amides $\left[\mathrm{Ba}\left\{\mu-\mathrm{N}\left(\mathrm{SiMe}_{3}\right)_{2}\right\}\left\{\mathrm{N}\left(\mathrm{SiMe}_{3}\right)_{2}\right\}\right]_{2}$ and $\left[\mathrm{Ba}\left\{\mathrm{N}\left(\mathrm{SiMe}_{3}\right)_{2}\right\}_{2} \cdot(\text { thf })_{2}\right]$, catalyse the reaction between $\mathrm{PhSiH}_{3}$ and $\left\{\left(\mathrm{Me}_{3} \mathrm{Si}\right)_{2} \mathrm{CH}\right\}_{2} \mathrm{BOH}$. The homoleptic amides were found to be both the most active and the easiest to access. The reaction rates increase substantially with metal size: $\mathrm{Ca}<\mathrm{Sr}<\mathrm{Ba}$. The substrate scope for hydrosilanes included aryl, alkyl and alkoxy hydrosilanes, with decreasing activity in that order. Substrate was more limited concerning the borinic acids, with only the alkyl borinic acid $\left\{\left(\mathrm{Me}_{3} \mathrm{Si}\right)_{2} \mathrm{CH}\right\}_{2} \mathrm{BOH}$ fully converting at $60{ }^{\circ} \mathrm{C}$, while aryl borinic acid required more forcing conditions to only reach poor to moderate conversions. The substrate scope could not be extended to less bulky borinic acids, due to their tendency to undergo self-condensation to form $\mathrm{R}_{2} \mathrm{~B}-\mathrm{O}-\mathrm{BR}_{2}$ species and noxious water. Kinetic analysis was performed, and the mechanism was delineated using DFT calculations for the catalyst $\left[\mathrm{Ba}\left\{\mathrm{OB}\left(\mathrm{CH}\left(\mathrm{SiMe}_{3}\right)_{2}\right)_{2}\right\}_{2}\right]$. In agreement with the kinetic data accumulated for both monomeric and dimeric precatalysts, the catalytic manifold was proposed to progress through a dinuclear transition state.

In a similar study, it was found that the barium siloxides $\left[\left[\mathrm{Ba}_{2}\left\{\mu_{2}-\mathrm{OSi}\left(\mathrm{SiMe}_{3}\right)_{3}\right\}_{3}\left\{\mathrm{OSi}\left(\mathrm{SiMe}_{3}\right)_{3}\right\}\right]\right.$ and $\left[\mathrm{Ba}\left\{\mu-\mathrm{OSi}\left(\mathrm{SiMe}_{3}\right)_{3}\right\}\left\{\mathrm{N}\left(\mathrm{SiMe}_{3}\right)_{2}\right\}\right]_{2}$, as well as the amide $\left[\mathrm{Ba}\left\{\mathrm{N}\left(\mathrm{SiMe}_{3}\right)_{2}\right\}_{2} \cdot(\text { thf })_{2}\right]$, are active precatalysts for the dehydrocoupling of hydrosilanes $\mathrm{R}_{3} \mathrm{SiH}$ and silanols $\mathrm{R}_{3}{ }_{3} \mathrm{SiOH}$, allowing for the formation of asymmetric siloxanes $\mathrm{R}_{3} \mathrm{Si}-\mathrm{O}-\mathrm{SiR}_{3}$ in controlled and chemoselective way (Figure 22b). ${ }^{[84]}$ Substrate scope was confined to bulky silanols. Preliminary kinetic analysis highlighted an unusual catalytic manifold, and catalyst inhibition by the silanol substrate. Yet, the presented data were consistent with a mechanism involving nucleophilic attack of the Ba-bound $\mathrm{O}_{\text {siloxide }}$ atom onto the incoming hydrosilane, thus generating a pentavalent hydrosilicate, in a scenario reminiscent of that established for the Ba-catalysed formation of silazanes and borasiloxanes.

Barium-catalysed dehydrocoupling has also been used to obtain silylethers from hydrosilanes and alcohols. ${ }^{[127]}$ The precatalysts $\left[\mathrm{Ae}\left\{\mathrm{N}\left(\mathrm{SiMe}_{3}\right)_{2}\right\}_{2} \cdot(\text { thf })_{2}\right]$ and $\left[\mathrm{Ae}\left\{\mathrm{CH}\left(\mathrm{SiMe}_{3}\right)_{2}\right\}_{2} \cdot(\text { thf })_{2}\right]$ were screened for Ae $=\mathrm{Ca}, \mathrm{Sr}, \mathrm{Ba}$, with the barium precatalysts displaying the highest activity. Unlike for silazane dehydrocoupling, the barium alkyl did not give a discernible improvement over the amide precatalyst. The 
dehydrocoupling between $\mathrm{PhSiH}_{3}$ or $\mathrm{Ph}_{2} \mathrm{SiH}_{2}$ worked well with a range of primary, secondary and tertiary alcohols. When using the hydrosilane $\mathrm{PhSiH}_{3}$, selectivity between the products $\left((\mathrm{RO}) \mathrm{SiPhH}_{2},(\mathrm{RO})_{2} \mathrm{SiPhH}\right.$ or $(\mathrm{RO})_{3} \mathrm{SiPh}$ ) could be achieved by simply changing the reaction stoichiometry and/or precatalyst, although long reaction times were needed for good conversions of $(\mathrm{RO})_{3} \mathrm{SiPh}$. The products of monocoupling (RO) $\mathrm{SiH}_{2} \mathrm{Ph}$ could be detected spectroscopically when using $\mathrm{PhSiH}_{3}$, however they could not be isolated.

(a)

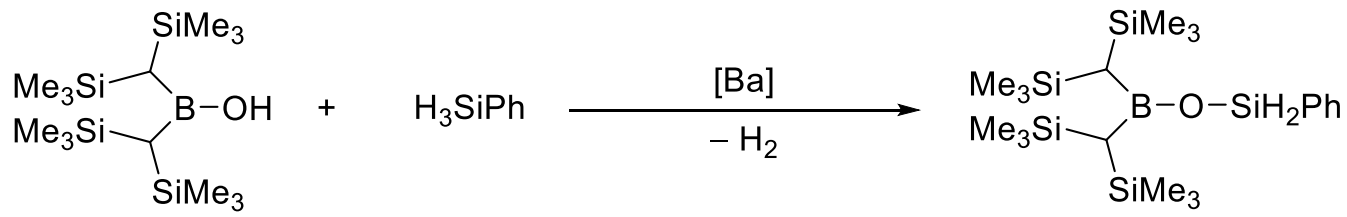

(b)

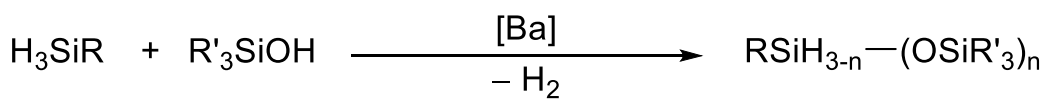

(c)

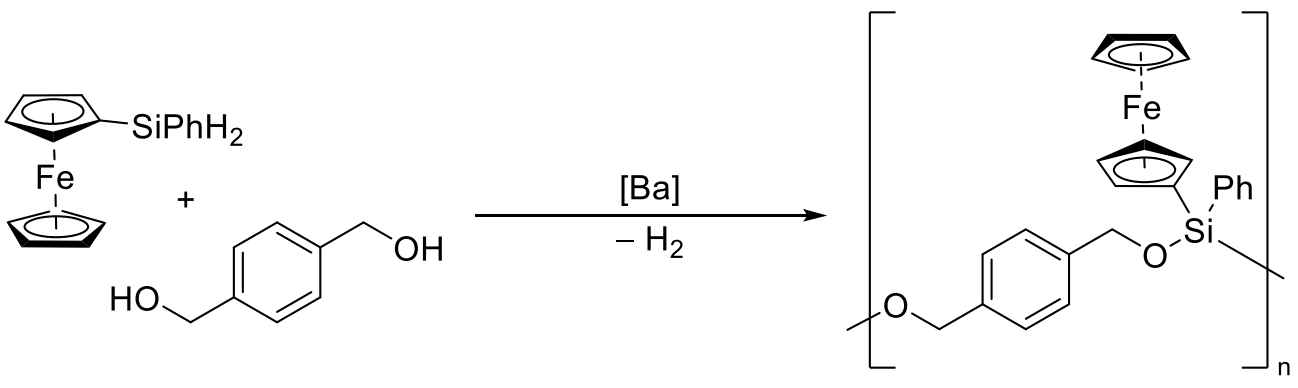

(d)

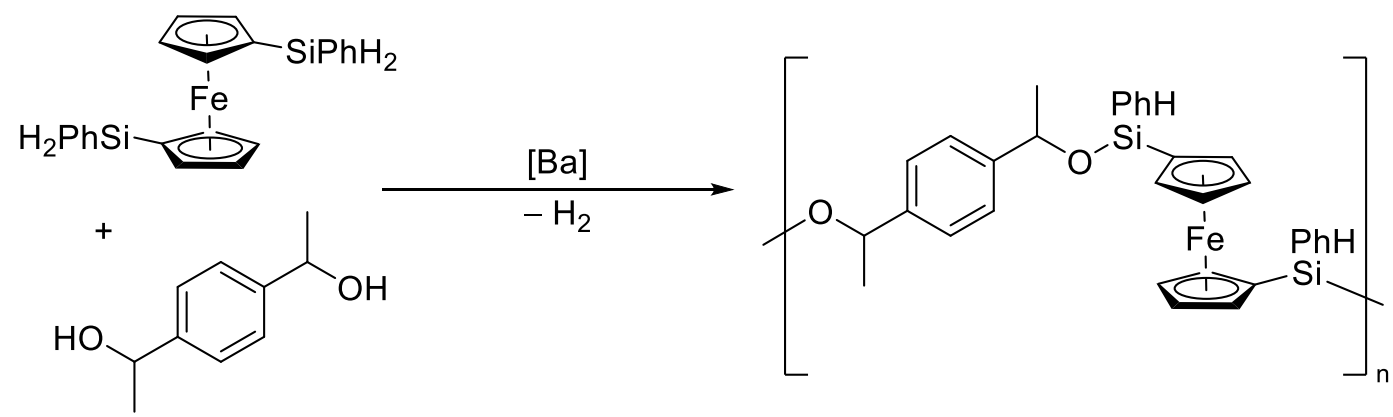

Figure 22. Barium-mediated dehydrocoupling catalysis (a) Borinic acids and hydrosilanes towards borasiloxanes. ${ }^{[25,85]}$ (b) Silanols and hydrosilanes towards asymmetric siloxanes. ${ }^{[8]}$ (c) Ferrocenecontaining polysilylethers (pendant). ${ }^{[127]}$ (d) Ferrocene-containing polysilylethers (main chain). ${ }^{[127]}$

The synthesis of secondary silylethers $(\mathrm{RO})_{2} \mathrm{SiHPh}$ were only selective when using bulky alcohols such as tert-butanol. With less bulky alcohols such as isopropanol, the reactions returned mixtures of the dicoupled $(\mathrm{RO})_{2} \mathrm{SiPhH}$ and tricoupled $(\mathrm{RO})_{3} \mathrm{SiPh}$ products. Ferrocenyl silylethers were also prepared, using a ferrocenylhydrosilane as a substrate for the coupling, which enabled the preparation of ferrocene-containing 
polysilylethers. The precatalyst $\left[\left[\mathrm{Ba}\left\{\mathrm{N}\left(\mathrm{SiMe}_{3}\right)_{2}\right\}_{2} \cdot(\text { thf })_{2}\right]\right.$ was hence used in the synthesis of a range ferrocene-containing polysilylethers from ferrocenylhydrosilanes and diols (Figure 22c-d). The hydrolytic stability of these polymers allowed molecular weight estimation by GPC, of which some were found to have molecular weights of over 20,000 Da.

\section{Miscellaneous catalysis}

The enantioselective Friedel-Crafts-type alkylation of indoles has been reported using an in-situ generated chiral barium catalyst. ${ }^{[129]}$ Mixing $\left[\mathrm{Ba}\left\{\mu-\mathrm{N}\left(\mathrm{SiMe}_{3}\right)_{2}\right\}\left\{\mathrm{N}\left(\mathrm{SiMe}_{3}\right)_{2}\right\}\right]_{2}$ and the chiral $\left\{\mathrm{BINOL}^{\mathrm{SiPh} 3}\right\} \mathrm{H}_{2}$ proligand substituted in 3 and 3' positions by bulky $\mathrm{SiPh}_{3}$ groups, prior to the addition of an indole and a Michael acceptor, generated the desired indoles substituted at the 3-position in yields up to $97 \%$ and $e e$ 's up to $96 \%$ (Figure 23, top). A mechanism was proposed in which the coordinated the coordinated indolide is attacked at the $\beta$-carbon by the alkene of the $\beta$-unsaturated ketone, but it was not substantiated. The authors found different indole derivatives worked well, although 2-methylindole reacted much slower with only low ee's which was attributed to steric hindrance at the 2-position.<smiles></smiles><smiles>O=C(Br)/C=C/[17Br]</smiles>

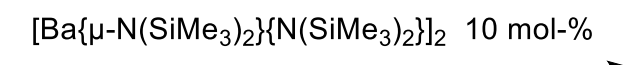
$\left\{\right.$ BINOL $\left.^{\mathrm{SiPh} 3}\right\} \mathrm{H}_{2} 10 \mathrm{~mol}-\%$

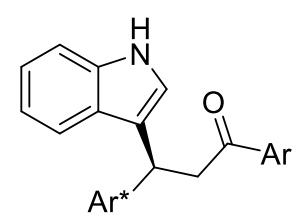

16 examples up to $97 \%$ yield up to $96 \%$ ee

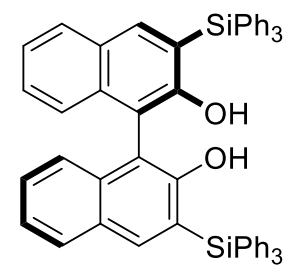

$\left\{\mathrm{BINOL}{ }^{\mathrm{SiPh} 3}\right\} \mathrm{H}_{2}$

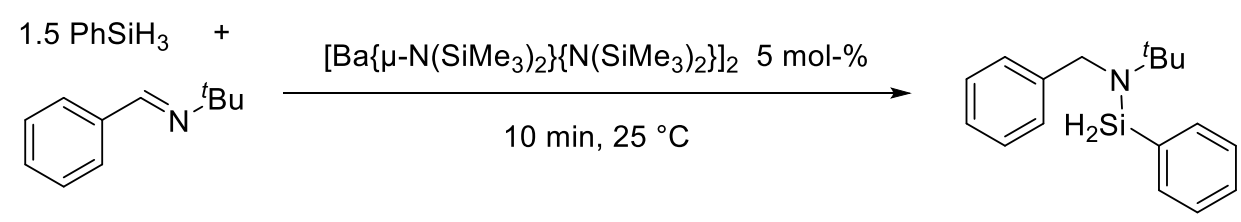

Figure 23. Barium-catalysed enantioselective formation of 3 -substituted indoles (top), ${ }^{[129]}$ and hydrosilylation of imines (bottom). ${ }^{[61 b]}$

The amides $\left[\mathrm{Ae}\left\{\mu-\mathrm{N}\left(\mathrm{SiMe}_{3}\right)_{2}\right\}\left\{\mathrm{N}\left(\mathrm{SiMe}_{3}\right)_{2}\right\}\right]_{2}$ and their potassium derivative $\left[\mathrm{KN}\left(\mathrm{SiMe}_{3}\right)_{2}\right]$ were used to catalyse the hydrosilylation of ketimines and aldimines with $\mathrm{PhSiH}_{3}$ (Figure 23, bottom). ${ }^{[61 \mathrm{~b}]}$ The reactions proceeded at $25-60{ }^{\circ} \mathrm{C}$, and the activity of the precatalysts increased according to $\mathrm{K}<\mathrm{Ca}<\mathrm{Sr}<$ Ba. The amino-alkyl complexes $\left[\{\mathrm{DMAT}\}_{2} \mathrm{Ae} \cdot(\text { thf })_{2}\right](\mathrm{DMAT}=2$-dimethylamino- $\alpha$-trimethylsilylbenzyl) were also utilised for $\mathrm{Ae}=\mathrm{Ca}$ and $\mathrm{Sr}^{[130]}$ They showed greater efficacy than the simple metal-amides; however, the barium derivative was not tested, presumably owing to synthetic difficulties in preparing this 
complex. Overall, the best precatalysts were $\left[\operatorname{Sr}\{\mathrm{DMAT}\}_{2} \cdot \operatorname{thf}_{2}\right]$ and $\left[\mathrm{Ba}\left\{\mu-\mathrm{N}\left(\mathrm{SiMe}_{3}\right)_{2}\right\}\left\{\mathrm{N}\left(\mathrm{SiMe}_{3}\right)_{2}\right\}\right]_{2}$. Concerning the substrates, the fastest reaction rates were found for imines with $\mathrm{N}$-alkyl and C-aryl substituents, e.g. $\mathrm{PhC}(\mathrm{H})=\mathrm{N}^{t} \mathrm{Bu}$. Functional group tolerance was good, notably through introduction of substituents in para position of the phenyl ring. Convincing data and DFT analysis agreed with a three-step catalytic manifold involving first the generation of a metal hydride active species, followed by addition of the metal hydride to the imine to give an amide intermediate, and cleavage of the metal-amide bond by $\mathrm{PhSiH}_{3}$ to release the hydrosilylation product and regenerate of the catalytically active metal hydride.

\section{Conclusion and perspectives}

As outlined in the preceding, there can be little doubt that the molecular chemistry of barium has enjoyed spectacular progress in the last few years. The design of increasingly sophisticated ligand frameworks combined to the deliberate introduction of secondary, and yet vital, non-covalent interactions has allowed for the preparation of hitherto unknown complexes by overcoming the limitations inherent to this metal. Significant advances in the field have been made possible through improved control of the coordination

sphere and taming of the kinetic lability that characterise barium complexes. These breakthroughs give synthetic organometallic and organic chemists every reason to be optimistic about the future of well-defined barium complexes, whether for the construction of new bonding motifs or for applications in homogenous catalysis. It now seems fair to assume that the limits to the different structural patterns that can be built will primarily be set by the imagination of the daring chemists that will tackle the field. Yet, it also appears equally clear that for barium to become more useful, the range of applications will have to outgrow its current applications in molecular catalysis. In the context of global sustainability, novel atom-efficient catalysed reactions that produce high value chemicals must be devised where barium will again have to opportunity to thrive. Besides, the stoichiometric and sub-catalytic reactivity of barium complexes towards small molecules remains seldom explored. This certainly constitutes an area from which many exciting discoveries should be expected in the coming years.

\section{References}

[1] S. Harder, Chem. Rev. 2010, 110, 3852.

[2] A. G. M. Barrett, M. R. Crimmin, M. S. Hill, P. A. Procopiou, Proc. R. Soc. A, 2010, 466, 927.

[3] M. S. Hill, D. J. Liptrot, C. Weetman, Chem. Soc. Rev. 2016, 45, 972.

[4] S. Harder in Alkaline Earth Metal Compounds: Oddities and Applications, Springer-Verlag, Heidelberg, 2013.

[5] S. Harder in Early Main Group Metal Catalysis, Wiley-VCH, Weinheim, 2020.

[6] K. Fromm, Coord. Chem. Rev. 2020, 408, 213193. 
[7] a) D. L. Schulz, T. J. Marks, Adv. Mater. 1994, 6, 719; b) J. M. Zhang, B. W. Wessels, D. S. Richeson, T. J. Marks, D. C. DeGroot, C. R. Kannewurf, J. Appl. Phys. 1991, 69, 2743; c) R. L. Nigro, R. G. Toro, M. R. Catalano, G. Malandrino, I. L. Fragala, P. Fiorenza, V. Raineri, ECS Trans. 2009, 25, 135; d) P. P. Sahoo, T. N. Guru Row, Inorg. Chem. 2010, 49, 10013.

[8] A. C. Jones, H. C. Aspinall, P. R. Chalker, Surf. Coat. Technol. 2007, 201, 9046

[9] a) W. A. Wojtczak, P. F. Fleig, M. J. Hampden-Smith, Adv. Organomet. Chem. 1996, 40, 215; b) J. Brooks, H. O. Davies, T. J. Leedham, A. C. Jones, A. Steiner, Chem. Vap. Deposition, 2000, 6, 66.

[10] S. M. George, B. K. Park, C. G. Kim, T-M. Chung, Eur. J. Inorg. Chem. 2014, 2002.

[11] M. J. Saly, M. J. Heeg, C. H. Winter, Inorg. Chem. 2009, 48, 5303.

[12] P. Patnaik in Handbook of Inorganic Chemicals, McGraw-Hill, 2003.

[13] J. W. Moore in Inorganic Contaminants of Surface Waters, Research and Monitoring Priorities. Springer-Verlag, New-York, 1991.

[14] B. S. Bhoelan, C. H. Stevering, V. D. Bogg, V. D. Heyden, Clin. Toxicol. 2014, 52, 584.

[15] I. R. McNeill, K. Z. Isoardi, Toxicol. 2019, 3, 88.

[16] C. Lambert, P. v. R. Schleyer, Angew. Chem. Int. Ed. 1994, 33, 1129.

[17] R. D. Shannon, Acta Crystallogr. 1976, A32, 751.

[18] A. S. S. Wilson, M. S. Hill, M. F. Mahon, C. Dinoi, L. Maron, Science 2017, 358, 1168.

[19] S. Harder, J. Brettar, Angew. Chem. Int. Ed. 2006, 45, 3474.

[20] S. Nembenna, H. W. Roesky, S. Nagendran, A. Hofmeister, J. Magull, P-J. Wilbrandt, M. Hahn, Angew. Chem. Int. Ed. 2007, 46, 2512.

[21] A. G. Avent, M. R. Crimmin, M. S. Hill, P. B. Hitchcock, Dalton Trans. 2005, 278.

[22] W. D. Buchanan, D. G. Allis, K. Ruhlandt-Senge, Chem. Commun. 2010, 46, 4449.

[23] Y. Sarazin, J.-F. Carpentier in Noncovalent Interactions in Catalysis, Eds. K. T. Mahmudov, M. N. Kopylovich, M. F. C. Guedes da Silva, A. J. L. Pombeiro, Royal Society of Chemistry, London, 2019.

[24] M. Gillett-Kunnath, W. Teng, W. Vargas, K. Ruhlandt-Senge, Inorg. Chem. 2005, 44, 4862.

[25] E. Le Coz, V. Dorcet, T. Roisnel, S. Tobisch, J.-F. Carpentier, Y. Sarazin, Angew. Chem. Int. Ed. 2018, 57,11747

[26] B. A. Vaartstra, J. C. Huffman, W. E. Streib, K. G. Caulton, Inorg. Chem. 1991, 30, 121.

[27] S. Krieck, P. Schüler, H. Görls, M. Westerhausen, Inorg. Chem. 2018, 57, 13937.

[28] P. Schüler, H. Görls, M. Westerhausen, S. Krieck, Dalton Trans. 2019, 48, 8966.

[29] T. X. Gentner, B. Rösch, K. Thum, J. Langer, G. Ballmann, J. Pahl, W. A. Donaubauer, F. Hampel, S. Harder, Organometallics 2019, 38, 2485. 
[30] Y. Sarazin, J.-F. Carpentier, Chem. Rec. 2016, 16, 2482.

[31] a) I. D. Brown, R. D. Shannon, Acta Crystallogr., Sect. A: Cryst. Phys., Diffr., Theor. Gen. Crystallogr. 1973, 29, 266; b) I. D. Brown and D. Altermatt, Acta Crystallogr., Sect. B: Struct. Sci. 1985, 41, 244; c) G. Donnay, R. Allmann, Am. Mineral. 1970, 55, 1003; d) I. D. Brown, K. K. Wu, Acta Crystallogr., Sect. B: Struct. Crystallogr. Cryst. Chem. 1976, 32, 1957; e) N. E. Brese, M. O’Keeffe, Acta Crystallogr., Sect. B: Struct. Sci. 1991, 47, 192; f) M. O’Keefe, N. E. Brese, J. Am. Chem. Soc. 1991, 113, 3226.

[32] a) O. Michel, K. W. Törnroos, C. Maichle-Mössmer, R. Anwander. Chem. Eur. J. 2011, 17, 4964;

b) O. Michel, K. W. Törnroos, C. Maichle-Mössmer, R. Anwander, Eur. J. Inorg. Chem. 2012, 44.

[33] M. Wiesinger, B. Maitland, C. Färber, G. Ballmann, C. Fischer, H. Elsen, S. Harder, Angew. Chem. Int. Ed. 2017, 56, 16654.

[34] a) S. O. Hauber, F. Lissner, G. B. Deacon, M. Niemeyer, Angew. Chem. Int. Ed. 2005, 44, 5871; b) H. Sul Lee, M. Niemeyer, Inorg. Chem. 2010, 49, 730.

[35] G. J. Moxey, A. J. Blake, W. Lewis, D. L. Kays, Eur. J. Inorg. Chem. 2015, 5892.

[36] X. Shi, J. Cheng, Dalton Trans. 2019, 48, 8565.

[37] M. Gärtner, H. Görls, M. Westerhausen, Dalton Trans. 2008, 48, 1574

[38] M. D. Anker, M. Arrowsmith, R. L. Arrowsmith, M. S. Hill, M. F. Mahon, Inorg. Chem. 2017, 56, 5976.

[39] H. Roueindeji, A. Ratsifitahina, T. Roisnel, V. Dorcet, S. Kahlal, J.-Y. Saillard, J.-F. Carpentier, Y. Sarazin, Chem. Eur. J. 2019, 25, 8854.

[40] a) A. Causero, G. Ballmann, J. Pahl, C. Farber, J. Intermann, S. Harder, Dalton Trans. 2017, 46, 1822; b) W. Scherer, P. Sirsch, M. Grosche, M. Spiegler, S. A. Mason, M. G. Gardiner, Chem. Commun. 2001, 2072; c) M. Westerhausen, W. Schwarz, Z. Anorg. Allg. Chem. 1991, 606, 177; M. Westerhausen, W. Schwarz, Z. Anorg. Allg. Chem. 1991, 604, 127.

[41] a) L. J. Procopio, P. J. Carroll, D. H. Berry, J. Am. Chem. Soc. 1994, 116, 177; b) W. A. Herrmann, J. Eppinger, M. Spiegler, O. Runte, R. Anwander, Organometallics, 1997, 16, 1813; c) R. Anwander, O. Runte, J. Eppinger, G. Gerstberger, E. Herdtweck, M. J. Spiegler, J. Chem. Soc., Dalton Trans. 1998, 847; d) W. Hieringer, J. Eppinger, R. Anwander, W. A. Herrmann, J. Am. Chem. Soc. 2000, 122, 11983; e) H. J. Yuen, T. J. Marks, Organometallics, 2008, 27, 155.

[42] Y. Sarazin, D. Roşca, V. Poirier, T. Roisnel, A. Silvestru, L. Maron, J.-F. Carpentier, Organometallics, 2010, 29, 6569.

[43] B. Liu, T. Roisnel, J.-F. Carpentier, Y. Sarazin. Angew. Chem. Int. Ed. 2012, 51, 4943.

[44] E. Le Coz, H. Roueindeji, T. Roisnel, V. Dorcet, J.-F. Carpentier Y. Sarazin, Dalton Trans. 2019, $48,9173$. 
[45] E. Le Coz, H. Roueindeji, V. Dorcet, T. Roisnel, J.-F. Carpentier, Y. Sarazin, Dalton Trans. 2019, 48,5500 .

[46] a). E. Mulvey, F. Mongin, M. Uchiyama, Y. Kondo, Angew. Chem. Int. Ed. 2007, 46, 3802; b) B. Haag, M. Mosrin, H. Ila, V. Malakhov, P. Knochel, Angew. Chem. Int. Ed. 2011, 50, 9794; c) A. Harrison-Marchand, F. Mongin, Chem. Rev. 2013, 113, 7470; d) F. Mongin, A. HarrisonMarchand, Chem. Rev. 2013, 113, 7563; e) D. Tilly, F. Chevallier, F. Mongin, P. C. Gros, Chem. Rev. 2014, 114, 1207; e) D. S. Ziegler, B. Wie, P. Knochel, Chem. Eur. J. 2019, 25, 2695.

[47] A. M. Johns, S. C. Chmely, T. P. Hanusa, Inorg. Chem. 2009, 48, 1380.

[48] a) B. De Groof, M. Van Beylen, M. Szwarc, Macromolecules, 1975, 8, 396; b) B. De Groof, W. Mortier, M. Van Beylen, M. Szwarc. Macromolecules 1977, 10, 598.

[49] A. Weeber, S. Harder, H. H. Brintzinger, K. Knoll, Organometallics, 2000, 19, 1325

[50] K. Izod, P. G. Waddell, Organometallics, 2015, 34, 2726

[51] M. R. Crimmin, A. G. M. Barrett, M. S. Hill, D. J. MacDougall, M. F. Mahon, P. A. Procopiou, Chem. Eur. J. 2008, 14, 11292.

[52] a) J. S. Alexander, K. Ruhlandt-Senge, Chem. Eur. J. 2004, 10, 1274; b) M. A. Guino-o, A. Torvisco, W. Teng, K. Ruhlandt-Senge, Inorg. Chim. Acta. 2012, 389, 122.

[53] P. M. Chapple, Y. Sarazin, private communication.

[54] B. Liu, T. Roisnel, J.-F. Carpentier, Y. Sarazin, Chem. Eur. J. 2013, 19, 13445

[55] X. Shi, G. Qin, Y. Wang, L. Zhao, Z. Liu, J. Cheng, Angew. Chem. Int. Ed. 2019, 58, 4356.

[56] O. Michel, S. König, K. W. Törnroos, C. Maichle-Mössmer, R. Anwander, Chem. Eur. J. 2011, 17, 11857.

[57] O. Michel, K. Yamamoto, H. Tsurugi, C. Maichle-Mössmer, K. W. Törnroos, K. Mashima, R. Anwander, Organometallics 2011, 30, 3818.

[58] a) T. P. Hanusa, Chem. Rev. 1993, 93, 1023; b) M. L. Hays, T.P. Hanusa, Adv. Organomet. Chem. 1996, 40, 117; c) P. Jutzi, N. Burford, Chem. Rev. 1999, 99, 969.

[59] a) D. C. Green, U. Englich, K. Ruhlandt-Senge, Angew. Chem. Int. Ed. 1999, 38, 354; b) M. A. Guino-o, J. S. Alexander, M. L. McKee, H. Hope, U. B. Englich, K. Ruhlandt-Senge, Chem. Eur. J. 2009, 15, 11842.

[60] M. Westerhausen, Inorg. Chem. 1991, 30, 96.

[61] a) M. R. Crimmin, A. G. M. Barrett, M. S. Hill, P. B. Hitchcock, P. A. Procopiou, Organometallics 2008, 27, 497; b) H. Elsen, C. Fischer, C. Knüpfer, A. Escalona, S. Harder, Chem. Eur. J. 2019, $25,16141$.

[62] H. Bauer, M. Alonso, C. Färber, H. Elsen, J. Pahl, A. Causero, G. Ballmann, F. De Proft, S. Harder, Nat. Catal. 2018, 1, 40. 
[63] H. Bauer, M. Alonso, C. Fischer, B. Rösch, H. Elsen, S. Harder, Angew. Chem. Int. Ed. 2018, 57, 15177

[64] C. Bellini, J.-F. Carpentier, S. Tobisch, Y. Sarazin, Angew. Chem. Int. Ed. 2015, 54, 7679.

[65] M. S. Hill, M. Hodgson, D. J. Liptrot, M. F. Mahon, Dalton Trans. 2011, 40, 7783.

[66] a) M. Westerhausen, Coord. Chem. Rev. 1998, 176, 157; b) A. Torvisco, A. Y. O'Brien, K. Ruhlandt-Senge, Coord. Chem. Rev. 2011, 255, 1268.

[67] A. G. M. Barrett, M. R. Crimmin, M. S. Hill, G. Kociok-Köhn, D. J. MacDougall, M. F. Mahon, P. A. Procopiou, Organometallics, 2008, 27, 3939.

[68] C. Müller, S. Krieck, H. Görls, M. Westerhausen, Eur. J. Inorg. Chem. 2016, 4637.

[69] Z. R. Turner, J.-C. Buffet, Dalton Trans. 2015, 44, 12985

[70] R. P. Davies, Inorg. Chem. Commun. 2000, 3, 13.

[71] a) M. Westerhausen, M. Hartmann, N. Makropoulos, B. Wieneke, M. Wieneke, W. Schwarz, D. Stalke, Z. Naturforsch. B: Chem. Sci. 1998, 117; b) F. M. Younis, H. Görls, S. Krieck, M. Westerhausen, Z. Anorg. Allg. Chem. 2013, 19; c) C. Laurence, J.-F. Gal, Lewis Basicity and Affinity Scales: Data and Measurement, Wiley, Chichester, UK, 2010, p. 103.

[72] G. B. Deacon, C. M. Forsyth, P. C. Junk, J. Organomet. Chem. 2000, 607, 112.

[73] a) G. B. Deacon, P. C. Junk, G. J. Moxey, New J. Chem. 2010, 34, 1731; b) T. J. Boyle, L. A. M. Steele, A. Saad, Inorg. Chim. Acta. 2013, 394, 259.

[74] K. F. Tesh, T. P. Hanusa, J. C. Huffman, Inorg. Chem. 1992, 31, 5572.

[75] B. Liu, T. Roisnel, Y. Sarazin, Inorg. Chim. Acta. 2012, 380, 2.

[76] G. B. Deacon, P. C. Junk, G. J. Moxey, M. Guino-o, K. Ruhlandt-Senge, Dalton Trans. 2009, 4878.

[77] T. Heidemann, S. Mathur, Inorg. Chem. 2017, 56, 234.

[78] W. D. Buchanan, M. A. Guino-o, K. Ruhlandt-Senge, Inorg. Chem. 2010, 49, 7144.

[79] a) Y. Chi, S. Ranjan, P-W. Chung, H-Y. Hsieh, S-M. Peng, G-H. Lee, Inorg. Chim. Acta. 2002, 334, 172; b) Y. Chi, S. Ranjan, T-Y. Chou, C-S. Liu, S-M. Peng, G-H. Lee, J. Chem. Soc., Dalton Trans. 2001, 2462.

[80] K. G. Caulton, M. H. Chisholm, S. R. Drake, W. E. Streib, Angew. Chem. Int. Ed. 1990, 29, 1483.

[81] J. A. Darr, S. R. Drake, D. J. Williams, A. M. Z. Slawin, J. Chem. Soc. Chem. Commun. 1993, 866.

[82] W. A. Wojtczak, M. J. Hampden-Smith, E. N. Duesler, Inorg. Chem. 1996, 35, 6638.

[83] S. R. Drake, W. E. Streib, K. Folting, M. H. Chisholm, K. G. Caulton, Inorg. Chem. 1992, 31, 3205.

[84] E. Le Coz, S. Kahlal, J.-Y. Saillard, T. Roisnel, V. Dorcet, J.-F. Carpentier, Y. Sarazin, Chem. Eur. J. 2019, 25, 13509.

[85] E. Le Coz, Z. Zhang, T. Roisnel, L. Cavallo, L. Falivene, J.-F. Carpentier, Y. Sarazin, Chem. Eur. J. 2020, 26, 3535 
[86] a) C. Ruspic, S. Nembenna, A. Hofmeister, J. Magull, S. Harder, H. W. Roesky, J. Am. Chem. Soc. 2006, 128, 15000; b) S. Sarish, S. Nembenna, S. Nagendran, H. W. Roesky, A. Pal, R. HerbstIrmer, A. Ringe, J. Magull, Inorg. Chem. 2008, 47, 5971.

[87] S. Pillai Sarish, H. W. Roesky, M. John, A. Ringe, J. Magull, Chem. Commun. 2009, 2390.

[88] M. R. Crimmin, A. G. M. Barrett, M. S. Hill, P. B. Hitchcock, P. A. Procopiou, Organometallics, 2007, 26, 2953.

[89] a) W. Clegg, S. J. Coles, E. K. Cope, F. S. Mair, Angew. Chem. Int. Ed. 1998, 37, 796; b) H. M. El-Kaderi, M. J. Heeg, C. H. Winter, Organometallics 2004, 23, 4995.

[90] M. H. Chisholm, J. Gallucci, K. Phomphrai, Chem. Commun. 2003, 48.

[91] B. Liu, T. Roisnel, J.-F. Carpentier, Y. Sarazin, Chem. Eur. J. 2013, 19, 2784.

[92] C. Bellini, C. Orione, J.-F. Carpentier, Y. Sarazin, Angew. Chem. Int. Ed. 2016, 55, 3744.

[93] G. Ballmann, B. Rösch, S. Harder, Eur. J. Inorg. Chem. 2019, 3683.

[94] G. Ballmann, S. Grams, H. Elsen, S. Harder, Organometallics 2019, 38, 2824.

[95] a) P. M. Chapple, S. Kahlal, J. Cartron, T. Roisnel, V. Dorcet, M. Cordier, J.-Y. Saillard, J.-F. Carpentier, Y. Sarazin, Angew. Chem. Int. Ed. 2020, 59, 9120; b) P. M. Chapple, M. Cordier, V. Dorcet, T. Roisnel, J.-F. Carpentier, Y. Sarazin, manuscript submitted.

[96] S. P. Sarish, H. W. Roesky, M. John, A. Ringe, J. Magull, Chem. Commun. 2009, 2390.

[97] W. Teng, U. Englich, K. Ruhlandt-Senge, Angew. Chem. Int. Ed. 2003, 42, 3661.

[98] a) M. S. Hill, P. B. Hitchcock, Chem. Commun. 2003, 1758; b) T. K. Panda, A. Zulys, M. T. Gamer, P. W. Roesky, J. Organomet. Chem. 2005, 690, 5078; c) S. A. Ahmed, M. S. Hill, P. B. Hitchcock, Organometallics 2006, 25, 394; d) L. Orzechowski, S. Harder, Organometallics 2007, 26, 5501.

[99] A. Causero, G. Ballmann, J. Pahl, H. Zijlstra, C. Färber and S. Harder, Organometallics 2016, 35, 3350.

[100] M. H. Chisholm, J. C. Gallucci, G. Yaman, Dalton Trans. 2009, 368.

[101] O. Michel, H. M. Dietrich, R. Litlabø, K. W. Törnroos, C. Maichle-Mössmer, R. Anwander, Organometallics, 2012, 31, 3119.

[102] X. Shi, C. Hou, C. Zhou, Y. Song, J. Cheng, Angew. Chem. Int. Ed. 2017, 56, 16650.

[103] a) S. Harder, Chem. Commun. 2012, 48, 11165; b) D. Mukherjee, J. Okuda, Angew. Chem. Int. Ed. 2018, 57, 1458; c) D. Mukherjee, D. Schuhknecht, J. Okuda, Angew. Chem. Int. Ed. 2018, 57, 9590.

[104] a) B. Maitland, M. Wiesinger, J. Langer, G. Ballmann, J. Pahl, H. Elsen, C. Färber, S. Harder, Angew. Chem. Int. Ed. 2017, 56, 11880; b) D. Mukherjee, T. Höllerhage, V. Leich, T. P. Spaniol, U. Englert, L. Maron, J. Okuda, J. Am. Chem. Soc. 2018, 140, 3403.

[105] M. Arrowsmith, A. Heath, M. S. Hill, P. B. Hitchcock, G. Kociok-Köhn, Organometallics 2009, 28,4550 . 
[106] CSD version 5.41, November 2019.

[107] Y. Sarazin. B. Liu, T. Roisnel, L. Maron, J.-F. Carpentier, J. Am. Chem. Soc. 2011, 133, 9069.

[108] T. K. Panda, H. Kaneko, O. Michel, K. Pal, H. Tsurugi, K. W. Törnroos, R. Anwander, Kazushi Mashima, Organometallics 2012, 31, 3178.

[109] V. Lorenz, C. G. Hrib, D. Grote, L. Hilfert, M. Krasnopolski, F. T. Edelmann, Organometallics 2013, 32, 4636.

[110] O. Michel, H. Kaneko, H. Tsurugi, K. Yamamoto, K. W. Törnroos, R. Anwander, K. Mashima, Eur. J. Inorg. Chem. 2012, 998.

[111] For a more detailed and very accurate introduction to the specificities Ae-mediated catalysis, the reader is referred to: M. S. Hill, Miscellaneous reactions in Early Main Group Metal Catalysis, Ed. S. Harder, Wiley-VCH, Weinheim, 2020; chapter 13, pp. 347-372.

[112] R. Waterman, Organometallics, 2013, 32, 24, 7249-7263.

[113] M. R. Crimmin, M. Arrowsmith, A. G. M. Barrett, I. J. Casely, M. S. Hill, P. A. Procopiou, J. Am. Chem. Soc. 2009, 131, 9670.

[114] a) C. A. Wheaton, P. G. Hayes, B. J. Ireland, Dalton Trans. 2009, 4832; b) N. Ajellal, J.-F. Carpentier, C. Guillaume, S. M. Guillaume, M. Hélou, V. Poirier, Y. Sarazin, A. Trifonov, Dalton Trans. 2010, 39, 8363; c) M. Arrowsmith, Enc. Inorg. Bioinorg. Chem. 2015, 1.

[115] M. R. Crimmin, I. J. Casely, M. S. Hill, J. Am. Chem. Soc. 2005, 127, 2042.

[116] M. Arrowsmith, M. R. Crimmin, A. G. M. Barrett, M. S. Hill, G. Kociok-Köhn, P. A. Procopiou, Organometallics, 2011, 30, 1493.

[117] B. Freitag, P. Stegner, K. Thum, C. A. Fischer, S. Harder, Eur. J. Inorg. Chem. 2018, 1938.

[118] A. G. M. Barrett, C. Brinkmann, M. R. Crimmin, M. S. Hill, P. Hunt, P. A. Procopiou, J. Am. Chem. Soc. 2009, 131, 12906.

[119] C. Brinkmann, A. G. M. Barrett, M. S. Hill, P. A. Procopiou, J. Am. Chem. Soc. 2012, 134, 2193.

[120] S. Tobisch, Chem. Eur. J. 2014, 20, 8988.

[121] M. He, M. T. Gamer, P. W. Roesky, Organometallics 2016, 35, 2638.

[122] J. Spielmann, F. Buch, S. Harder, Angew. Chem. Int. Ed. 2008, 47, 9434.

[123] J. Martin, C. Knüpfer, J. Eyselein, C. Färber, S. Grams, J. Langer, K. Thum, M. Wiesinger, S. Harder, Angew. Chem. Int. Ed. 2020, 59, 9102.

[124] H. Bauer, K. Thum, M. Alonso, C. Fischer, S. Harder, Angew. Chem. Int. Ed. 2019, 58, 4248.

[125] a) J. F. Dunne, S. R. Neal, J. Engelkemier, A. Ellern, A. D. Sadow, J. Am. Chem. Soc. 2011, 133, 16782; b) M. S. Hill, D. J. Liptrot, D. J. MacDougall, M. F. Mahon T. P. Robinson, Chem. Sci. 2013, 4, 4212.

[126] C. Bellini, V. Dorcet, J.-F. Carpentier, S. Tobisch, Y. Sarazin, Chem. Eur. J. 2016, 22, 4564. 
[127] L. J. Morris, G. R. Whittell, J.-C. Eloi, M. F. Mahon, F. Marken, I. Manners, M. S. Hill, Organometallics, 2019, 38, 3629.

[128] C. Bellini, T. Roisnel, J.-F. Carpentier, S. Tobisch, Y. Sarazin, Chem. Eur. J. 2016, 22, 15733.

[129] T. Tsubogo, Y. Kano, Y. Yamashita, S. Kobayashi, Chem. Asian J. 2010, 5, 1974

[130] F. Feil, S. Harder, Organometallics 2001, 20, 4616. 
For the Table of Contents only

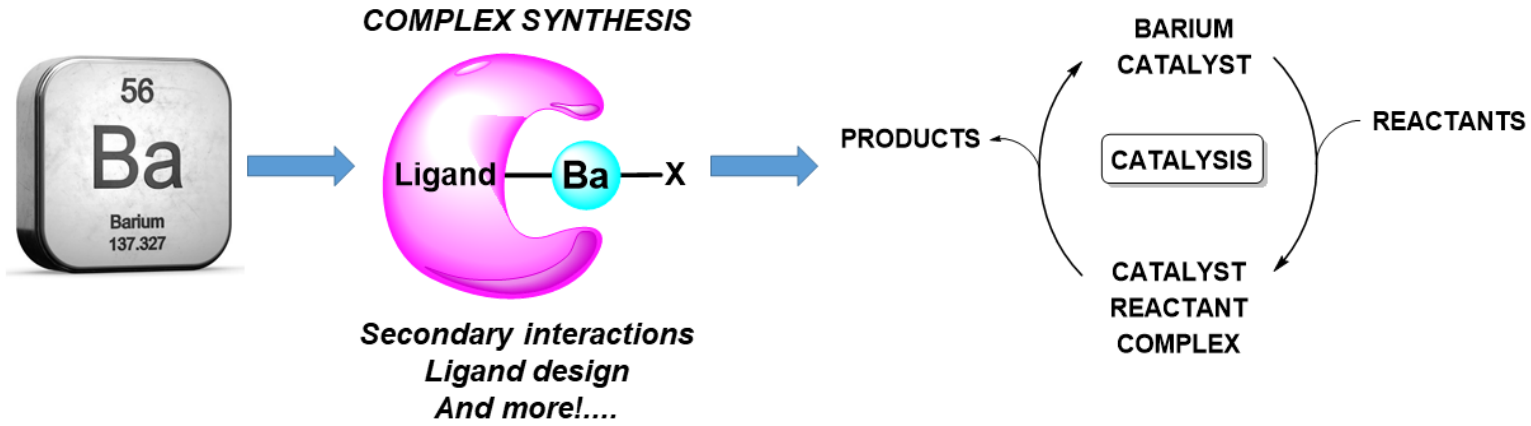

An up-to-date survey of the recent progress in the molecular chemistry of barium is presented. It covers the synthesis of well-defined, soluble barium complexes, and their performances as homogeneous catalysts in a variety of reactions such as hydroelementations and dehydrocouplings.

Key Topic: Barium molecular complexes - Catalysis 


\section{Author biographies}

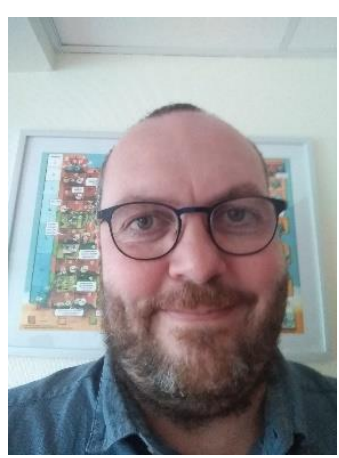

Dr. Yann Sarazin, born in 1977, gained his Ph.D. in macromolecular and coordination chemistry in 2004 from the University of East Anglia, UK, under the guidance of Prof. M. Bochmann. After a 3 year postdoc, still at UEA, studying main-group cations, he returned to France in 2007 for a 1 year stint as a postdoc for Total Petrochemicals. He has then been a fulltime CNRS Researcher at the University of Rennes 1 since 2008. His main current research interests include the fundamental organometallic chemistry of main group metals, most notably alkaline earths and tetrel elements, and its applications in the catalysis of polymerisation and fine chemicals reactions, with an emphasis on the study of operative mechanisms. He has published over 90 papers, patents, and book chapters in these fields.

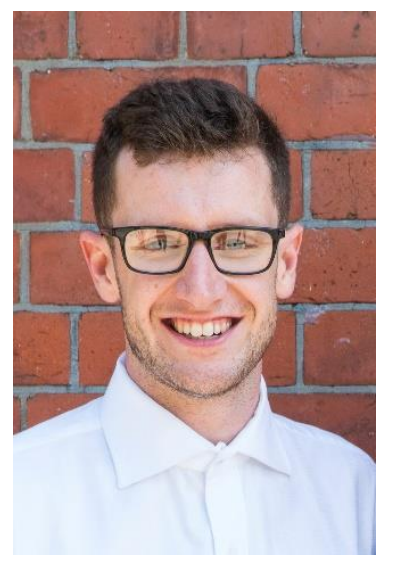

Peter M. Chapple, received his B.S (and B.Com) from Victoria University of Wellington (New Zealand) in 2016. During this time he started working in the lab of J. R. Fulton, obtaining his M.Sc in 2018. He is currently a PhD student at the University of Rennes 1, under the supervision of Dr. Yann Sarazin and Prof. J-F. Carpentier. His current research is focused on the development of new molecular heavier alkaline earth catalysts for the synthesis of main group element containing polymers. 